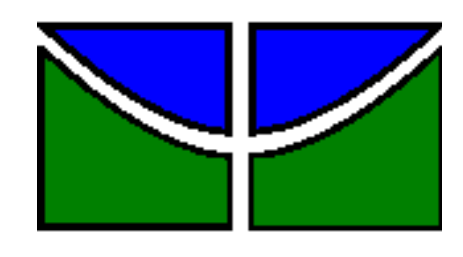

UNIVERSIDADE DE BRASÍLIA

Faculdade de Educação - UAB/UnB/ MEC/SECAD

Curso de Especialização em Educação na Diversidade e Cidadania, com Ênfase em EJA

Margareth Matias Porfírio Machado

Rafael Vieira de Araújo

\title{
O MUNDO DO TRABALHO E A EDUCAÇÃO DE ADOLESCENTES, JOVENS E ADULTOS NA REDE MUNICIPAL DE GOIÂNIA: \\ Possibilidades e desafios
}

Goiânia, GO

Junho/2010 
UNIVERSIDADE DE BRASÍLIA

Faculdade de Educação - UAB/UnB/ MEC/SECAD

Curso de Especialização em Educação na Diversidade e Cidadania,

com Ênfase em EJA

\title{
O MUNDO DO TRABALHO E A EDUCAÇÃO DE ADOLESCENTES, JOVENS E ADULTOS NA REDE MUNICIPAL DE GOIÂNIA: \\ Possibilidades e desafios
}

\author{
Margareth Matias Porfírio Machado \\ Rafael Vieira de Araújo
}

Projeto de Intervenção Local apresentado para obtenção do título de especialista da PósGraduação Lato Sensu em Educação e Diversidade na Cidadania com Ênfase na Educação de Jovens e Adultos pela Universidade de Brasília (UnB) no âmbito da Universidade Aberta do Brasil (UAB), sendo alunos da Turma "J", sob a orientação da Profa $\mathrm{Ms}^{\mathrm{a}}$. Juliana Alves de Araújo Bottechia e Prof ${ }^{\mathrm{a}}$. Drª . Maria Margarida Machado.

Goiânia, GO

Junho/2010 
ARAÚJO, Rafael Vieira de; MACHADO, Margareth Matias Porfírio.

O mundo do trabalho e a educação de adolescentes, jovens e adultos na Rede Municipal de Goiânia: Possibilidades e desafios. / - Goiânia - GO: UnB, 2010. $128 f$.

Orientadora: Prof ${ }^{a}$. Ms ${ }^{a}$. Juliana Alves de Araújo Bottechia e Prof ${ }^{a}$. Dr ${ }^{a}$. Maria Margarida Machado.

Projeto de Intervenção Local - Universidade de Brasília, Faculdade de Educação

$\mathrm{UAB} / \mathrm{UnB} / M E C / S E C A D$, Curso de Especialização em Educação na Diversidade e Cidadania, com Ênfase em EJA.
1. Escola.
2. Educando.
3. EJA

I. Título. O mundo do trabalho e a educação de adolescentes, jovens e adultos na Rede Municipal de Goiânia: Possibilidades e desafios. 


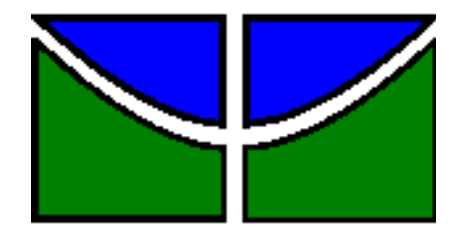

UNIVERSIDADE DE BRASÍLIA

Faculdade de Educação - UAB/UnB/ MEC/SECAD

Curso de Especialização em Educação na Diversidade e Cidadania, com Ênfase em EJA

Margareth Matias Porfírio Machado

Rafael Vieira de Araújo

\section{O MUNDO DO TRABALHO E A EDUCAÇÃO DE ADOLESCENTES, JOVENS E ADULTOS NA REDE MUNICIPAL DE GOIÂNIA: \\ Possibilidades e desafios}

Trabalho de conclusão do Curso de Especialização em Educação na Diversidade e Cidadania, com Ênfase em EJA, como parte dos requisitos necessários para obtenção do grau de Especialista na Educação de Jovens e Adultos

\section{Prof ${ }^{\mathrm{a}}$. Dra . Maria Margarida Machado \\ Professora Orientadora}

\section{Prof ${ }^{a}$. Ms a Juliana Alves de Araújo Bottechia \\ Tutora Orientadora}

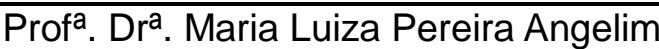

Avaliadora Externa

GOIÂNIA, GO

Junho/2010 
Dedicamos aos nossos familiares, amigos e a tutora presencial Claúdia 


\section{AGRADECIMENTOS}

Para cumprir as metas, os objetivos e conquistas na trajetória da vida é preciso que um coletivo de pessoas se una para que as dificuldades e obstáculos sejam superados.

São esses amigos (as) que com muita sabedoria promove nossa educação desde 0 nascimento tratando-nos com princípios humanos de solidariedade, amor, cooperação, honra, dignidade, determinação, honestidade, que, às vezes, a ciência, o mundo ou o próprio homem ficam cegos perante esses princípios.

Estamos lisonjeados e privilegiados perante nosso grupo familiar; agradeço aos nossos pais que são sujeitos fundamentais para nossa formação como pessoa e profissional. Foram muitas renúncias (desses "grandes pais") no transcorrer do desenvolvimento de formação desde a fase infantil até hoje, pois, superamos coisas inauditas para compor a "elite intelectual" e contribuir para a sociedade por meio da educação.

Aos grupos familiares: Vieira, Araújo, Lôbo, Bento, Porfírio, Machado, Silva, Rocha e outros.

A todos os funcionários da Rede Municipal de Educação de Goiânia (RME), a Divisão de Educação Fundamental de Adolescentes, Jovens e Adultos, DEF-AJA e Unidade Regional de Educação (URE) Jarbas Jayme, nestes locais acumulamos riquíssimas experiências profissionais na Educação por meio dessa comunidade da EAJA.

Ao diretor da Unidade Regional de Educação Jarbas Jayme (URE), Hudson, a coordenadora pedagógica da referida URE, Juliana, aos apoios pedagógicos Angelita, Deliane, Marcelo e Raph dedicados nos estudos e na construção de intervenções nos acompanhamentos pedagógicos nas Escolas.

As grandes amigas professoras da EAJA e da turma $J$ desse curso de especialização Joacelma e Maria do Socorro tantas viagens que realizamos para Brasília e Anápolis durante o curso.

Aos nossos professores que participaram da construção do Projeto de Intervenção Local (PIL): professoras - orientadoras Ms $\underline{\text { a }}$. Juliana Alves de Araújo Bottechia e Drạ. Maria Margarida Machado obrigado pela reciprocidade e parabéns pela didática utilizada para correção do PIL; a professora (amiga e companheira) Arlene incentivando-me para a concretização dos objetivos acadêmicos e a equipe dos docentes e discentes do curso de especialização em Educação na Diversidade e Cidadania, com ênfase na EJA pela Universidade de Brasília (UnB) no âmbito da Universidade Aberta do Brasil (UAB).

À professora Cláudia, tutora presencial, pelas orientações, um exemplo para outros orientadores, sugestões, indicações de material de estudo, que foram imprescindíveis para a construção desse trabalho e aos professores e amigos do curso que muito contribuíram para nossa formação em Educação na Diversidade e Cidadania, com ênfase na EJA e EAJA. 
Vem, vamos embora Que esperar não é saber

Quem sabe faz a hora Não espera acontecer ( Composição: Geraldo Vandré) 


\section{RESUMO}

O intuito deste Projeto de Intervenção Local (PIL) é analisar a Proposta Político Pedagógica (P.P.P. 2009 versão preliminar) da EAJA, da Rede Municipal de Educação de Goiânia, questionando se realmente a P.P.P da EAJA contempla a escolarização do educando trabalhador para o Mundo do Trabalho. Neste sentido, foram feitos alguns apontamentos sobre problemas constatados no interior da escola, ora um distanciamento, ora uma aproximação entre os aportes teóricos da proposta de EAJA da SME, 2005 e 2010, e as ações implementadas. Busca-se com esse Projeto de Intervenção Local (PIL) saber se a Proposta Político Pedagógica atende às reais expectativas do adulto trabalhador que procura a EAJA e se existe relação entre o conteúdo visto e a prática no mundo do trabalho. Destaca-se algumas ações elaboradas e materializadas pela DEF-AJA (Divisão de Educação Fundamental de Adolescentes, Jovens e Adultos) e URE (Unidade Regional de Educação) para implementação da referida P.P.P. da EAJA como parâmetro nas Unidades Educacionais. Adultos

Palavras Chave: P.P.P. da EAJA - Mundo do Trabalho - Educação de Adolescentes, Jovens e 


\section{SUMÁRIO}

I. PROJETO DE INTERVENÇÃO LOCAL (PIL)

1- DADOS DE IDENTIFICAÇÃO DOS PROPONENTES..............................................

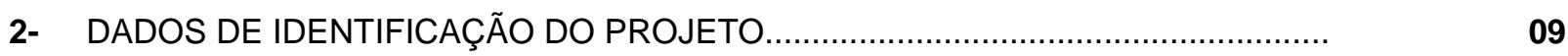

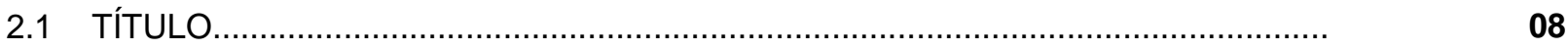

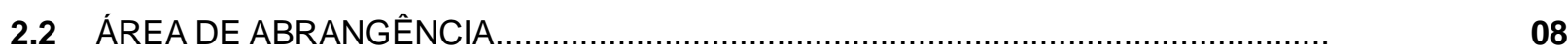

2.3 INSTÂNCIA INSTITUCIONAL DE DECISÃO....................................................

2.4 PÚBLICO AO QUAL SE DESTINA 09

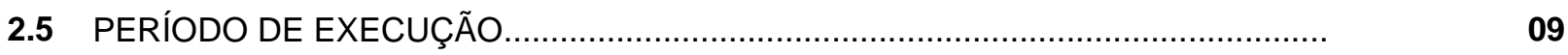

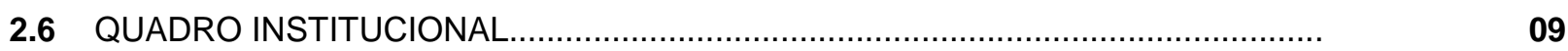

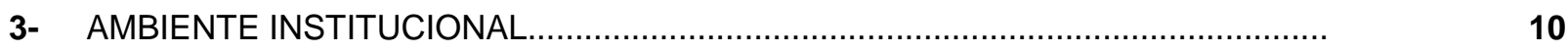

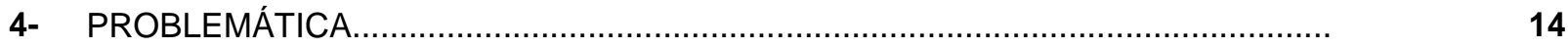

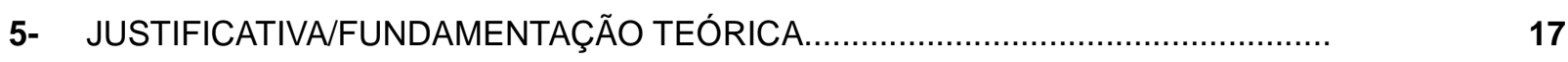

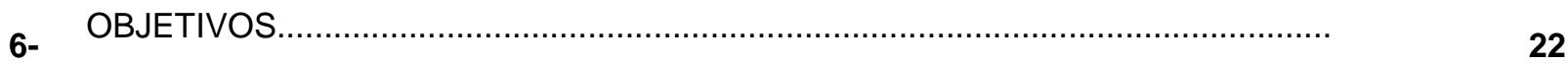

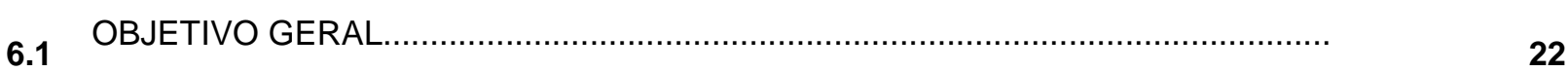

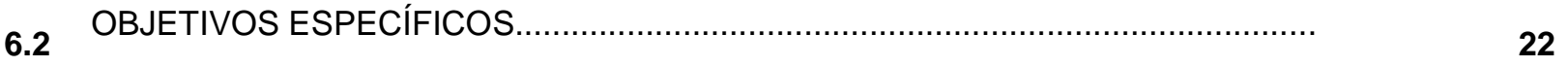

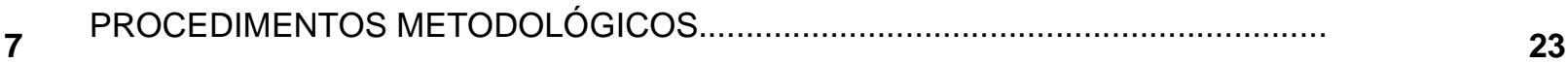

8 ATIVIDADES/RESPONSABILIDADES/CRONOGRAMA 24

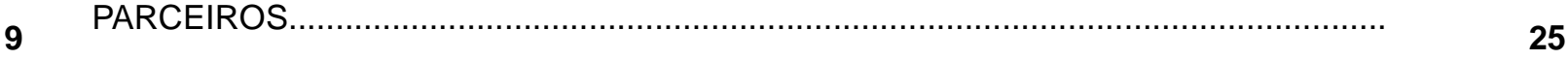

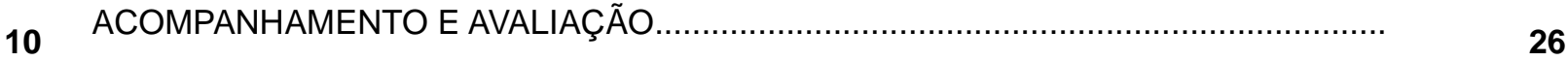

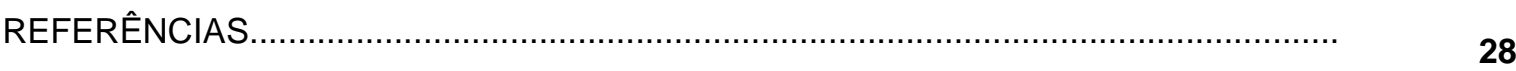

ANEXOS

II PROJETO DE INTERVENÇÃO LOCAL (PIL): RELATÓRIO DE EXPERIÊNCIA 


\section{PROJETO DE INTERVENÇÃO LOCAL (PIL)}

\section{1- DADOS DE IDENTIFICAÇÃO DOS PROPONENTES:}

AUTORES:

Margareth Matias Porfírio Machado

Rafael Vieira de Araújo,

Turma J - Pólo UAB Anápolis

ENDEREÇO POSTAL:

Rua 16-A №: 536 Aptํ: 210; Ed. Saturno; Setor Aeroporto, Goiânia-Goiás. CEP: 74.075-150

Avenida Nerópolis, Q.06 L,16 no140 Vila Clemente, Goiânia - GO, CEP: 74580-460

TELEFONES:

(62) $8115-9901$

(62) 91520312

E-MAIL:

margarethmatiasporfirio@gmail.com

rafaelv.araujo@yahoo.com.br 


\section{2- DADOS DE IDENTIFICAÇÃO DO PROJETO}

\subsection{TÍTULO:}

O Mundo do Trabalho e a Educação de Adolescentes, Jovens e Adultos na Rede Municipal de Goiânia: possibilidades e desafios.

2.2 ÁREA DE ABRANGÊNCIA: MUNICIPAL - Secretaria Municipal de Educação de Goiânia

\subsection{INSTÂNCIA INSTITUCIONAL DE DECISÃO:}

Secretaria Municipal de Educação de Goiânia: Endereço: Rua 226, esquina com 236 Setor Universitário, Goiânia - GO.

CEP 74610-130;

Unidade Regional de Educação Jarbas Jayme: Praça C com Rua C-75 - Setor Sudoeste.

\section{4 - PÚBLICO AO QUAL SE DESTINA}

Este projeto destina-se aos gestores, educadores que buscam atender às especificidades dos educandos trabalhadores da Educação de Adolescentes, Jovens e Adultos - EAJA - de Goiânia.

A versão preliminar da Proposta Político Pedagógica da EAJA (PPP, 2009) nos coloca que tanto os educadores quanto os educandos têm, como desafio, a luta pela concretização de seus direitos. A reflexão sobre a condição de trabalhador, em que educadores e educandos se encontram pode contribuir para a formação de ambos.

Assim sendo, concentraremos nosso PIL nestes dois sujeitos que compõem a EAJA: trabalhadores, que se encontram no terceiro turno, responsáveis pelo sustento da família, que vivem numa situação em que as condições de trabalho são precárias e estão em busca de romper o desafio e chegar ao término da escolarização com sucesso, utilizando na vida prática o que foi visto na escola, tendo em mente que o fazer educativo ocorre em todos os movimentos que acontecem na escola e na comunidade.

\subsection{PERÍODO DE EXECUÇÃO}

Início: Janeiro de 2010

Término: Dezembro de 2010

\subsection{QUADRO INSTITUCIONAL:}

Departamento Pedagógico, Divisão de Educação Fundamental de Adolescentes, Jovens e Adultos (DEF-AJA) e Unidade Regional de Educação JarbasłJayme. 


\section{3- AMBIENTE INSTITUCIONAL:}

O objetivo deste tópico é apresentar alguns aspectos gerais da evolução histórica da Educação de Adolescentes, Jovens e Adultos - EAJA - na Rede Municipal de Educação de Goiânia - RME. É oportuno categorizar o processo da construção histórica do sistema educacional, dando ênfase à modalidade EAJA, bem como sua importância, influência na sociedade goianiense e como foi o trato pedagógico pelas instituições educacionais, a saber: Secretaria Municipal de Goiânia - SME; Unidade Regional de Educação - URE; Unidades Educacionais - Ues; Universidade Federal de Goiás - UFG; Pontifícia Universidade Católica de Goiás - PUC Goiás e os sujeitos - pesquisadores, gestores, educadores, educandos - envolvidos no processo de elaboração e reescritos da PPP da referida modalidade.

Todavia, não se trata de um estudo detalhado, pois alguns fatos menos relevantes podem ter sido omitidos para entendimento mais fácil do contexto em que a proposta da EAJA foi desenvolvida nas unidades educacionais de Goiânia. Enfim, trata-se da contextualização do projeto com informações gerais sobre a instituição, seus atores, suas condições de existência, os problemas e os grandes desafios a serem superados. Para isso será apresentada de forma circunstanciada a instituição na qual os proponentes desse Projeto de Intervenção Local (PIL) trabalham, ou seja, na Divisão de Educação Fundamental de Adolescentes, Jovens e Adultos -DEF-AJA- e Unidade Regional de Educação Jarbas Jayme.

A Divisão de Educação Fundamental de Adolescentes, Jovens e Adultos, DEFAJA, nasceu com a preocupação de implementar políticas públicas para tal modalidade. De acordo com a versão preliminar da Proposta Política Pedagógica da Educação de Adolescentes, Jovens e Adultos (2009) em 2001, instituiu-se, como parte integrante do Departamento Pedagógico, a Divisão de Ensino Fundamental Noturno, posteriormente redefinida como Divisão de Educação Fundamental de Adolescentes, Jovens e Adultos DEF-AJA, numa caracterização dos sujeitos do processo educativo e das defesas empreendidas em prol da inclusão da EJA na categoria de modalidade do Ensino Fundamental.

Conforme a Proposta Político Pedagógica da EAJA versão preliminar (2009) a estrutura estabelecida na Rede Municipal de Educação/RME, em que 368 Instituições Educacionais estão subdivididas em cinco Unidades Regionais de Educação/UREs, que exercem um papel de coordenação e acompanhamento pedagógico às escolas. A função do apoio pedagógico é estudar, compreender e construir possibilidades de intervenções na 
Escola.

A Secretaria Municipal de Educação de Goiânia foi efetivada como instituição mantenedora das escolas municipais em 1961. Até então, desde a fundação de Goiânia, em 1935, as escolas do município eram mantidas pelo Poder Estadual.

Para garantir o desenvolvimento de sua estrutura, a SME estabelece diretrizes e políticas, além de promover ações organizacionais e pedagógicas no âmbito da administração da educação pública municipal. Na constituição desse aparato a SME conta, mais recentemente, com o Conselho Municipal de Educação (CME), que se organizou a partir de 1998.

Conforme dados do Departamento de Administração Educacional da SME (DAE), a Rede Municipal de Educação (RME) é formada por 368 instituições educacionais, composta por 254 escolas (92 destas possui a modalidade EAJA), 114 Centros Municipais de Educação Infantil (CMEIS).

Em relação à política de Educação de Jovens e Adultos, em 1992 foi criado um grupo de estudos e elaborado o Projeto Alfabetização e Cidadania, numa parceria entre Universidade Federal de Goiás - UFG e SME, como forma de viabilizar uma educação para adolescentes em situação de risco - Projeto Alfabetização de Jovens e Adultos - AJA.

Com a implantação do Projeto AJA, a rede passou a conviver com duas formas de atendimento, sendo uma seriada e outra modulada. Isso desencadeou, em 1994, um processo rico de reflexões sobre as possíveis mudanças que poderiam se efetivar na EAJA.

Em 1998, foi criado o Conselho Municipal de Educação - CME, que passou a regulamentar as diretrizes que norteiam o funcionamento desse Sistema Municipal de Ensino, incluindo a EAJA.

Em 1999, tendo em vista o processo empreendido no ano anterior, foi implantada uma proposta para o Ensino Fundamental (1 $1^{\underline{a}}$ a $4^{\underline{a}}$ série), que apresentava uma organização alternativa para o cumprimento da carga horária prevista na Lei de Diretrizes e Bases da Educação Nacional n. 9,394/96. Ainda em 1999, as discussões sobre a Base Paritária foram retomadas e, em 2000, foi possível implantá-la. Foi regulamentada por meio da ResoluçãoCME no 024 de 11 de dezembro de 2000.

Em plenárias realizadas com professores do Projeto AJA e da EAJA de $1^{\text {aa }}$ à $4^{a}$ série, a SME optou por reduzir as diferenças estabelecidas neste atendimento, definindo, na $1^{\underline{a}}$ à $4^{\underline{a}}$ série, uma carga horária de $600 \mathrm{~h}$ presenciais e $200 \mathrm{~h}$ de atividades complementares, na tentativa de unificação aprovada pelo CME, na Resolução no 037 de 20 de março de 2002 .. Essa opção viabilizou o financiamento para EAJA da RME, enquanto Ensino Fundamental.

Em 2002 é constituído o Fórum Goiano de EJA. A SME de Goiânia foi uma das articuladoras do processo desde 1999. Esse movimento tem contribuído para o 
entendimento das especificidades da modalidade de EJA e para o seu fortalecimento, enquanto direito, na RME, uma vez que a SME viabiliza a participação de gestores, professores e educandos nos encontros promovidos por este movimento.

Com fundamentos nas discussões, estudos e realizações empreendidas desde 1992, foi iniciada em 2001, com a assessoria da faculdade de educação/UFG, uma pesquisa denominada "A construção de uma proposta democrático-popular de educação para adolescentes, jovens e adultos da Rede Municipal de Educação de Goiânia, pelos sujeitos do processo educativo". Dentre as 89 escolas, 40 aderiram ao processo de pesquisa intervencionista, cujo objetivo era a reorientação curricular da EAJA.

A partir de 2001, todo Ensino Noturno passou a denominar-se "Educação de Adolescentes, Jovens e Adultos", uma vez, que os sujeitos atendidos neste turno, possuíam características e trajetórias de vida de alunos desta modalidade.

A SME preocupada em atender a uma demanda significativa de pessoas não alfabetizadas e incluí-las socialmente, criou, a partir do segundo semestre de 2001, 0 Projeto AJA - Expansão, com o objetivo de mobilizar e sensibilizar a população acima de 15 anos para o processo inicial de leitura e escrita. Esse Projeto, desenvolvido em parceria com movimentos sociais, empresas, igrejas e associações entre outros, realiza suas atividades em espaços alternativos com a participação de educadores populares em regime de voluntariado. Em 2003, a SME firma parceria com o Governo Federal, por meio do Programa Brasil Alfabetizado. O projeto passa a ser denominado "Programa AJA-Expansão/Brasil Alfabetizado."

Em 2008, a DEF-AJA retomou a avaliação da Proposta Política-Pedagógica e pediu sua prorrogação, junto ao CME. Partiu-se então para a avaliação e reescrita coletiva da Proposta Política Pedagógica da Educação de adolescentes, Jovens e Adultos, ouvindo educando e educadores por meio de pesquisas in loco, reuniões, assembléias e plenárias, contando com assessoria da UFG, através das professoras Maria Margarida Machado e Maria Emília Castro Rodrigues. Esta Proposta foi enviada ao Conselho Municipal de Educação de Goiânia no dia 25 de novembro de 2009.

O atendimento da população de adolescentes, jovens e adultos pela Rede Municipal de Educação de Goiânia é organizado, atualmente, na seguinte estrutura segundo dados da SME-2010 (ver organograma em anexo):

- Programa AJA-Expansão Educação Popular/Alfabetização: Atualmente com 43 turmas sendo que os locais de atuação são as escolas da Rede Municipal de Educação, Empresas, Órgãos Públicos, Associações de Bairros e Idosos, Igrejas e outros. A carga horária é de $2 \mathrm{~h}$ e $30 \mathrm{~min}$ de aula diariamente ( $2^{\mathrm{a}}$ à $5^{\mathrm{a}}$ feira), a avaliação é processual e contínua. A formação continuada acontece, semanalmente, com a Assessoria da UFG e 
efetivada pela SME e Coordenadores Populares. Tem como objetivo o aprofundamento dos princípios, acompanhamento e avaliação da prática pedagógica.

- Educação Fundamental de Adolescentes, Jovens e Adultos 1a A 8 ${ }^{a}$ Série - EAJA: O primeiro segmento da EAJA está inserido na organização de EJA, não sendo necessário o cumprimento de no mínimo 800h de atividades pelo educando. Sendo assim, a estrutura do primeiro segmento corresponde a 200 dias letivos, $600 \mathrm{~h}$ anuais para o educando totalizando carga horária mínima de 2400h (4 etapas, uma em cada ano). A avaliação é processual, contínua, com registro descritivo trimestral e o avanço a qualquer momento do ano letivo. Enquanto que o segundo segmento da EAJA está inserido na organização do Ensino Fundamental regular tendo então a necessidade de cumprimento de no mínimo 200 dias letivos totalizando um mínimo de $800 \mathrm{~h}$ anuais. 


\title{
4- PROBLEMÁTICA
}

Em 2010, o Centro de Formação dos Profissionais da Educação "Paulo Freire" CEFPE, a DEF-AJA, as Unidades Regionais de Educação (URES) e as Unidades Educacionais continuam os estudos e discussões com o intuito da implementação da Proposta Política Pedagógica da EAJA sendo que a mesma esta em fase de análise e aprovação do Conselho Municipal de Educação de Goiânia.

A Proposta Político-Pedagógica da EAJA na versão preliminar caracteriza-se pela intrínseca relação entre eixos, princípios, objetivos, organização curricular, metodologia e avaliação, numa perspectiva dialética.

\begin{abstract}
A Educação de Adolescentes, Jovens e Adultos - EAJA está intrinsecamente voltada para inclusão de pessoas em contextos: social, econômico, cultural e geracional diferenciados. Nesta perspectiva, ela se relaciona à educação popular1, visando a emancipação dos sujeitos. Oferece flexibilidade no horário de início e término da jornada diária, respeitando as condições do educando, sem comprometer a qualidade do ensino ou ferir os dispositivos legais. (PPP, 2009, p.5).
\end{abstract}

Assim, a proposta da EAJA é garantir acesso aos saberes e conhecimentos com condições específicas e indispensáveis para a vida cidadã e para o mundo do trabalho. Tem como ponto de partida a realidade dos educandos, buscando desenvolver seu senso crítico, sendo papel do professor, realizar pesquisa na comunidade, levantando as problemáticas/necessidades e a explicação que os educandos têm para estas.

$\mathrm{Na}$ pesquisa intitulada "O trabalhador-aluno da Eaja: desafios no processo ensinoaprendizagem" (2008), da autora Cláudia Borges Costa, e na monografia de especialização com o tema "Perfil do Jovem Trabalhador da Educação de Adolescentes, Jovens e Adultos" (2009) da autora Maria Jacqueline Dias Alves, ambas investigaram a realidade de adolescentes, jovens e adultos trabalhadores da Rede Municipal de Goiânia. Os referentes estudos apontaram os seguintes problemas: apenas delimitar, no referencial teórico da proposta, o sentido do trabalho, torna-se uma certa superficialidade e não contribui para que,de fato, a categoria trabalho faça parte da prática pedagógica cotidiana; em seus princípios não se aborda a categoria trabalho como se afirma no referencial teórico, que deve ser pauta no processo educacional da Eaja. Essas problemáticas supracitadas ainda constam na realidade educacional dos educandos trabalhadores e na Proposta Pedagógica da EAJA na versão preliminar de 2009, ou seja, não explicita uma formação que contribua para enfrentar a dicotomia entre mundo do trabalho/ Eaja. 
Embora a proposta deixe clara a concepção de trabalho, não incorpora esta categoria nos princípios e nem explicita uma formação que contribua para enfrentar a dicotomia histórica trabalho/educação. Nesta perspectiva, apenas delimitar, no referencial teórico da proposta, o sentido do trabalho, torna-se uma certa superficialidade e não contribui para que, de fato, a categoria trabalho faça parte da prática pedagógica cotidiana. (COSTA, 2008)

Nos acompanhamentos pedagógicos dos apoios da URE e na análise do Projeto Político Pedagógico das escolas no ano letivo de 2010, alguns problemas também foram identificados no interior da escola. Conforme Gomes, Costa e Santos (2005) ora um distanciamento, ora uma aproximação entre os aportes teóricos da proposta de EAJA da SME e as ações implementadas. Observam a existência de uma escola pautada bem mais em ações pedagógicas direcionadas para o aluno, diferentemente, de ações pedagógicas construídas com o educando e capazes, portanto, de levá-lo a alargar a sua tomada de consciência frente ao mundo em que está inserido para que possa, unindo-se a outros, transformá-lo.

As dificuldades das escolas que oferece o ensino da EAJA apóiam às vezes em práticas e ações pedagógicas descontextualizadas com a realidade do educando possibilitando causas de fracasso escolar, a saber: aumento na evasão escolar; desinteresse dos educandos pela aprendizagem; inadequação das práticas ao perfil dos estudantes (infantilização); currículos fragmentados e cientificistas, excessivamente tecnicista e disciplinarista; critérios desarticulados entre si para seleção e organização dos "conteúdos significativos"; dificuldade de diálogo entre as experiências vividas, os saberes anteriores dos educandos; migração de alguns alunos do Ciclo de Formação e Desenvolvimento Humano ${ }^{1}$ para a EAJA e conteúdos escolares com currículo impróprio, sobretudo, para o aluno trabalhador, da EAJA.

Apresentado esse contexto da EAJA no município de Goiânia verifica-se a importância da materialização da proposta curricular de forma qualitativa para a construção do currículo que viabiliza compreender o trato pedagógico que as escolas oferecem para essa modalidade.

Continuo defendendo que estamos em um momento muito delicado para a EJA: ou diluí-la nas modalidades escolarizadas de ensino fundamental e médio vistas como a forma ideal, ou configurá-la como um campo específico do direito à educação e à formação de coletivos marcados por constantes sociais. (ARROYO, 2006, p.34).

1 A educação fundamental, em Goiânia, estruturada a partir dos Ciclos de Formação e Desenvolvimento Humano propõe a reorganização dos tempos, dos espaços, dos saberes, das experiências de socialização. Os educandos passaram a ser agrupados por idade, baseando-se na lógica das fases do desenvolvimento: a infância, dos 6 aos 8 anos; o ciclo da pré-adolescência, dos 9 aos 11 e o da adolescência, dos 12 aos 14 . 
Por isso o objeto de estudo foi delimitado na análise da Proposta Político Pedagógica (P.P.P) da EAJA da Rede Municipal de Educação de Goiânia, observando a realidade vivenciada nas escolas por educandos trabalhadores e educadores da EAJA, no sentido de levantar contribuições para essa modalidade da Educação, pois expressa uma forma de conceber a sociedade, o ser humano e a educação. Desta forma, apresenta-se como problemática as seguintes questões: A Proposta Pedagógica da EAJA contempla o educando-trabalhador? As escolas da EAJA utiliza como parâmetro o projeto da SME para elaborar o seu Projeto Político- Pedagógico (PPP)? 


\section{5- JUSTIFICATIVA/FUNDAMENTAÇÃO TEÓRICA}

Este projeto de intervenção local tem como intuito analisar a Proposta Político Pedagógica (P.P.P) da EAJA da Rede Municipal de Educação de Goiânia, observando a realidade vivenciada nas escolas por educandos trabalhadores e educadores da EAJA, no sentido de levantar contribuições para essa modalidade da Educação. Refletir por meio dessa totalidade social é constatar os erros e acertos, pontos de avanço e defeitos, possibilidades e limitações.

O principio é partir sempre de uma discussão do "macro" para o "micro", ou seja, apresentar o contexto do sistema educacional no país até chegar às políticas públicas para a EAJA, na Rede Municipal de Ensino (RME) de Goiânia. A discussão nessa parte refere-se à educação de modo geral, destacando seu caráter político e social.

Ao passar por várias dificuldades desde as políticas sociais, as questões de infraestrutura das instituições até ao processo de ensino-aprendizagem, percebe-se que há a prática na educação permanece a mesma. Os cenários contemporâneos presenciam problemas sociais como: discrepância na distribuição de renda, desigualdades sociais, altos índice de analfabetismo, fome, péssimo funcionamento do sistema único de saúde, violência, desajuste dos princípios familiares, corrupção, desvio de verbas, etc. Esses fatores contribuem para alienação e retardamento na vida escolar da maioria dos jovens brasileiros que desistem de estudar e passam a trabalhar para a subsistência da família. Todos esses aspectos corroboram para a barbárie na educação, mas como desbarbarizar?

Superar a dificuldade de reconhecer que, além de alunos ou jovens
evadidos ou excluídos da escola, antes do que portadores de trajetórias
escolares truncadas, eles e elas carregam trajetórias perversas de exclusão
social, vivenciam trajetórias de negação dos direitos mais básicos à vida, ao
afeto, à alimentação, à moradia, ao trabalho e à sobrevivência. (ARROYO,
2006, p.24).

Nesse contexto social as crianças e os jovens brasileiros são prejudicados em seu desenvolvimento escolar atrasando sua formação na Educação Básica, que posteriormente o mundo de trabalho ou a sociedade exige um grau de estudo mais elevado para qualificação profissional.

Isso significa que a EAJA, como um campo político de formação e de investigação, está irremediavelmente comprometida com a educação das camadas populares e com a superação das diferentes formas de exclusão e discriminação existentes em nossa sociedade, as quais se fazem presentes tanto nos processos educativos escolares quanto nos não escolares. (SOARES, GIOVANETTI, GOMES, 2006 p.8).

As pessoas que escolhem cursar a EAJA buscam novas oportunidades para a sua 
vida, através de uma formação escolar que foi impossibilitada em sua trajetória escolar. A realidade da escola da EAJA é de alunos trabalhadores, que buscam além do saber, a integração social e o resgate da auto-estima, e isto se torna um desafio para os educadores e para a escola em geral, que precisam motivar seus alunos ao longo dos seus estudos.

Diante dessa especificidade, vai tornando-se cada vez mais claro que escolarizar adolescentes, jovens e adultos trabalhadores, independentemente da etapa em que esteja atuando o professor, não é reproduzir ou adaptar o ensino de crianças para adultos, mas sim, articular com o mundo do trabalho.

Um dos principais representantes da Educação de Jovens e Adultos foi o educador Paulo Freire, que na década de 1960 foi fortalecido pela indignação política e a importância da alfabetização de jovens e adultos para o processo educacional. Esse autor argumentava que todo ato educativo é um ato político, e defendia uma educação popular, baseada na pedagogia libertadora, que buscasse a autonomia dos alunos oprimidos em virtude das conseqüências da realidade social. Ou seja, ele defendia que o ponto de partida do processo de ensino-aprendizagem é a prática social dos alunos, pois a formação do povo deveria ser pensada como educação, não apenas como ensino. Conforme Arroyo "o Movimento de Educação Popular e Paulo Freire não se limitaram a repensar métodos de educação-alfabetização de jovens e adultos, mas recolocaram as bases e teorias da educação e da aprendizagem" (2006, p.36).

A EAJA é direito do educando trabalhador. Trata-se de uma alternativa para a escolarização daqueles que foram alijados da escola por inúmeros fatores. $O$ público que compõe o atendimento da EAJA são jovens que pertencem às classes populares e necessitam ingressar no mundo do trabalho, mesmo ainda não estando preparados.

Existe uma diferenciação entre mundo do trabalho e mercado de trabalho como sugere Carneiro (2010) quando explica que o primeiro constitui o campo de construção e realização da cidadania humana ao passo que "o segundo é lugar da empregabilidade, dos postos fixos de ocupação e, portanto, da profissionalidade" distingue mundo de trabalho de mercado de trabalho. distingue mundo de trabalho de mercado de trabalho" (CARNEIRO, 2010, p.40). Embora antagônicos, estes conceitos se completam em uma visão unificadora de desenvolvimento e formação.

Nesse sentido, a articulação da EAJA com o mundo do trabalho torna-se a possibilidade de concretização da cidadania. Segundo Libâneo (2009) o mundo do trabalho se dá por meio da "incorporação de conhecimentos, habilidades técnicas, de novas formas de solidariedade social, de vinculação entre trabalho pedagógico e lutas sociais pela democratização do Estado" (LIBÂNEO, 2009, p.118).

As principais ideias extraídas são que o trabalho - objeto do capitalismo - é necessário 
ao homem, porém essa necessidade está condicionada a fatores desumanos, resultantes da alienação, estranhamento e ameaça ao homem lúdico para o homem opressor como esclarece Antunes (2004):

(...) o trabalho é uma atividade central na história humana, em seu processo de sociabilidade e mesmo para a sua emancipação. Por outro lado, com o advento do capitalismo, houve uma transformação essencial, que alterou e tornou complexo o trabalho humano. A desconsideração dessa dupla dimensão, presente no mundo do trabalho, permitiu que muitos autores, equivocadamente, defendessem o fim da atividade laborativa, o fim do trabalho. (ANTUNES, 2004, p.10)

Para a real transformação, os oprimidos devem por meio do trabalho materializar a práxis, ou seja, transformar o mundo pelo diálogo tendo como objetivos a libertação, a emancipação, a conscientização e a educação dos homens entre si.

Dessa forma o conceito de trabalho compreende como atividade humana criativa que não se reduz ao mercado, nem ao caráter produtivo no sentido econômico strictu sensu, ou seja, é uma condição humana que possibilita o trabalhador ser criativo e transformador.

Para isso o mundo do trabalho com a economia solidária pode ser pensado como estratégia de superação do "desemprego estrutural do capitalismo" e elementos essenciais para ressignificar o currículo da EAJA no município de Goiânia. Conforme Arruda (2005, p.37) "a Economia Solidária promove a educação não como fim em si, mas como via de empoderamento dos educandos para tornarem-se gestores competentes dos seus empreendimentos cooperativos e sujeitos do seu próprio desenvolvimento pessoal, comunitário e social".

Nessa configuração o professor pode ser um dos responsáveis na mediação do conhecimento bem como na contribuição para o processo de emancipação do educando em relação à realidade capitalista e do mundo opressor.

Portanto, a concepção freireana de educação relacionada ao mundo do trabalho é pautada no respeito aos sujeitos como produtores do conhecimento na perspectiva de recomeço por meio da aprendizagem. Nesta linha, segundo Costa "existe dualidade entre a educação básica e mundo do trabalho e a dificuldade de o aluno trabalhador manter-se na escola e terminar com sucesso sua formação escolar. Percebe-se, também, a falta de articulação dos conteúdos trabalhados com a realidade dos sujeitos da EJA" (COSTA, 2008, p.14).

Partindo da concepção de trabalho apresentada na PPP da EAJA, e considerando a diversidade da população como os grupos étnico-raciais, índios, negros e os que necessitam de atendimento especial, busca-se com esse Projeto de Intervenção Local (PIL) saber se a Proposta Político Pedagógica atende às reais expectativas do educando 
trabalhador que procura a EAJA e se existe relação entre o conteúdo visto e a prática no mundo do trabalho.

A EJA é também espaço de tensionamento e aprendizagem em diferentes
ambientes de vivências que contribuem para a formação de jovens e adultos
como sujeitos da história. Nesses espaços, a EJA volta-se para um conjunto
amplo e heterogêneo de jovens e adultos oriundos de diferentes frações da
classe trabalhadora. Por isso, é compreendido na diversidade e
multiplicidade de situações relativas às questões étnico-racial, de gênero,
geracionais; de aspectos culturais e regionais e geográficos; de orientação
sexual; de privação da liberdade; e de condições mentais, físicas e
psíquicas - entendida, portanto, nas diferentes formas de produção da
existência, sob os aspectos econômico e cultural. Toda essa diversidade
institui distintas formas de ser brasileiro, que precisam incidir no
planejamento e na execução de diferentes propostas e encaminhamentos
na EJA. (BRASIL, 2008, p.13).

Desta forma, espera-se fazer uma análise da realidade vivenciada nas escolas por educandos trabalhadores e educadores da EAJA, na perspectiva de levantar contribuições para essa modalidade da Educação no intuito de contribuir as pesquisas sobre a EJA e o mundo do trabalho.

Justifica-se então o presente projeto por se tratar de um tema atual e relevante para a área da Educação, da EAJA, ou seja, para a necessidade de organizar o currículo integrado que parta da realidade do aluno da EAJA, valorizando os saberes dos educandos produzidos no cotidiano e indo além, abrindo espaço na escola para a luta social e a resistência à dominação. Assim, este estudo pretende observar na Proposta Pedagógica da EAJA na RME de Goiânia a questão do educando-trabalhador. É notório que precisamos trabalhar saberes específicos para o aluno trabalhador na escola bem como organizar e seqüenciar estes saberes, no sentido de viabilizar para que as aprendizagens significativas efetivamente ocorram.

A partir deste contexto, é oportuno expor que a proposta do PROEJA contribuirá bastante para a P.P.P da EAJA quanto ao currículo integrado e ao educando trabalhador. $\mathrm{Na}$ EAJA temos diferentes sujeitos com experiências no Mundo do Trabalho diversificadas. É o caso dos adolescentes que precisa inserir nesse Mundo do Trabalho. Outros jovens, adultos precisam de um saber mais elaborado para ampliar sua visão no mercado de trabalho informal. Idosos em relação a vida e o trabalho. Reflexão, ação e reflexão. O PROEJA tem como perspectiva a proposta de integração da educação profissional à educação básica buscando a superação da dualidade trabalho manual e intelectual, assumindo o trabalho na sua perspectiva criadora e não alienante. 
Nesse contexto, a integração da formação inicial e continuada de trabalhadores com o ensino fundamental na modalidade EJA é uma opção que tem possibilidade real de conferir maior significado a essa formação, pois tem o poder de incidir diretamente na melhoria da qualificação profissional dos sujeitos aos quais se destina. Não se trata, de maneira alguma, de subsumir o conteúdo propedêutico do ensino fundamental a uma preparação para o mundo do trabalho, mas sim de garantir a totalidade do primeiro integrando-o à segunda. (BRASIL, 2007, p.19)

Dessa forma, o presente projeto pode se fundamentar na Pedagogia Libertadora de Paulo Freire (1981); os estudos de Vygotsky (1987) sobre o desenvolvimento humano e as pesquisas contemporâneas de Arroyo (2006) e Antunes (2004), dentre outros

Os cuidados éticos da pesquisa constituirão com um termo de consentimento livre e esclarecido (anexo) para a instituição escolar pesquisada ressaltando que sua identidade é de caráter sigiloso e jamais será revelada, bem como os participantes da pesquisa tem o direito de retirar o seu consentimento a qualquer tempo. 


\section{6- OBJETIVOS}

\subsection{OBJETIVO GERAL}

Analisar a Proposta Político Pedagógica (P.P.P.) da EAJA, da Rede Municipal de Educação de Goiânia, observando se a proposta curricular da mesma contempla uma formação do educando trabalhador para o mundo do trabalho.

\subsection{OBJETIVOS ESPECÍFICOS}

- Estudar a proposta curricular da Educação de Adolescentes, Jovens e Adultos da Rede Municipal de Ensino de Goiânia (RME);

- Investigar o contexto socio-histórico da realidade escolar de adultos trabalhadores;

- Compreender a construção do currículo da EAJA e do Projeto-Político Pedagógico da Escola pesquisada em relação aos conteúdos na organização do processo de ensino-aprendizagem nessa modalidade de ensino;

- Verificar se a escola da EAJA pesquisada utiliza como parâmetro o projeto da SME para elaborar o seu Projeto Político- Pedagógico (PPP);

- Observar o conceito de trabalho apresentado na P.P.P. da EAJA;

- Analisar se realmente a P.P.P da EAJA contempla o educando trabalhador. 


\section{7- PROCEDIMENTOS METODOLÓGICOS}

O Projeto de Intervenção Local (PIL) é de cunho qualitativo, baseado no método de abordagem Dialética, ou seja, que penetra o mundo dos fenômenos através de sua ação recíproca, da contradição inerente ao fenômeno e da mudança dialética que ocorre na natureza e na sociedade. Tem como procedimentos metodológicos, a pesquisa bibliográfica, documental e empírica.

\subsection{CONTEXTO DE PESQUISA}

Será contexto da presente pesquisa uma escola pública em Goiânia, que oferece a EAJA, cujo critério de seleção será buscar uma escola que atenda essa modalidade de ensino, no período noturno, para que seja possível observar um espaço composto por educandos trabalhadores.

\subsection{SUJEITOS}

Serão sujeitos da pesquisa os profissionais da instituição selecionada, abrangendo: gestores, coordenação, 02 docentes, educandos e 02 funcionários administrativos. Acreditase que tal quantidade de profissionais poderá atender os objetivos propostos no estudo. Também serão participantes uma turma de alunos da EAJA, cujo critério de seleção será buscar pessoas que estudam e trabalham, e apresentem uma boa freqüência às aula 


\section{ATIVIDADES/RESPONSABILIDADES/CRONOGRAMA}

Verifique em anexo as ações para os acompanhamentos e para o trabalho da equipe da Eaja da Unidade Regional de Educação Jarbas Jayme.

\begin{tabular}{|c|c|c|}
\hline Atividades & PERÍODO & Responsabilidades \\
\hline Relatórios de observação & $\begin{array}{c}\text { Janeiro a } \\
\text { dezembro/2010 }\end{array}$ & Proponentes do PIL \\
\hline Revisão bibliográfica & $\begin{array}{c}\text { Janeiro a } \\
\text { junho/2010 }\end{array}$ & Proponentes do PIL \\
\hline $\begin{array}{l}\text { Redação do Projeto de } \\
\text { Intervenção Local }\end{array}$ & $\begin{array}{l}\text { Setembro/2009 a } \\
\text { Junho/2010 }\end{array}$ & Proponentes do PIL \\
\hline $\begin{array}{l}\text { Acompanhar a elaboração do } \\
\text { Plano de Ação de estudo e } \\
\text { implementação do PPP da } \\
\text { EAJA; }\end{array}$ & $\begin{array}{c}\text { Janeiro a } \\
\text { Dezembro/2010 }\end{array}$ & $\begin{array}{c}\text { Apoios pedagógicos da URE } \\
\text { Jarbas Jayme }\end{array}$ \\
\hline $\begin{array}{l}\text { Acompanhar as ações de } \\
\text { implementação da P.P.P da } \\
\text { EAJA }\end{array}$ & $\begin{array}{c}\text { Fevereiro a } \\
\text { Dezembro/2010 }\end{array}$ & $\begin{array}{c}\text { Apoios pedagógicos da URE } \\
\text { Jarbas Jayme }\end{array}$ \\
\hline $\begin{array}{l}\text { Realizar estudo/encontro } \\
\text { semanal da equipe da EAJA } \\
\text { com a coordenação da URE } \\
\text { JJ às quintas-feiras; }\end{array}$ & $\begin{array}{c}\text { Janeiro a } \\
\text { Dezembro/2010 }\end{array}$ & $\begin{array}{c}\text { Coordenadora e apoios } \\
\text { pedagógicos da URE Jarbas } \\
\text { Jayme }\end{array}$ \\
\hline $\begin{array}{l}\text { Redação do Relato de } \\
\text { experiências }\end{array}$ & $\begin{array}{c}\text { Janeiro a } \\
\text { Dezembro/2010 }\end{array}$ & Proponentes do PIL \\
\hline Realização das entrevistas & Agosto/2010 & Proponentes do PIL \\
\hline Aplicação dos questionários & $\begin{array}{c}\text { Agosto a } \\
\text { Outubro/2010 }\end{array}$ & Proponentes do PIL \\
\hline $\begin{array}{l}\text { Análise e discussão dos } \\
\text { resultados }\end{array}$ & $\begin{array}{c}\text { Maio a } \\
\text { Dezembro/2010 }\end{array}$ & Proponentes do PIL \\
\hline Introdução & $\begin{array}{c}\text { Maio a } \\
\text { Dezembro/2010 }\end{array}$ & Proponentes do PIL \\
\hline Conclusão & Dezembro/2010 & Proponentes do PIL \\
\hline Revisão do Conteúdo & Junho/2010 & Proponentes do PIL \\
\hline Revisão Metodológica & Junho/2010 & Proponentes do PIL \\
\hline Revisão Ortográfica & Junho/2010 & Proponentes do PIL \\
\hline $\begin{array}{l}\text { Preparação para } \\
\text { Apresentação ao Público }\end{array}$ & Junho/2010 & Proponentes do PIL \\
\hline Apresentação ao público & Junho/2010 & Proponentes do PIL \\
\hline $\begin{array}{l}\text { Orientar e subsidiar a } \\
\text { elaboração do Projeto } \\
\text { Político-Pedagógico da } \\
\text { escola }\end{array}$ & $\begin{array}{l}\text { Janeiro a } \\
\text { junho/2010 }\end{array}$ & Proponentes do PIL \\
\hline $\begin{array}{l}\text { Viabilizar a adesão ao } \\
\text { PROEJA-FIC }\end{array}$ & $\begin{array}{c}\text { Janeiro a } \\
\text { dezembro/2010 }\end{array}$ & SME; DEF-AJA; UFG \\
\hline Divulgar a Proposta EAJA no & Janeiro a & SME; DEF-AJA; UFG \\
\hline
\end{tabular}




\begin{tabular}{|c|c|c|}
\hline $\begin{array}{l}\text { sitio eletrônico do Fórum de } \\
\text { EJA-Brasil; }\end{array}$ & dezembro/2010 & \\
\hline $\begin{array}{l}\text { Reunião mensal com } \\
\text { assessoria FE/UFG; }\end{array}$ & $\begin{array}{c}\text { Janeiro a } \\
\text { dezembro/2010 }\end{array}$ & DEF-AJA;UFG \\
\hline $\begin{array}{l}\text { Socialização da Proposta em } \\
\text { Universidades e outros } \\
\text { espaços; }\end{array}$ & $\begin{array}{c}\text { Janeiro a } \\
\text { dezembro/2010 }\end{array}$ & DEF-AJA;UFG \\
\hline $\begin{array}{l}\text { Encontro mensal com apoios } \\
\text { pedagógicos que atendem a } \\
\text { EAJA; }\end{array}$ & $\begin{array}{c}\text { Janeiro a } \\
\text { dezembro/2010 }\end{array}$ & DEF-AJA \\
\hline Realização de Colóquio & $\begin{array}{c}\text { Junho a } \\
\text { dezembro/2010 }\end{array}$ & DEF-AJA \\
\hline $\begin{array}{l}\text { Realização de Seminário } \\
\text { EAJA }\end{array}$ & $\begin{array}{c}\text { Junho a } \\
\text { dezembro/2010 }\end{array}$ & $\begin{array}{c}\text { Prefeitura de Goiânia; SME e } \\
\text { DEF-AJA }\end{array}$ \\
\hline
\end{tabular}

\section{Parceiros:}

Prefeitura de Goiânia

Ministério da Educação, DEJA, Secad

Secretaria Municipal de Educação;

Centro de Formação dos Profissionais da Educação "Paulo Freire" - CEFPE;

DEF-AJA;

Unidades Regionais de Educação (URES);

Unidades Educacionais;

Universidade Federal de Goiás - UFG;

Pontifícia Universidade Católica de Goiás - PUC Goiás.

Cooperativas (Economia Solidária).

Fórum EJA 


\section{Acompanhamento e avaliação:}

Para avaliar o desenvolvimento das atividades propostas no PIL serão utilizados relatórios escritos de acompanhamento das ações, visando ampliar as possibilidades de construção de informações. Assim, serão utilizados questionários visando analisar a situação sócio-demográfica dos educandos por meio de entrevistas semi-estruturadas com os profissionais da instituição, visando conhecer o contexto e as características do processo educativo.

Outro instrumento de acompanhamento e avaliação do PIL parte da elaboração das perguntas para os participantes do projeto de intervenção como forma de analisar visões, opiniões e conceitos diferenciados dos professores, gestores e educandos envolvidos com a EAJA. Também será realizada uma análise documental do currículo, com o objetivo de identificar e analisar as propostas da EAJA do ano de 2005 e da versão preliminar (2009). Estudar e comparar quais as contribuições dos documentos relacionados ao PROEJA e ao PROJOVEM para o Mundo do Trabalho.

Durante o primeiro semestre de 2010 o acompanhamento dos PPPs das escolas será realizado no sentido de verificar se realmente ocorreu o estudo da implementação da proposta da RME. Os apoios da URE Jarbas Jayme elaboraram um instrumento (ver anexo) para análise do Projeto-Político Pedagógico/2010 das escolas da RME Goiânia.

No segundo semestre será utilizado os indicadores da qualidade na educação de adolescentes jovens e adultos e efetivação da proposta político-pedagógica da RME. Este instrumento (ver anexo) foi construído pelos apoios pedagógicos da URE Jarbas Jayme, que acompanham a EAJA, com base no documento do MEC "Indicadores da Qualidade na Educação" (AÇÃO EDUCATIVA, São Paulo, 2007. 3a Edição ampliada) e na Proposta Político-pedagógica da EAJA da Rede Municipal de Educação de Goiânia (Versão Preliminar, 2009). Os objetivos desse instrumento são: ajudar a comunidade escolar a avaliar e melhorar a qualidade da educação de sua escola e auxiliar na garantia da efetivação da proposta da EAJA da RME.

Para que toda a comunidade escolar reflita no sentido de melhorar a qualidade da educação de sua escola, foram definidas seis dimensões as quais representam os elementos de qualidade considerados para Educação de Adolescentes Jovens e Adultos, sendo elas: Ambiente Educativo, Prática Pedagógica e Avaliação, Ensino e Aprendizagem da Leitura e da Escrita, Gestão Escolar Democrática, Acesso e Permanência na Escola, Implementação da Proposta Político-Pedagógica da EAJA. Cada dimensão é constituída por um grupo de indicadores que representam sinalizadores de qualidade de importantes 
aspectos da realidade escolar. Esses indicadores são avaliados por perguntas, as respostas a essas perguntas permitem a avaliação da qualidade da escola quanto àquele indicador e a avaliação dos indicadores leva à avaliação da dimensão.

Ressalta-se que o conceito de qualidade é dinâmico e reconstruído constantemente, assim a qualidade na escola depende de fatores diversos e do contexto sociocultural em que cada escola se insere. É importante que os resultados desses indicadores sejam socializados com toda a comunidade escolar, para que juntos, pensem em ações para solucionar os principais desafios detectados nas dimensões, no sentido de promover a melhoria da qualidade da escola.

A fim de maximizar a confiabilidade dos resultados obtidos nessa pesquisa, tem-se, como procedimento, a realização de um instrumento de registro das observações, onde serão feitas as anotações de fatos relevantes ao estudo. 


\section{Referências:}

ALVES, Maria Jacqueline. Perfil do Jovem Trabalhador da Educação de Adolescentes, Jovens e Adultos. Monografia (especialização), Instituto Federal de Educação, Ciências e Tecnologia de Goiás-IFG, Goiânia, 2009.

ANTUNES, Ricardo. A dialética do trabalho: escritos de Marx e Engels. São Paulo: Expressão Popular, 2004.

ARROYO, Miguel Gonzáles. Educação de jovens-adultos: um campo de direitos e de responsabilidade pública. In: SOARES, Leôncio; GIOVANETTI, Maria Amélia; GOMES, Nilma Lino. (Org.). Diálogos na Educação de Jovens e Adultos. p. 24. Belo Horizonte: Autêntica, 2006.

ARRUDA, Marcos. Redes, educação e Economia Solidária: novas formas de pensar a educação de jovens e adultos. In: KRUPPA, Sonia M. Portella. (Org.). Economia solidária e educação de jovens e adultos. p.37. Brasília: Inep, 2005.104p.

BRASIL. Secretaria de Educação Continuada, Alfabetização e Diversidade. Documento Base Nacional Preparatório à VI Confintea (Conferência Internacional de Educação de Adultos), Brasília, set. 2008.

BRASIL. Documento Base. Programa Nacional de Integração da Educação Profissional com a Educação Básica na Modalidade de Educação de Jovens e Adultos: Formação Inicial e Continuada / Ensino Fundamenta Brasília: MEC/ SETEC, 2007. Disponível $<$ http://portal.mec.gov.br/setec/arquivos/pdf2/proeja_medio.pdf> Acesso em 08 de abril de 2010

COSTA, Cláudia B. O trabalhador-aluno da Eaja: desafios no processo ensinoaprendizagem, 2008. Dissertação (mestrado), Universidade Católica de Goiás.(UCG),Goiânia.

FREIRE, Paulo. Pedagogia do oprimido. 20ª ed. Rio de Janeiro: Paz e Terra, 1987.

Pedagogia da Esperança: um encontro com a pedagogia do oprimido. Rio de Janeiro: Paz e Terra, 1994, p. 83 a 136.

GOIÂNIA. Secretaria Municipal de Educação. Proposta Político Pedagógica para o Ensino Fundamental de Adolescentes, Jovens e Adultos da Rede Municipal de Goiânia 2009 (versão preliminar). Goiânia. 
ANEXOS 


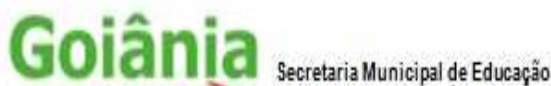 \\ Departamento Pedagógico \\ O futuro se faz agora Divisão de Educação Fundamental de Adolescentes, Jovens e Adultos

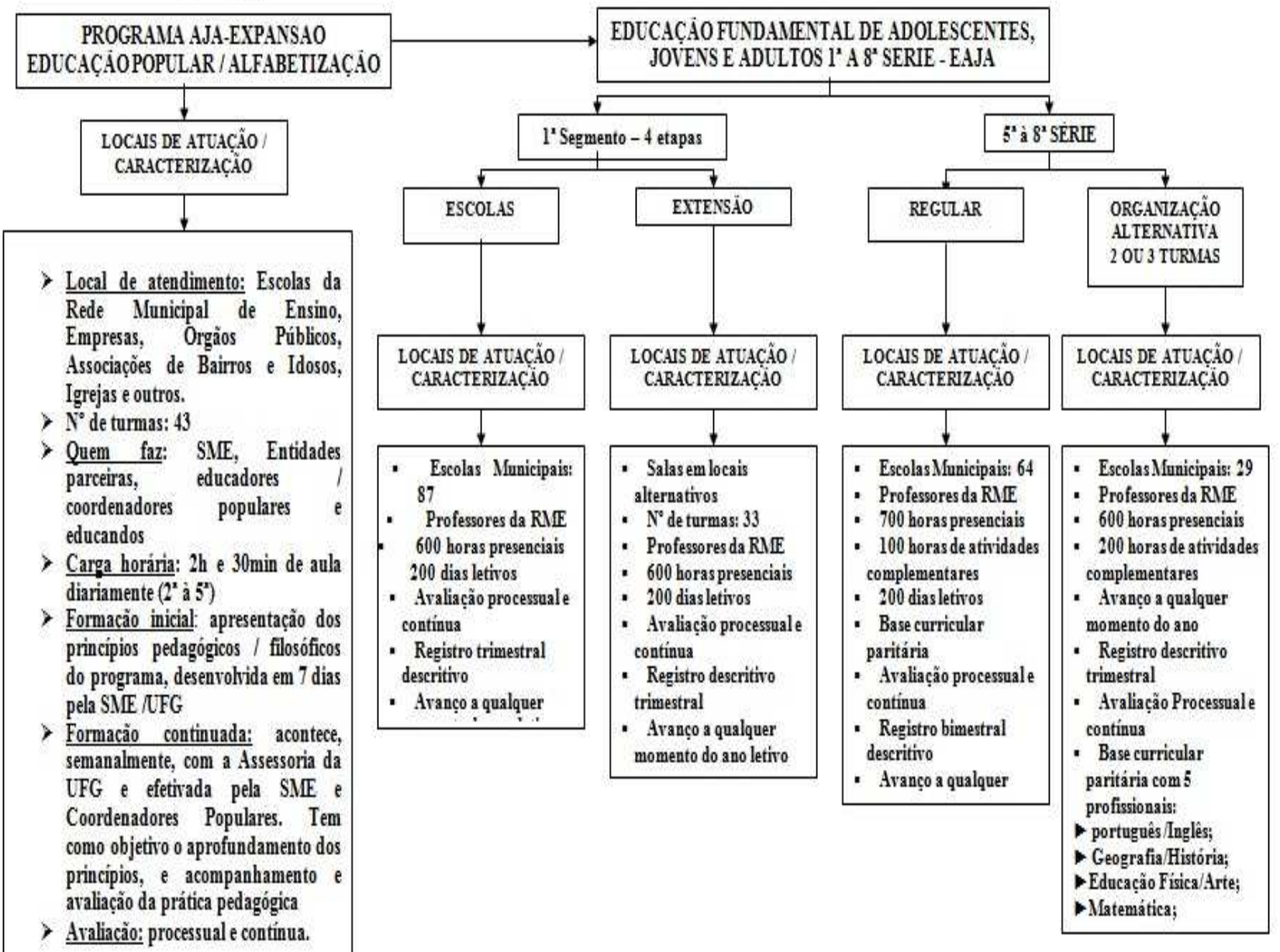




\section{notase \\ Golîni \\ DEPARTAMENTO PEDAGÓGICO \\ UNIDADE REGIONAL DE EDUCAÇÃO JARBAS JAYME \\ AÇÕES PARA OS ACOMPANHAMENTOS E PARA O TRABALHO DA EQUIPE DA EAJA - I TRIMESTRE/2010}

\begin{tabular}{|c|c|}
\hline MÊS & AÇÕES \\
\hline $\begin{array}{l}\text { Janeiro/ } \\
\text { Fevereiro }\end{array}$ & $\begin{array}{l}\text { - Realizar estudo/encontro semanal da equipe da EAJA com a coordenação da URE JJ às } \\
\text { quintas-feiras; } \\
\text { - Orientar a realização do diagnóstico inicial da aprendizagem e do perfil dos educandos; } \\
\text { - Acompanhar junto à coordenação o planejamento dos professores no que se refere ao } \\
\text { diagnóstico inicial nos componentes curriculares; } \\
\text { - Discutir e propor ações/intervenções para a utilização efetiva desse diagnóstico na } \\
\text { (re)construção curricular da EAJA; } \\
\text { - Dialogar com a escola sobre a planilha para a correção do diagnóstico da leitura e da } \\
\text { escrita, e acompanhar esse processo e sua sistematização; } \\
\text { - Auxiliar a (re)construção da proposta de leitura e escrita da UE; } \\
\text { - Orientar e subsidiar a elaboração do Projeto Político-Pedagógico da escola; } \\
\text { - Acompanhar a elaboração do Plano de Ação de estudo e implementação do PPP da } \\
\text { EAJA; } \\
\text { - Auxiliar a escola na definição dos critérios para o avanço, orientando a realização desse, } \\
\text { da classificação e da reclassificação inicial; } \\
\text { - Sugerir ações para a realização das Atividades Complementares; } \\
\text { - Orientar a cerca da Complementação de carga horária; } \\
\text { - Retomar o estudo dos Cadernos de EJA, orientando sua utilização no cotidiano da EAJA } \\
\text { (iniciando com o estudo do Caderno Identidade dos Alunos e Alunas de EJA); } \\
\text { - Discutir com a escola sobre a importância do professor padrinho e orientar a escolha do } \\
\text { mesmo; } \\
\text { - Estudar com as coordenadoras pedagógicas os projetos da URE para, a partir desses } \\
\text { auxiliar na construção de projetos UE) coerente com a realidade da EAJA; } \\
\text { - Apresentar à escola as orientações elaboradas pelos apoios pedagógicos da URE para o } \\
\text { trabalho pedagógico com as temáticas: planejamento, avaliação, relação com a } \\
\text { comunidade, intervenções pedagógicas, organização escolar. }\end{array}$ \\
\hline Março & $\begin{array}{l}\text { - Realizar estudo/encontro semanal da equipe da EAJA com a coordenação da URE JJ às } \\
\text { quintas-feiras; } \\
\text { - Orientar e subsidiar a elaboração do Projeto Político-Pedagógico da escola; } \\
\text { - Acompanhar as ações de implementação da P.P.P da EAJA; } \\
\text { - Discutir e propor intervenções/reflexões para a efetivação da recuperação paralela bem } \\
\text { como da concepção de avaliação na EAJA; } \\
\text { - Acompanhar e orientar as intervenções do professor- padrinho e orientar o processo de } \\
\text { escolha dos representantes de sala; } \\
\text { - Acompanhar de forma sistemática o planejamento dos professores com a coordenação; } \\
\text { - Fazer a leitura das fichas de avaliação descritiva do terceiro trimestre de } 2009 \text {, com o } \\
\text { intuito de orientar no preenchimento das fichas do primeiro trimestre. }\end{array}$ \\
\hline Abril & $\begin{array}{l}\text { - Realizar estudo/encontro semanal da equipe da EAJA com a coordenação da URE JJ às } \\
\text { quintas-feiras; } \\
\text { - Realizar estudo com a coordenação sobre a Concepção de Avaliação da EAJA } \\
\text { diferenciando Classificação de Avaliação; } \\
\text { - Acompanhar de forma sistemática o planejamento dos professores com a coordenação; } \\
\text { - Incentivar a realização das assembléias de turma e a participação dos educandos no } \\
\text { Conselho de Classe; } \\
\text { - Orientar e subsidiar a elaboração do Projeto Político-Pedagógico da escola; } \\
\text { - Acompanhar as ações de implementação da P.P.P da EAJA; } \\
\text { - Orientar a realização do mapeamento da aprendizagem do primeiro trimestre/bimestre. }\end{array}$ \\
\hline
\end{tabular}




\section{RELATÓRIO DE ACOMPANHAMENTO}

Data: $21 / 01 / 2010$

Local: Escola Municipal Renascer

Responsável (eis) URE: Angelita, Deliane, Raph, Marcelo e Rafael

Responsável (eis) pela informação: Diretor Cairo

Turno de realização do acompanhamento: Noturno

Objetivo: Dar boas vindas ao coletivo e proceder algumas orientações referentes ao inicio do ano letivo e realizar o acompanhamento Pedagógico.

\section{Síntese de Acompanhamento:}

Durante o acompanhamento foram tratados os seguintes assuntos:

Apresentação do apoio pedagógico professor Rafael para a Unidade Escolar: comparecemos à UE com objetivo de dar boas vindas ao coletivo que ora inicia o trabalho pedagógico neste ano. Oportunamente, apresentamos enquanto equipe pedagógica da EAJA da URE Jarbas Jayme. A mesma equipe apresentou o apoio pedagógico que acompanhará a escola, para o grupo diretivo, o grupo docente e demais servidores da instituição escolar. O apoio pedagógico Rafael disponibilizou para auxiliar sempre que se fizer necessário e possível as necessidades da Unidade Educacional;

- Quanto à matrícula: foi esclarecido que apenas educandos acima de 15 anos podem se matricular na EAJA. Educandos menores de 15 anos só podem ser matriculados com autorização expressa do Juiz da Infância e Juventude e chegará com encaminhamento da SME;

- $\quad$ Proposta Pedagógica da EAJA - Em complementação às sugestões da Divisão de Educação Fundamental de Adolescentes, Jovens e Adultos (DEF-AJA), orientamos, para a 
dinâmica do planejamento inicial de 2010, que esta Instituição Educacional elaborasse um plano de ação de estudo e implementação da nova Proposta Político-Pedagógica da EAJA (versão preliminar). Este deve estar registrado no PPP da Unidade Educacional. Ressaltamos a importância do mesmo ser de conhecimento de todos os envolvidos (professores, funcionários administrativos, secretário(a), diretor(a) e educandos). Foi realizada uma breve discussão a respeito da proposta, principalmente no que se referia à estrutura do $1^{\circ}$ segmento. Como se deu e o porquê.O apoio Rafael colocou sobre a importância deste momento de reflexão a respeito da proposta e sobre a concepção do educando trabalhador, de modo melhor atendê-lo.

- $\quad$ Organização do Trabalho Pedagógico: orientamos a U.E sobre a dinâmica do planejamento e trabalho inicial (PPP, diagnóstico inicial, metodologia).

\section{Considerações sobre classificação, reclassificação e avanço na EAJA de 1a à}

8a série: esclarecemos que este movimento difere de uma proposta de suplência, onde todos os(as) educando(as) passariam trimestralmente ou semestralmente por avaliações pré-estabelecidas, correspondentes a conteúdos condensados para os períodos definidos. $O$ que propomos é o respeito às individualidades e, portanto, o avanço e a reclassificação só serão aplicados para educandos(as) que de fato demonstrarem 0 desenvolvimento/experiência previstas no processo de ensino regular proposto pela Secretaria Municipal de Educação de Goiânia. Os apoios Raph e Deliane pontuaram que o avanço na Educação de Adolescentes, Jovens e Adultos (após 31/03) se dá a qualquer momento do ano letivo mediante constatação do coletivo de que o educando(a) demonstra desenvolvimento/ experiência que assegurem seu ingresso na série seguinte.

Goiânia, 21 de janeiro de 2010. 
Prefeitura SECRETARIA MUNICIPAL DE EDUCAÇÃO

Golânia DEPARTAMENTO PEDAGóGICO

UNIDADE REGIONAL DE EDUCAÇÃO JARBAS JAYME

RELATÓRIO DE ACOMPANHAMENTO

Data: 20/ 04/ 2010 ( $3^{\text {a }}$ feira)

ESCOLA: E.M.

Local: UNIDADE REGIONAL DE EDUCAÇÃO JARBAS JAYME - URE JJ

Apoios da URE JJ: Deliane de Morais, Marcelo Rodrigues e Rafael Vieira

Coordenador (a) Pedagógico (a)/ U.E:

Turno de realização do acompanhamento: NOTURNO

Objetivos: Realizar acompanhamento às atividades pedagógicas desenvolvidas pela U.E.;

Reunir com coordenadores pedagógicos para proceder algumas orientações relevantes ao trabalho pedagógico na EAJA;

\section{Síntese do acompanhamento/ Reunião:}

- PROJETO: Apresentamos aos coordenadores pedagógicos uma síntese do Projeto de Intensificação do Processo de Ensino/ Aprendizagem da Educação de Adolescentes, Jovens e Adultos - EAJA, que foi elaborado visando mobilizar as escolas no sentido de uma ressignificação das práticas pedagógicas para o desenvolvimento de um ensino, de fato qualitativo, que consiga apreender as demandas objetivas e subjetivas dos educandos da EAJA. Com os coordenadores, a apresentação do projeto foi realizada focando nos objetivos e ações a serem desenvolvidas na EAJA, pela DEF-AJA, UREs e Unidades Educacionais.

- DIAGNÓSTICO: Dialogamos sobre o instrumento de sistematização do diagnóstico da EAJA, orientando os coordenadores sobre o preenchimento do instrumento e o Plano de Ação, destacando os seguintes pontos:

$\checkmark$ Dados - preencher todos os campos do documento com os dados necessários ao diagnóstico, conforme orientações já encaminhadas à U.E e reafirmadas nesta reunião;

$\checkmark$ Plano de Ação - Elaborar o Plano de Ação em consonância com a PPP da EAJA e o plano de ação da coordenação pedagógica;

$\checkmark$ Dificuldades apresentadas em cada Componente Curricular: Escrever, de forma sucinta, as principais dificuldades de aprendizagem dos educandos em cada Componente Curricular (oralidade, leitura, produção de textos, interpretação, raciocínio lógico, reconhecimento das linguagens específicas das áreas de conhecimento e outros).

$\checkmark$ Ações pedagógicas do coletivo com o objetivo de superar as dificuldades: Relacionar ações que promovam a resolução ou minimização das dificuldades dos educandos.

- AVALIAĊ̃̃O: Discutimos com os coordenadores sobre a elaboração da Ficha de Avaliação Descritiva da EAJA orientando-os sobre o registro e outros aspectos importantes da Avaliação dentro do processo de ensino/ aprendizagem de cada sujeito da EAJA. Na oportunidade discutimos sobre o texto AVALIAÇÃO, elaborado pela URE Jarbas, para subsidiar a discussão e estudo do coletivo de professores sobre o processo avaliativo. Pontuamos ainda sobre a necessidade de estudo da PPP da EAJA (RME), com enfoque na Concepção de Avaliação da EAJA, diferenciando Classificação de Avaliação. 


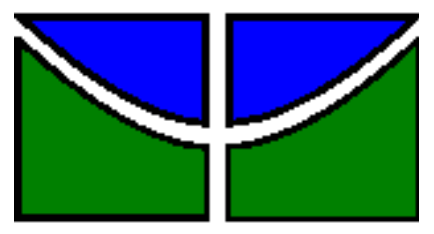

\section{UNIVERSIDADE DE BRASÍLIA \\ Faculdade de Educação - UAB/UnB/ MEC/SECAD \\ Curso de Especialização em Educação na Diversidade e Cidadania, com Ênfase em EJA}

\section{TERMO DE CONSENTIMENTO LIVRE E ESCLARECIDO}

Você está sendo convidado (a) para participar, como voluntário, em uma pesquisa. Após ser esclarecido (a) sobre as informações a seguir, no caso de aceitar fazer parte do estudo, assine ao final deste documento, que está em duas vias. Uma delas é sua e a outra é do pesquisador responsável. Em caso de recusa você não será penalizado (a) de forma alguma.

\section{INFORMAÇÕES SOBRE A PESQUISA:}

Título do Projeto de Intervenção Local: O mundo do trabalho e a educação de adolescentes, jovens e adultos na rede municipal de Goiânia: possibilidades e desafios.

Pesquisadores responsáveis: Rafael Vieira de Araújo e Margareth Matias Porfírio Machado. Telefones para contato: (62) 91520312 e (62) 8115-9901

Este projeto de intervenção local tem como intuito analisar a Proposta Político Pedagógica (P.P.P) da EAJA da Rede Municipal de Educação de Goiânia, observando a realidade vivenciada nas escolas por educandos trabalhadores e educadores da EAJA, no sentido de levantar contribuições para essa modalidade da Educação.

Tendo em vista essa rápida explanação acima, peço-o a vos autorização para fazer a entrevista de caráter semi-estruturada, que será de grande contribuição e relevância social, contribuindo para o desenvolvimento educacional..

O período da pesquisa se estende até junho de 2010, prazo final para a conclusão da pesquisa e defesa do PIL. A sua identidade é de caráter sigiloso e jamais será revelada, bem como você tem o direito de retirar o seu consentimento a qualquer tempo.

RAFAEL VIEIRA de ARAÚJO e MARGARETH MATIAS PORFÍRIO MACHADO

\section{CONSENTIMENTO PARA PARTICIPAÇÃO DA PESSOA COMO SUJEITO}

Eu, RG: abaixo assinado, concordo em participar do estudo, como sujeito. Fui devidamente informado (a) e esclarecido(a) pelo pesquisador Rafael Vieira de Araújo sobre a pesquisa. Foi-me garantido que posso retirar meu consentimento a qualquer momento, sem que isto leve a qualquer penalidade.

Goiânia, de de 2010.

Assinatura: 


\section{Prefeitura ESTADO DE GOIÁS \\ PREFEITURA MUNICIPAL DE GOIÂNIA \\ SECRETARIA MUNICIPAL DE EDUCAÇÃO \\ DEPARTAMENTO PEDAGÓGICO \\ UNIDADE REGIONAL DE EDUCAÇÃO JARBAS JAYME}

\section{Análise do Projeto-Político Pedagógico/2010}

INSTITUIÇÃO

APOIO: Rafael Vieira de Araújo

\section{ASPECTOS RELEVANTES}

1. Concepção da EAJA - Sujeitos (adolescentes, jovens e adultos). Especificidades da EAJA.

2. Currículo (de acordo com a PPP da EAJA):

3. Diagnóstico (interesses e necessidade dos educandos e aprendizagem; este fica claro no PPP)

4. Ações / Metas para EAJA (redução da evasão, melhoria do processo ensino aprendizagem)

5. Proposta de Leitura e Escrita / Alfabetização, Plano de ação para o trabalho nos diferentes Componentes Curriculares e/ou Ârea de Conhecimento (Organização Alternativa)

6. Proposta de Planejamento (como este acontecerá?)

Foi contemplada (p.51)

7. Proposta de realização das Atividades Complementares.

8. Avaliação (Avanço, Classificação, Reclassificação, Recuperação Paralela).

9. Proposta de realização do Conselho de Classe (assembléia de turma, representante de turma, etc.)

10. Plano de Ação Estudo e Implementação da Proposta da EAJA da RME.

11. Proposta de realização da complementação de carga horária.

10. Observações:

Parecer:

Goiânia, de de 2010. 


\section{INDICADORES DA QUALIDADE NA EDUCAÇÃO DE ADOLESCENTES JOVENS E ADULTOS E EFETIVAÇÃO DA PROPOSTA POLÍTICO- PEDAGÓGICA DA RME}

Escola:

Este instrumento foi construído com base no documento do MEC "Indicadores da Qualidade na Educação" (AÇÃO EDUCATIVA, São Paulo, 2007. $3^{\text {a }}$ Edição ampliada) e na Proposta Político-pedagógica da EAJA da Rede Municipal de Educação de Goiânia (Versão Preliminar, 2009). Os objetivos desse instrumento são: ajudar a comunidade escolar a avaliar e melhorar a qualidade da educação de sua escola e auxiliar na garantia da efetivação da proposta da EAJA da RME.

Para que toda a comunidade escolar reflita no sentido de melhorar a qualidade da educação de sua escola, foram definidas seis dimensões as quais representam os elementos de qualidade considerados para Educação de Adolescentes Jovens e Adultos, sendo elas: Ambiente Educativo, Prática Pedagógica e Avaliação, Ensino e Aprendizagem da Leitura e da Escrita, Gestão Escolar Democrática, Acesso e Permanência na Escola, Implementação da Proposta Político-Pedagógica da EAJA. Cada dimensão é constituída por um grupo de indicadores que representam sinalizadores de qualidade de importantes aspectos da realidade escolar. Esses indicadores são avaliados por perguntas, as respostas a essas perguntas permitem a avaliação da qualidade da escola quanto àquele indicador e a avaliação dos indicadores leva à avaliação da dimensão.

Ressalta-se que o conceito de qualidade é dinâmico e reconstruído constantemente, assim a qualidade na escola depende de fatores diversos e do contexto sociocultural em que cada escola se insere. É importante que os resultados desses indicadores sejam socializados com toda a comunidade escolar, para que juntos, pensem em ações para solucionar os principais desafios detectados nas dimensões, no sentido de promover a melhoria da qualidade da escola.

Foram adotados os seguintes ícones:

^ Práticas, atitudes ou situações já consolidadas na escola;

$\rightarrow$ Práticas, atitudes ou situações que ocorrem, mas não podem ser consideradas recorrentes ou consolidadas;

$\downarrow$ Práticas, atitudes ou situações inexistentes ou quase inexistentes na escola. 


\section{RESPEITO AO OUTRO}

\section{Dimensão 1: AMBIENTE EDUCATIVO}

Os alunos tratam bem os professores e os funcionários da escola?

Os alunos são tratados com respeito e atenção por todos os profissionais da escola?

As pessoas que trabalham na escola se sentem respeitadas e valorizadas entre si e pelos alunos?

2. DISCIPLINA E TRATAMENTO ADEQUADO AOS CONFLITOS QUE OCORREM NO DIA-A-DIA DA ESCOLA

As regras de convivência são claras, conhecidas e respeitadas por toda a comunidade escolar?

Os alunos participam da elaboração das regras de convivência na escola?

As regras estabelecem direitos e deveres para todos (alunos, professores, diretor, demais profissionais da escola)?

Os profissionais da escola (diretor, professores, funcionários administrativos) procuram resolver os conflitos que surgem entre as pessoas no ambiente escolar com base no diálogo?

Os professores e coordenadores desenvolvem atividades que estimulem os alunos a resolver os conflitos do cotidiano escolar com base no diálogo?

Ações para solucionar os principais problemas detectados na dimensão.

\section{Dimensão 2: PRÁTICA PEDAGÓGICA E AVALIAÇÃo}

1. PROPOSTA PEDAGÓGICA DA EAJA NA ESCOLA

Professores, alunos, diretor, funcionários e outros membros da comunidade escolar participaram ativamente da elaboração do projeto político-pedagógico da escola?

A escola possui uma proposta pedagógica que considera as necessidades, os interesses e o perfil dos sujeitos da EAJA?

A práxis pedagógica tem como referência a Proposta Pedagógica da EAJA?

A escola utiliza os resultados da avaliação diagnóstica de leitura e escrita e dos componentes curriculares para a (re)construção curricular?

A escola faz com os educandos o levantamento dos temas que serão contemplados na Proposta Pedagógica da EAJA?

As atividades complementares têm como objetivo a realização de atividades de cunho esportivo, culturais, visitas pedagógicas e outras?

\section{PLANEJAMENTO}


Nos planejamentos pedagógicos, são definidas as ações a serem realizadas nas salas de aula e na escola para melhorar a aprendizagem?

Os professores planejam regularmente suas aulas?

Os professores frequentemente trocam idéias entre si para planejar as aulas?

Os professores ouvem e consideram opiniões e sugestões dos alunos para planejar suas aulas?

O planejamento prevê o uso de diferentes recursos pedagógicos (Internet, jornais, revistas, livros diversos, obras de arte, filmes) em sala de aula?

Os professores definem os objetivos no início do trimestre/bimestre e entregam à coordenação pedagógica para acompanhamento?

A coordenação pedagógica acompanha quinzenalmente o planejamento dos professores?

As discussões que acontecem nos momentos de planejamento dos professores com a coordenação são registradas?

\section{CONTEXTUALIZAÇÃO}

Professores e alunos realizam atividades de estudo do ambiente da comunidade em que a escola está inserida?

A escola promove visitas no bairro e na cidade para que os alunos conheçam e aprendam a usar os recursos públicos da região (postos de saúde, hospitais, parques, praças, monumentos, museus, bibliotecas, centros culturais, Conselho Tutelar, Juizado e outros)?

Os professores relacionam os conteúdos a serem trabalhados na sala de aula com a realidade da comunidade a qual o educando está inserido?

Temáticas importantes para o processo educativo de adolescentes, jovens e adultos, são tratadas com os alunos (gravidez na adolescência, abuso de álcool e drogas, emprego e desemprego, tráfico de drogas, sexualidade, namoro, relacionamento com os pais, amizade, direitos trabalhistas, o trabalho no mercado informal, relações intergeracionais, violência doméstica, pedofilia e outras)?

O currículo da escola tenta fazer a ligação da EAJA com a formação profissional em atendimento aos interesses dos educandos trabalhadores?

\section{FORMAS VARIADAS DE AVALIAÇÃO DOS ALUNOS}

Os professores fazem uso de diferentes instrumentos avaliativos (provas, trabalhos, seminários, pesquisas, relatórios e outros) ?

Os alunos são informados das razões pelas quais tiram esta ou aquela nota ou por que foram aprovados ou reprovados?

Os alunos são orientados pelos professores a fazer auto-avaliação (falar, escrever, expressar o que aprenderam)?

Os alunos são informados sobre os conteúdos nos quais progrediram e em quais precisam estudar e avançar mais?

A escola realiza Assembléia de Turma com os educandos anteriormente ao Conselho de Classe?

Os critérios para a realização do avanço são discutidos e definidos juntamente com os alunos?

Os educandos participam dos momentos do conselho de classe?

A ficha de avaliação descritiva é socializada e discutida com todos os alunos?

\section{MONITORAMENTO DA PRÁTICA PEDAGÓGICA E DA APRENDIZAGEM DOS ALUNOS}

Os professores observam a progressão dos alunos e quais as dificuldades de cada um 
deles (corrigem trabalhos, circulam pela classe enquanto os alunos estão fazendo suas atividades, incentivam os alunos a fazer perguntas e tirar dúvidas)?

A escola promove reuniões periódicas entre os professores, coordenadores e o diretor para discutir assuntos relativos ao cumprimento do planejamento e avaliar o processo de aprendizagem dos alunos?

No decorrer do bimestre/trimestre os professores reavaliam o processo ensino aprendizagem para programar e realizar a recuperação paralela?

As decisões sobre a aprovação ou a reprovação de alunos são discutidas por todos os professores?

Existe algum procedimento formalizado para avaliar o resultado do trabalho da equipe pedagógica da escola?

Ações para solucionar os principais problemas detectados nessa dimensão.

\section{Dimensão 3: ENSINO E APRENDIZAGEM DA LEITURA E DA ESCRITA}

\section{ORIENTAÇÕES PARA A ALFABETIZAÇÃO/ LEITURA E ESCRITA}

A escola possui uma proposta de alfabetização?

Os professores responsáveis pela alfabetização inicial elaboram e realizam seus planos de aula considerando as orientações da proposta de alfabetização e a realidade dos educandos da EAJA?

A escola desenvolve um trabalho específico com a leitura e a escrita?

\section{EXISTÊNCIA DE PRÁTICAS ALFABETIZADORAS E AMPLIAÇÃO DAS CAPACIDADES DE LEITURA E} ESCRITA DOS EDUCANDOS DA EAJA

Os alunos leem/usam diariamente materiais de leitura disponibilizados nas salas de aula de diferentes gêneros textuais e compativeis com a sua faixa etária e seu nivel de aprendizagem?

Os alunos participam diariamente de atividades planejadas para a aprendizagem progressiva da leitura e da escrita?

Semanalmente, os alunos participam de projetos ou atividades nas quais podem conhecer e exercitar os diferentes usos da leitura e da escrita no dia-a-dia?

Os professores desenvolvem atividades para ajudar os estudantes na compreensão e na interpretação dos textos lidos?

A escola valoriza os textos elaborados pelos alunos?

Os professores têm o hábito de ler para e com os alunos (obras literárias, notícias, textos, artigos diversos, e outros?

\section{ATENÇÃO AO PROCESSO DE ALFABETIZAÇÃO E LETRAMENTO}

A escola faz uma avaliação diagnóstica com todos os alunos logo que começam no primeiro segmento para saber quais são seus conhecimentos sobre a leitura e a escrita 
naquele momento e assim planejar melhor as aulas de alfabetização?

A escola possui uma prática alfabetizadora que garante que até o final do primeiro segmento a maioria dos alunos tenham o domínio básico da leitura e da escrita?

\section{AMPLIAÇÃO DAS CAPACIDADES DE LEITURA E ESCRITA}

Os professores incentivam os alunos na leitura de livros, que poderão ser usados em atividades relacionadas aos conteúdos escolares?

Todos os professores desenvolvem seu trabalho tendo como foco a leitura e a escrita?

Os professores de todos os componentes curriculares realizam regularmente atividades que envolvem o planejamento, a produção e a revisão dos textos dos alunos?

A escola respeita a variedade linguística do educando, marcada pelas suas experiências de vida e, ao mesmo tempo, possibilita a apropriação da variedade padrão da língua?

\section{ACESSO E BOM APROVEITAMENTO DA SALA DE LEITURA E DO AMBIENTE INFORMATIZADO}

Os alunos fazem uso da sala de leitura em horário letivo pelo menos uma vez por semana, fazendo pesquisas, leituras e outras atividades?

Os alunos fazem empréstimos de livros do acervo da escola (para ler em casa ou na sala de aula)?

Os alunos usam computadores e a Internet para aprimorar a leitura e a escrita pelo menos uma vez por semana, durante o horário das aulas?

É prioridade da escola a aquisição de livros, vídeos, documentários direcionados para a EAJA?

Ações para solucionar os principais problemas detectados nessa dimensão.

Açôes para solucionar os principais problemas detectados nessa dimensão.

Dimensão 4: GESTÃO ESCOLAR DEMOCRÁTICA

1. COMPROMETIMENTO E PARTICIPAÇÃO EFETIVA DA EQUIPE DIRETIVA, PROFESSORES E EDUCANDOS DA EAJA

A direção repassa as informações oriundas da SME ao coletivo da EAJA?

A equipe diretiva e a docente demonstram comprometimento e conhecimento da proposta da EAJA descrita no PPP da escola?

A direção, coordenação e professores cumprem rigorosamente os compromissos relacionados à EAJA (carga horária de trabalho semanal, reuniões com a DEF-AJA e URE, reuniões de planejamento, Conselho de Classe, eventos, orientações à equipe docente - direção e coordenação)?

Existem espaços para que alunos, professores, funcionários e diretor discutam e decidam os encaminhamentos relativos ao melhor andamento da EAJA na escola?

Os eventos (gincanas, passeios, festas, formaturas, e outros) realizados pela escola são organizados (dia da semana, horário) de forma a garantir a presença dos educandos da 
EAJA, mesmo daqueles desprovidos de recursos financeiros?

É realizada a escolha de representante de sala e este participa da tomada de decisões na escola e ajuda os alunos a se organizarem?

Os professores entregam os documentos (diários, fichas, avaliações, notas e outros) em tempo hábil para coordenação?

\section{ASSIDUIDADE DA EQUIPE ESCOLAR}

As faltas de coordenadores, professores ou funcionários é um problema discutido por toda a comunidade escolar (incluindo pais e alunos) quando estão atrapalhando o aprendizado e o andamento das atividades educativas?

Os professores começam e terminam as aulas pontualmente?

Os demais profissionais da escola também cumprem sua jornada com pontualidade?

As reuniões pedagógicas começam e terminam na hora marcada?

\section{FORMAÇÃO CONTINUADA}

Os professores e a coordenação sempre se reúnem para a discussão dos planos de aula, para a avaliação da prática e para estudos (reuniões pedagógicas)?

O coordenador tem oferecido subsídios aos professores de forma a contribuir com a melhoria da prática pedagógica da EAJA?

Professores e coordenadores participam de formações especificas para o trabalho com a EAJA, oferecidas pelo CEFPE: GTE de coordenador, cursos fora e no horário de trabalho, palestras, colóquios e outros?

Ações para solucionar os principais problemas detectados nessa dimensão. 


\section{Dimensão 5: ACESSO E PERMANÊNCIA NA ESCOLA}

\section{ATENÇÃO ESPECIAL AOS ALUNOS QUE FALTAM}

A coordenação e os professores procuram compreender as causas das faltas dos alunos? A escola possui alguma maneira de atender os alunos com maior número de faltas, buscando resolver esse problema ou amenizá-lo, para que o aluno não fique prejudicado em relação à sua aprendizagem?

\section{PREOCUPAÇÃO COM O AFASTAMENTO E A EVASÃO DOS EDUCANDOS}

A equipe diretiva, professores e coordenação fazem o levantamento da quantidade de alunos que se evadem ou se afastam da escola?

A equipe diretiva, professores e coordenação buscam compreender as causas do afastamento e da evasão?

A escola adota alguma medida para trazer de volta alunos que se evadiram ou se afastaram da escola?

As medidas adotadas pela escola para minimizar a evasão e o afastamento têm gerado bons resultados?

\section{ATENÇÃO ESPECIAL AOS ALUNOS COM ALGUMA DEFASAGEM DE APRENDIZAGEM}

No dia-a-dia, os professores dão atenção individual àqueles alunos que apresentam dificuldades de aprendizagem?

A escola oferece oportunidades especiais para alunos que têm dificuldades de aprendizagem (como atividades diferenciadas em sala, recuperação paralela individualizada durante as aulas, reagrupamento e/ou oficinas pedagógicas de acordo com as dificuldades dos alunos)?

Caso ações como estas sejam realizadas, elas conseguem fazer com que os alunos melhorem seu nivel de aprendizagem?

A coordenação tem conhecimento de quais são as disciplinas que mais reprovam e utilizam tal informação para reavaliar o processo de ensino?

Ações para solucionar os principais problemas detectados nessa dimensão.

\section{Dimensão 6: IMPLEMENTAÇÃO DA PROPOSTA POLÍTICO PEDAGÓGICA DA EAJA/ RME}

A equipe pedagógica (diretor, coordenadores e professores) e funcionários administrativos conhecem a PROPOSTA POLÍTICO PEDAGÓGICA DA EAJA/ RME, Versão Preliminar/2009?

A escola elaborou o plano de ação para estudo e implementação da proposta?

O cronograma de estudo da Proposta prevê momentos de discussão coletiva ao longo do ano letivo?

Os momentos de estudo têm contemplado a participação de todos os sujeitos da EAJA

(professores, funcionários e alunos?) 
Na parte de concepção da EAJA, no PPP da U.E, os eixos e princípios da Proposta da RME foram referenciais para elaboração?

Ao definir os objetivos dos componentes curriculares, os professores consultaram a Proposta da RME?

$\mathrm{Na}$ construção da proposta de alfabetização, leitura e escrita os professores fundamentaram-se na Proposta, no que se refere ao Primeiro Segmento?

Na EAJA $5^{\text {a a }} 8^{\text {a }}$ Organização Alternativa, os professores responsáveis pela dinamização e os professores dos componentes curriculares se organizam para o repasse/planejamento antecipado das atividades e/ou conteúdos que serão desenvolvidas nesses momentos?

A dinamização acontece de forma a garantir a base paritária dentro do período previsto, para o fechamento dessa no horário rotativo?

O horário rotativo é organizado em uma seqüência de dias que garanta ao máximo a paridade em todos os componentes curriculares?

Nas escolas em que o segundo segmento é organizado com quatro turmas a complementação de carga horária é desenvolvida conforme as orientações da SME?

As atividades complementares (visitas e viagens pedagógicas, torneios esportivos, atividades artísticas e culturais, participação nos Jogos Educacionais, etc.) contam com a participação dos professores?

Esses momentos de atividades complementares com a participação de professores e alunos acontecem ao menos quatro vezes ao ano?

A escola tem servido o lanche no início da aula ou até no máximo às 20 hs?

A U.E tem como prática cotidiana o acolhimento ao educando, objetivando sua permanência e continuidade dos estudos?

É garantido o tempo máximo de 10 min para o recreio, conforme orientado pela SME, com vistas ao cumprimento da carga horária anual de direito do aluno?

Ações para solucionar os principais problemas detectados nessa dimensão.

Apoio Pedagógico:

Data:

/

Diretor (a):

Data:

Coordenador (a):

Data: 


\section{PROPOSTA PEDAGÓGICA DA EAJA VERSÃO PRELIMINAR}

\section{PROPOSTA POLÍTICO-PEDAGÓGICA DA EDUCAÇÃO DE ADOLESCENTES, JOVENS E ADULTOS}




\section{PREFEITO MUNICIPAL DE GOIÂNIA}

Iris Rezende Machado

\section{SECRETÁRIA MUNICIPAL DE EDUCAÇÃO}

Professora Márcia P. Carvalho

\section{DIRETORA DO DEPARTAMENTO PEDAGÓGICO}

Professora Cynthia Regina da Cunha Rocha

\section{CHEFE DA DIVISÃO DE EDUCAÇÃO FUNDAMENTAL DE ADOLESCENTES, JOVENS E ADULTOS \\ Professora Ana Flávia Pereira}

\section{EQUIPE DA DIVISÃO DE EDUCAÇÃO FUNDAMENTAL DE ADOLESCENTES, JOVENS E ADULTOS \\ Professora Cláudia Costa \\ Professora Izabel Maria Damaso Bueno \\ Professora Luiza Pereira Monteiro \\ Professora Margareth Matias Porfírio Machado \\ Professora Márcia Pereira Melo \\ Professora Maria Jacqueline Dias Alves \\ Professor Marco Aurélio Alves Vicente}




\section{ASSESSORIA PEDAGÓGICA}

Professora Dra. Maria Margarida Machado (UFG/Faculdade de Educação)

Professora Dra. Maria Emília Castro Rodrigues (UFG/Faculdade de Educação)

\section{CENTRO DE FORMAÇÃO DOS PROFISSIONAIS DA EDUCAÇÃO "PAULO FREIRE" GRUPO DE TRABALHO E ESTUDO}

Professora Agda Alves de Azevedo Canedos (URE BRASIL)

Professora Christiane de Holanda Camil (EM

Professor Eduardo de Carvalho Ribeiro (CEFPE)

Professora Gler Vanessa Costa Peres (EM

Professora Irene de Assis Pinto (EM

Professor a Jacymara Paiva Junqueira de Souza (EM

Professor Luciano Alves de OliveiraMarco Antônio (EM

Professora Maria Dalva (EM

Professor Marcos Augusto Marques Ataídes (EM

Professora Maria Auxiliadora Dias da Silva Ribeiro (EM

Professora Maria Magdalena Ferreira (URE CENTRAL)

Professora Raph Gomes Alves (URE JARBAS JAYME)

Professora Ronan dos Santos Queiroz (EM

Equipe da Divisão de Educação Fundamental de Adolescentes, Jovens e Adultos 
Índice

Apresentação

1- Justificativa

1.1 Caminho trilhado

1.2- Sujeitos

1.3- Bases legais

2-Organização curricular

2.1-Princípios

2.2-Eixos

2.3- Metodologia

2.4-Avaliação

2.5-Formação

2.6- Orientações

2.6.1- Primeiro segmento

2.6.2- Componentes curriculares no Primeiro e Segundo Segmento

2.7- Estrutura organizacional

3- Referências

4- Anexo 


\section{Apresentação}

\section{Justificativa}

A Educação de Adolescentes, Jovens e Adultos - EAJA, na Rede Municipal de Goiânia - RME, em consonância com a Lei de Diretrizes e Bases da Educação Nacional LDBEN, Lei 9.394/96 em seu art. 37. $\S 1^{\circ}$ e $2^{\circ}$, busca garantir a ampliação do acesso ao processo de escolarização e sua permanência nele, bem como sensibilizar os ainda não alfabetizados deste Município a darem início ao processo de leitura e escrita, na tentativa de promover atitudes social e politicamente comprometidas.

Dados de pesquisas e de escutas realizadas com educandos e professores2 apontam para a necessidade de desenvolvimento de ações que assegurem o atendimento de qualidade aos Adolescentes, Jovens e Adultos que não tiveram escolaridade em tempo regular ou que dela foram excluídos; atender às necessidades e peculiaridades desses educandos e contribuir para a superação da evasão e da cultura de repetência e garantir acesso ao saberes e conhecimentos com condições específicas e indispensáveis para a vida cidadã e para o mundo do trabalho.

A Educação de Adolescentes, Jovens e Adultos - EAJA está intrinsecamente voltada para inclusão de pessoas em contextos: social, econômico, cultural e geracional diferenciados. Nesta perspectiva, ela se relaciona à educação popular ${ }^{3}$, visando a emancipação dos sujeitos. Oferece flexibilidade no horário de início e término da jornada diária, respeitando as condições do educando, sem comprometer a qualidade do ensino ou ferir os dispositivos legais.

É fundante a formação permanente dos educadores.Segundo Machado (2008, p.165) "o descompasso entre a formação do professor e a realidade dos alunos na EJA causou (e tem causado, ainda) situações de difícil solução (...)". Necessário se faz a promoção de formação com momentos de estudo, avaliações e discussões, com envolvimento de todo coletivo da EAJA que contemplem situações de aprendizagens e a reflexão da própria ação, a capacidade de apropriação crítica, a busca de informações, o reconhecimento do trabalho e estratégias que sirvam para a superação dos problemas da prática educativa.

2

Dados Administrativo-Pedagógicos, Projeto Revelando Nossa História, Carta aos Professores, GTE Ressignificando o Trabalho Pedagógico na EAJA e escuta de educandos de $1^{\mathrm{a}}$ à $4^{\mathrm{a}} \mathrm{e}$ Projeto AJA. Ver "Caminho Trilhado"

3 O popular tem a força e o potencial para o reordenamento da teoria educacional. Tal reordenamento implica permanente diálogo, reflexão e reconhecimento que as dimensões do político e do pedagógico encontram-se num mesmo nível de importância, Trindade (2009,p.24). 
Na EAJA um dos desafios encontrados se caracteriza na escassez e produção de material didático-pedagógico destinado a este público. Sua produção torna-se viável, partindo de grupos de estudos e pesquisa nas Unidades Escolares, das experiências e dos trabalhos realizados pelos educandos e educadores.

A Secretaria Municipal de Educação de Goiânia - SME, preocupada com a inclusão educacional e social, se articula para viabilizar atendimento especializado ${ }^{4}$ aos educandos com deficiência, bem como acompanhamento por equipe multidisciplinar, em casos que se fizerem necessário, e para analisar, criteriosamente, a formação de turmas com número elevado desses educandos. Estas ações estão amparadas na Política Nacional de Educação Especial na Perspectiva da Educação Inclusiva, da Secretaria de Educação Especial/MEC, bem como no Decreto Federal $n^{\circ}$ 6.571, de 17 de setembro de 2008, que dispõe da oferta do atendimento educacional especializado aos alunos com deficiência, transtornos globais do desenvolvimento e altas habilidades ou superdotação, matriculados na rede pública de ensino regular e ainda nos demais preceitos legais.

Tecer e implementar a Proposta Político Pedagógica da EAJA a partir da construção coletiva com os educandos e com os profissionais envolvidos nesta modalidade, justifica-se na perspectiva de reafirmar o direito que foi negado aos que foram excluídos ou impossibilitados de escolarização, concebendo o conhecimento a partir da troca de saberes, numa interação entre a teoria e a prática e, sobretudo, pelo reconhecimento do direito à educação e de aprender por toda vida.

\section{1- Caminho trilhado}

A história ${ }^{5}$ da Educação de Jovens e Adultos- EJA, no Brasil, é marcada por constantes tensões, conflitos e proposições no sentido de assegurar a construção de suas políticas públicas. Apesar deste contexto, na SME é possível perceber que as propostas desenvolvidas, a partir de 1990, vêm assegurando aos adolescentes, jovens e adultos o direito ao acesso e continuidade no processo de escolarização.

Neste histórico serão enfatizadas as políticas de Educação de Jovens e Adultos, tendo como marco a década de 1980, haja vista ter sido este período marcado por grandes

4 Considera-se atendimento especializado o conjunto de atividades, recursos de acessibilidade e pedagógicos organizados, institucionalmente, prestado de forma complementar ou suplementar à formação dos alunos no ensino regular.

5 Ver: MACHADO (1997, 2007), HADDAD e DI PIERRO (2000), RODRIGUES (2000) FÁVERO (2004), para aprofundamento de estudos recomenda-se a busca desses autores. 
mobilizações da sociedade civil, por meio de associações, movimentos sociais e populares, sindicatos, entre outros. Essas lutas se materializaram em torno da mobilização de diversos segmentos ligados à Educação, em torno da Assembléia Constituinte (1986-1988). Também serão evidenciadas as experiências ocorridas na SME.

A política que se instaurou a partir de 1980, com o discurso da redemocratização do país, na Educação de Adultos, foi a da garantia de acesso à escola àqueles que dela foram excluídos. Neste contexto, cria-se a Fundação Educar ${ }^{6}$; em substituição ao Mobral, com o objetivo de apoiar e fomentar projetos de educação de jovens e adultos. Porém, tal discurso ainda divergia e se distanciava da realidade do que estava ocorrendo nos Estados e Municípios.

Em 1988 foi promulgada a nova Constituição Federal, instituindo em seu Art. $208^{7}$ a obrigatoriedade do ensino fundamental para todos. Conforme CURY (2000, p. ) “ longe de reduzir a EJA a um apêndice dentro de um sistema dualista pressupõe a educação básica para todos e dentro desta, em especial, o ensino fundamental com seu nível obrigatório (...) ele é para todos e não só para as crianças.” Dessa forma, a incorporação da educação como direito de todos, expressa na lei maior, aponta aos municípios brasileiros a necessidade de revisão em suas formas de atendimento aos sujeitos de direitos, sobretudo dos jovens e adultos.

A Organização das Nações Unidas elegeu o ano de 1990 como Ano Internacional da Alfabetização. Em seguida, aconteceu a Conferência Mundial de Educação com o objetivo de incentivar o desenvolvimento de políticas públicas para esse setor. No âmbito nacional, algumas discussões foram encaminhadas e mais tarde contempladas na Lei de Diretrizes e Bases da Educação Nacional, (BRASIL, 1996) $)^{8}$.

No que se refere à SME, desde a sua criação ${ }^{9}$ atende ao ensino noturno. Conforme Clímaco (1991), em 1961 haviam duas escolas funcionando no terceiro turno e, em 1965, seis escolas no noturno. Os jovens e adultos eram atendidos neste turno, no entanto, não existia

6 De acordo com Machado a (1997, p. 40) "Fundação Nacional de Educação de Jovens e Adultos, conhecida como EDUCAR. Sua diferença fundamental do MOBRAL estava no caráter não executivo, ou seja, cabia à Fundação transferir os recursos necessários à execução de programas de alfabetização e educação básica, bem como sua normalização. Os executores seriam os Estados, Municípios e outras entidades públicas e privadas. A Fundação Educar apoiou entidades que realizavam trabalhos de educação popular e alfabetização em todo o país, como parte integrante do discurso de retomada da democracia, após 20 anos de ditadura."

7 Ver Bases Legais, páginas 21,22,23,24 dessa proposta.

8 Ver Bases Legais, páginas 21,22,23,24 dessa proposta.

9 Nos escritos de Clímaco (1991, p. 66) o ano de 1961 é marcado por uma tentativa de reorganização administrativa do município criando " a Secretaria Municipal de Educação e Cultura (...) Lei de criação n. 1910 de 1/10/1961." 
uma proposta específica para esse grupo. No bojo do processo de redemocratização, a década de 1980 caracterizou-se, na SME, por um quadro de lutas envolvendo sindicatos, associações de pais e mestres e movimento estudantil, objetivando melhores salários, condições de trabalho e investimentos na estrutura física das escolas, além da organização de grêmios estudantis, maior participação da comunidade na escola, entre outros.

Em relação à política de Educação de Jovens e Adultos, em 1992 foi criado um grupo de estudos e elaborado o Projeto Alfabetização e Cidadania, numa parceria entre Universidade Federal de Goiás - UFG e SME, como forma de viabilizar uma educação para adolescentes em situação de risco. Desde então, a SME tem se empenhado na discussão específica sobre a EJA, o que resultou, neste mesmo ano, na criação da primeira equipe do ensino noturno, transformada, em 1995, no Setor de Educação de Adolescentes, Jovens e Adultos. Em 1993 foram incorporados os princípios do Projeto Alfabetização e Cidadania desenvolvido pela UFG, dando origem ao Projeto AJA10. Este Projeto, que existiu por pouco tempo e apenas dentro da UFG, expandiu-se pela SME, com recursos do Tesouro Municipal.

Com a implantação do Projeto AJA, a rede passou a conviver com duas formas de atendimento, sendo uma seriada e outra modulada. Isso desencadeou, em 1994, um processo rico de reflexões sobre as possíveis mudanças que poderiam se efetivar na EAJA. Na tentativa de adequar o atendimento à realidade de seus sujeitos, foram realizados diversos encontros, seminários e reuniões com toda a equipe pedagógica, na perspectiva do amadurecimento das reflexões sobre a especificidade do trabalho com a EAJA.

Com a promulgação da nova LDB/1996, a responsabilidade do ensino fundamental passa para os municípios. Assim, Goiânia buscou a possibilidade de independência, construiu uma autonomia acerca da legislação, que até então era normatizada pelo Conselho Estadual de Educação - CEE. Dessa forma, em 1998, foi criado o Conselho Municipal de Educação - CME, que passou a regulamentar as diretrizes que norteiam o funcionamento desse Sistema Municipal de Ensino, incluindo a EAJA.

Entre as iniciativas para a consecução deste objetivo, de descentralização na educação, destaca-se o Fundo de Manutenção e Desenvolvimento do Ensino Fundamental e de valorização do Magistério - FUNDEF, implantado, nacionalmente, em $1^{\circ}$ de janeiro de

10 Experiência Pedagógica de $1^{a} a ̀$ a $4^{a}$ série do Ensino Fundamental para Adolescentes, Jovens e Adultos: modalidade de caráter experimental que se caracterizou por uma organização por meio de módulos; flexibilidade no período de matrícula dos educandos; avanço a qualquer momento do ano, oficializado trimestralmente; 180 dias letivos com três horas diárias de funcionamento; atividade cultural semanal; reuniões semanais de estudo e planejamento dos professores; reuniões trimestrais de avaliação do projeto como um todo. 
1998, quando passou a vigorar a nova sistemática de redistribuição dos recursos destinados ao Ensino Fundamental. A participação da EJA no FUNDEF foi vetada e esta medida afetou diretamente todos aqueles que, por motivos diversos, não conseguiram acesso à escola ou nela permanecer na denominada "idade regular".

No ano de 1998, dando continuidade ao processo de discussões que vinha ocorrendo, deu-se inicio às plenárias e aos debates sobre a Base Curricular Paritária ${ }^{11}$, envolvendo representantes de toda a equipe pedagógica das Unidades Escolares, das Unidades Regionais de Educação - UREs ${ }^{12}$ e da, então, equipe de Ensino Noturno da SME, que perduraram por todo o ano, sem que culminasse com a implantação da proposta por falta de recursos financeiros.

Em 1999, tendo em vista o processo empreendido no ano anterior foi implantada uma proposta para o Ensino Fundamental ( $1^{\mathrm{a}}$ a $4^{\mathrm{a}}$ série), que apresentava uma organização alternativa para o cumprimento da carga horária prevista na LDB. Ainda em 1999, as discussões sobre a Base Paritária foram retomadas e, em 2000, foi possível implantá-la. Foi regulamentada por meio da Resolução-CME nº 024 de 11 de dezembro de 2000.

Em 2001, instituiu-se, como parte integrante do Departamento Pedagógico, a Divisão de Ensino Fundamental Noturno, posteriormente redefinida como Divisão de Educação Fundamental de Adolescentes, Jovens e Adultos - DEF-AJA, numa caracterização dos sujeitos do processo educativo e das defesas empreendidas em prol da inclusão da EJA na categoria de modalidade do Ensino Fundamental 13. Em plenárias realizadas com professores do Projeto AJA e da EAJA de $1^{\mathrm{a}}$ à $4^{\mathrm{a}}$ série, a SME optou por reduzir as diferenças estabelecidas neste atendimento, definindo, na $1^{\text {a }}$ à $4^{\mathrm{a}}$ série, uma carga horária de $600 \mathrm{~h}$ presenciais e $200 \mathrm{~h}$ de atividades complementares, na tentativa de unificação aprovada pelo CME, na Resolução $n^{\circ} 037$ de 20 de março de 2002.. Essa opção viabilizou o financiamento para EAJA da RME, enquanto Ensino Fundamental.

Atentos à formação política e pedagógica de todos os envolvidos na EAJA, a SME tem participado ativamente dos movimentos nacionais que buscam discutir, interferir e propor

\footnotetext{
11 Na forma de organização denominada Base Curricular Paritária todas as áreas do conhecimento são contempladas com a mesma quantidade de horas-aula. Não existe relação de privilégio ou hierarquia entre os componentes curriculares sendo todas e cada uma delas entendidas como essenciais ao desenvolvimento cognitivo, motor, social, político, cultural e afetivo do educando.

12 Estrutura estabelecida na Rede Municipal de Ensino/RME em que 330 Instituições Educacionais estão subdivididas em cinco Unidades Regionais de Educação/UREs, que exercem um papel de coordenação e acompanhamento pedagógico às escolas.
}

13 Para mais detalhes acerca desta inclusão, ver Plano Municipal de Educação de Goiânia (2004) 
políticas para essa modalidade. Entre os referidos movimentos merecem destaque os Encontros Nacionais de Educação de Jovens e Adultos - ENEJAs e os Movimentos de Alfabetização - MOVAs. A SME participa desde o III ENEJA, ocorrido em 2001, bem como da organização do III Encontro de Alfabetização de Adultos - MOVA, ocorrido em Goiânia em agosto de 2003 com o tema "Mova como Política Pública".

Em 2002 é constituído o Fórum Goiano de EJA.A SME de Goiânia foi uma das articuladoras do processo, desde 1999. Esse movimento tem contribuído para o entendimento das especificidades da modalidade de EJA e para o seu fortalecimento, enquanto direito, na RME, uma vez que a SME viabiliza a participação de gestores, professores e educandos nos encontros promovidos por este movimento.

Com fundamentos nas discussões, estudos e realizações empreendidas desde 1992, foi iniciada em 2001, com a assessoria da faculdade de educação/UFG, uma pesquisa denominada "A construção de uma proposta democrático-popular de educação para adolescentes, jovens e adultos da Rede Municipal de Educação de Goiânia, pelos sujeitos do processo educativo". Dentre as 89 escolas, 40 aderiram ao processo de pesquisa intervencionista, cujo objetivo era a reorientação curricular da EAJA.

Durante os anos de 2001, 2002 e 2003 foram desenvolvidas reflexões e discussões sobre a prática pedagógica, com representantes de professores, educandos e, também, em várias situações, com o coletivo de profissionais administrativos das 40 escolas que aderiram à pesquisa. Os resultados prévios, obtidos em 2001, apontaram para uma unificação da EAJA de $1^{\mathrm{a}}$ à $8^{\mathrm{a}}$ série, cujo primeiro passo foi a adoção de elementos constituintes da Proposta do Projeto AJA: princípios, flexibilidade de freqüência; matrícula e avanço a qualquer momento do ano letivo; reuniões semanais de planejamento; avaliação processual e contínua, sendo descritiva para $1^{\mathrm{a}}$ à $4^{\mathrm{a}}$ série.

Também foram conquistas da pesquisa a garantia de formação continuada em horário de trabalho por meio de acréscimo de carga horária e um profissional no coletivo de professores, formação adequadas às especificidades da modalidade e a implantação do Projeto Estudar sem Fome, haja vista que o aluno da EAJA é um aluno trabalhador que, muitas vezes, vem direto do trabalho para a escola sem se alimentar.

A SME, preocupada em atender a uma demanda significativa de pessoas não alfabetizadas e incluí-las socialmente, criou, a partir do segundo semestre de 2001, o Projeto AJA-Expansão, com o objetivo de mobilizar e sensibilizar a população acima de 15 anos para o processo inicial de leitura e escrita. Esse Projeto, desenvolvido em parceria com 
movimentos sociais, empresas, igrejas e associações entre outros, realiza suas atividades em espaços alternativos com a participação de educadores populares em regime de voluntariado. Em 2003, a SME firma parceria com o Governo Federal, por meio do Programa Brasil Alfabetizado. O projeto passa a ser denominado "Programa AJA-Expansão/Brasil Alfabetizado."

Em 2003, com objetivo de conhecer melhor os educandos da EAJA, foi elaborado e proposto às Unidades Escolares, pela DEF-AJA em parceria com o Departamento de Adminsitração Educacional - DAE, um levantamento de dados referentes ao perfil por faixa etária, bem como às causas da evasão ou transferência desses. As análises dos dados apontaram, entre outros elementos, um índice significativo de educandos jovens na EAJA, com maior número na $5^{\mathrm{a}}$ a $8^{\mathrm{a}}$ série. A partir desse resultado foi possível a inserção da temática da juventude nas formações e discussões empreendidas pela DEF-AJA e Centro de Formação dos Profissionais da Educação "Paulo Freire" - CEFPE, com intuito de construir práticas pedagógicas que auxiliem no enfrentamento e na superação de situações limites relativas à juventude do cotidiano escolar.

Ainda em 2003, iniciou-se a estruturação de uma organização alternativa para o atendimento de 2 (duas) ou 3 (três) turmas de $5^{\mathrm{a}}$ à $8^{\mathrm{a}}$ série, em virtude de uma crescente demanda por atendimento a grupos com número reduzido de educandos, em diversas regiões da cidade. Essa Organização, aprovada pelo CME de Goiânia, por meio da Resolução n ${ }^{\circ} 103$ de 09 de junho de 2004, manteve a paridade entre as disciplinas.

Em 2002, 2003 e 2004, com o objetivo de divulgar, subsidiar e valorizar as práticas pedagógicas desenvolvidas nas Unidades Escolares, foi editada a revista EAJA Revelando nossa Lida, História e Arte, com produções de educandos educadores desta modalidade. Em 2004, primou-se pela continuidade do processo de pesquisa, estudos e debates, fundamentados em premissas freireanas e pela sedimentação e aprimoramento das conquistas realizadas nos anos anteriores, resultando numa única Proposta PolíticoPedagógica da EAJA encaminhada ao CME.

Durante o ano de 2005, os esforços se deram no sentido de divulgação, estudo e formação dos educadores, tendo em vista a efetivação dessa proposta nas salas de aula da EAJA. Essa proposta foi aprovada pela Resolução 140, de 22 de junho de 2005, do CME. Nesse mesmo ano, em 30 de novembro, foi prorrogada a Resolução 103 que garante a Organização Alternativa de $5^{\mathrm{a}}$ à $8^{\mathrm{a}}$ série.

Como forma de acompanhar e avaliar o desenvolvimento da Proposta Político- 
Pedagógica da EAJA, nos anos de 2006, 2007 e 2008, semestralmente, as escolas responderam instrumentos intitulados Dados Administrativo-Pedagógicos. Após sistematização, realizada pela DEF-AJA, os apoios das UREs devolveram os resultados na expectativa de provocar a ação-reflexão-ação no interior das mesmas.

Nos anos de 2007 e 2008 ações de grande significado foram desenvolvidas na EAJA. A primeira refere-se ao Projeto Revelando nossa História, com o objetivo de socializar experiências exitosas desenvolvidas na escola. Nos dois anos, foram premiadas 5 escolas e as noites de premiação se constituíram em momentos ímpares de formação, haja vista a participação, numa mesa redonda, de 5 sujeitos: um educando, um professor, um diretor, um funcionário administrativo e um coordenador pedagógico, além de um pesquisador de EJA, fazendo as considerações sobre as práticas explicitadas. A segunda ação diz respeito ao Projeto de implementação da leitura e escrita que, por meio dos Dados AdministrativoPedagógicos, das formações/discussões entre apoios, coordenadores pedagógicos e o coletivo escolar, intensificaram-se as ações relativas à leitura e escrita do educando.

Em 2008, a DEF-AJA retomou a avaliação da Proposta Política-Pedagógica e pediu sua prorrogação, junto ao CME. Ouviu dos apoios pedagógicos das UREs as contribuições para a sua reescrita e enviou uma carta, a cada professor da EAJA, na intenção de ouví-los em vários aspectos: planejamento com a presença de educandos na escola, concretização do trabalho coletivo e interdisciplinar na Base Paritária, participação de educandos no planejamento, registro da avaliação, atividades complementares e jantar na escola, dentre outros. A sistematização dessa carta, realizada pela DEF-AJA, foi devolvida às escolas por meio dos apoios pedagógicos das UREs.

Vale a pena destacar, também, como ação de avaliação para a reescrita da Proposta Polítcia-Pedagógica da EAJA em vigência, o GTE Ressignificando o trabalho pedagógico na $E A J A^{14}$ que, em 2008, além de discutir a proposta, ouviu os sujeitos dessa modalidade (professores, educandos e funcionários administrativos), em 16 escolas, sobre o significado da EAJA e contribuições da PPP para a prática pedagógica.

Em 2009, as UREs, o CEFPE, a DEF-AJA e as Unidades Escolares continuam os estudos e discussões com o intuito de reescrever a proposta. Também nesse processo, os apoios técnicos da DEF-AJA ouviram educandos de 8 turmas de Projeto AJA e apoios

14 Grupo de Trabalho e Estudos organizado, em 2008, pelo DEPE/CEFPE/DEF-AJA com o objetivo de discutir a PPP da EAJA. No ano de 2009, esse grupo recebeu novos participantes entre professores convidados, apoios da URE'S e da DEF-AJA para continuidade do processo e reescrita da proposta/EAJA. 
pedagógicos das UREs ouviram educandos de $1^{\mathrm{a}}$ a $4^{\mathrm{a}}$ série em 16 escolas, com o objetivo de perceber a sua avaliação em relação ao trabalho pedagógico desenvolvido, às expectativas de escolarização e à multisseriação, entre outros. Esses dados foram apresentados aos professores de $1^{\mathrm{a}}$ a $4^{\mathrm{a}}$ série e Projeto AJA num encontro onde puderam se manifestar sobre a reestruturação desses atendimentos. A sistematização de suas contribuições foram devolvidas em novo encontro.

Ainda há muito caminho a ser trilhado, e, nesse caminhar, vai-se explicitando o que se quer alcançar. São muitos os desafios postos às diversas esferas governamentais e movimentos comprometidos com a EAJA: ampliar os recursos financeiros destinados à EJA, tornando possível a universalização da Educação Básica; garantir mecanismos de mobilização/divulgação da modalidade em sistemas de comunicação, como forma de sensibilizar os sujeitos para o processo de escolarização; intensificar o processo permanente de acompanhamento às Unidades Escolares, subsidiando a prática pedagógica por meio da discussão e busca de efetivação da Proposta Política-Pedagógica da EAJA; ampliar o número de turmas formadas por educadores populares em parceria com entidades da sociedade civil, públicas e privadas; ampliar o atendimento nas turmas de EAJA, mesmo nos locais em que a demanda seja reduzida em relação àquela, convencionalmente encontrada e garantir a formação continuada nas escolas, bem como formação específica para professores que trabalham na EAJA, promovidas pelo CEFPE, entre outros.

O caminho percorrido pela EAJA na SME de Goiânia, desde 1992, demonstra, conforme FREIRE (2007.p.97), que não se pode entender os homens e as mulheres, a não ser (...) vivendo, histórica, cultural e socialmente existindo, como seres fazedores de seu "caminho" que, ao fazê-lo, se expõem ou se entregam ao "caminho" que estão fazendo e assim os refaz também”. Os educadores e educandos da EAJA, as equipes gestoras responsáveis por esta modalidade, a assessoria da UFG e demais movimentos comprometidos com a EJA vêm construindo a sua história em meio às contradições e conflitos inerentes a esta, avançando em alguns momentos, em outros enfrentando resistências para garantir as conquistas. No entanto, este caminhar da Rede demonstra a possibilidade de se garantir a continuidade de propostas e de construção coletiva, bem como efetivação de políticas públicas.

\section{2- Sujeitos da EAJA}


Quem são eles? Somente educandos e professores? Estes educandos, adolescentes, jovens, adultos ou idosos, são homens ou mulheres? São trabalhadores ou não? Estão empregados ou desempregados? Brancos, negros ou índios?Como se constituem?

Falar dos sujeitos da EAJA impele a pensar a totalidade destes educandos envolvidos no processo educativo dessa modalidade e, ao mesmo tempo, estabelecer as diferenças e pontos comuns entre eles. O pressuposto dessa compreensão é o próprio fazer educativo, cuja efetividade se dá não apenas na sala de aula ou na relação professor/aluno, mas em todos os movimentos que ocorrem na escola e na relação da escola com a comunidade.

A educação na EAJA é compreendida como um processo dialético e dialógico de formação humana, que abrange todos os aspectos da sua existência: o cognitivo, o politicocultural, o sócio-econômico e o afetivo; desenvolvidos na interação entre os diferentes sujeitos que compõe a instituição escolar. Nesse sentido, considera-se sujeitos da EAJA os educandos, os servidores administrativos, os professores, os coordenadores, os diretores e os apoios pedagógicos.

Quanto aos sujeitos educandos, uma de suas especificidades é pertencerem à classe trabalhadora e, ao mesmo tempo, serem trabalhadores, na grande maioria, do mercado informal, como mostra os Dados Administrativos e Pedagógicos de 2006, realizado nas escolas da EAJA. Os adultos e idosos, correspondem, conforme tabela abaixo a, aproximadamente ${ }^{15}, 45 \%$ e, normalmente são migrantes da zona rural, do interior do estado de Goiás, do Norte e Nordeste. São trabalhadores não qualificados, que vivem de trabalhos esporádicos, são donas de casa, avós, que cuidam dos seus netos ou que ainda trabalham de empregadas domésticas. São mães que não tem com quem deixar seus filhos para poder ir para escola, e que, por conta disso, leva-os com elas para a escola ou a abandonam quando não podem levá-los. As escolas, nos Dados Administrativo- Pedagógicos de 2006 e 2007, apontam que a maioria dos educandos exerce as profissões de empregadas domésticas, babás e diaristas, pedreiros, serventes, eletricistas e pintores, entre outras.

A tabela abaixo, sistematizada pela DEF-AJA, revela as idades predominantes na EAJA.

Tabela1- Faixa etária dos educandos da EAJA 


\begin{tabular}{|c|c|c|c|c|c|c|c|c|c|c|c|}
\hline \multirow[t]{2}{*}{ Ano } & \multicolumn{2}{|c|}{$\begin{array}{l}\text { Menores de } \\
14 \text { anos }\end{array}$} & \multicolumn{2}{|c|}{14 a 20 anos } & \multicolumn{2}{|c|}{$\begin{array}{l}\text { De } 21 \text { de } 25 \\
\text { anos }\end{array}$} & \multicolumn{2}{|c|}{$\begin{array}{l}\text { De } 26 \text { a } 60 \\
\text { anos }\end{array}$} & \multicolumn{2}{|c|}{$\begin{array}{l}\text { Maiores de } \\
60 \text { anos }\end{array}$} & \multirow[t]{2}{*}{ Total } \\
\hline & Qtde & $\%$ & Qtde & Perc.\% & Qtde & $\%$ & Qtde & $\%$ & Qtde & $\%$ & \\
\hline 2007(Agos.)* & 43 & 0,34 & 4611 & 36,81 & 1512 & 12,07 & 5933 & 47,36 & 428 & 3,42 & 12527 \\
\hline 2008 ( Set.) & 35 & 0,2 & 6816 & 38,25 & 2395 & 13,44 & 8029 & 45,06 & 545 & 3,06 & 17820 \\
\hline 2009( Abr.) & 30 & 0,21 & 5500 & 38,06 & 1642 & 11,36 & 6834 & 47,3 & 443 & 3,07 & 14449 \\
\hline
\end{tabular}

Fonte: DAE, movimento escolar.

*Esse movimento totaliza apenas educandos frequentes na EAJA da RME

Conforme Movimento Escolar do DAE de junho de 2009, no primeiro segmento $56,2 \%$ são mulheres e 43,8\% homens, normalmente, pessoas que não foram alfabetizadas ou tiveram passagem rápida pela escola quando jovens e, agora, ao voltarem, sonham com um futuro melhor e, portanto, desejam a continuidade escolar, para assegurar mais dignidade e cidadania. No segundo segmento 47,5\% são mulheres e 52,5\% são homens, na maioria, jovens e adolescentes, vinculados à cultura urbana, muitos deles oriundos do Cíclo ${ }^{16}$

Esses jovens e adolescentes possuem experiências recorrentes de descontinuidade escolar, exclusão social e conflito com a família. São pessoas em condição de desemprego ou subemprego, como apresentam os dados do "Perfil dos Sujeitos da EAJA de $4^{\mathrm{a}}$ e $8^{\mathrm{a}}$ Séries", levantados em 2008 quando da realização da avalição da aprendizagem nessas séries. $\mathrm{Na} 4^{\mathrm{a}}$ série, $35,7 \%$ dos educandos informaram que estavam desempregados e, na $8^{\mathrm{a}}$ série, 30,3\% deles disseram estar na mesma condição. Os mesmo dados revelaram ainda que, 37,3\% dos educandos da $4^{\mathrm{a}}$ série trabalham de 7 a 8 horas por dia e, 26,5\% trabalham mais de 8 horas ao dia. $\mathrm{Na} 8^{\mathrm{a}}$ série esses percentuais são de $32,1 \%$ e $28,4 \%$, respectivamente.

Os sujeitos educandos da EAJA são, na sua maioria, afrodescendentes, como revelam os dados do Perfil 2008: na $4^{\mathrm{a}}$ série, 64,8\% se autodefiniram como pardos e pretos. $\mathrm{Na} 8^{\mathrm{a}}$ série, $65 \%$ se reconheceram nas mesmas categorias. Os brancos representam $27,5 \%$ na $4^{\mathrm{a}}$ série e $24,4 \%$ na $8^{\mathrm{a}}$ série.

Na EAJA, existe um número significativo de educandos com Necessidades Educacionais Especiais/NEE, em decorrência das políticas de inclusão. Hoje, eles somam, segundo o Diagnóstico da EAJA, 214 educandos, representando 1,94\% dos 11.012 frequentes.

16 Pesquisa da Alto Permanencia, 2009 realizada pelo DAE e os apoios das UREs e sistematizada pela DEF-AJA. 
O número significativo de educandos com NEE nas salas de aula vem aprofundando as preocupações quanto à retenção e às dificuldades no processo de ensino e aprendizagem .

Esses sujeitos, possuem histórias semelhantes: histórias de exclusão, de falta de trabalho, de exploração no trabalho, de serem co-responsáveis pela sobrevivência familiar, de "voltar a estudar para crescer e ser feliz"17. Essa volta constitui-se em um desafio, para muitos educandos pois eles encontram dificuldades em se adaptar à cultura escolar, em cumprir uma rotina de ir todos os dias para a escola após o cansaço do trabalho e o enfrentamento das adversidades presente em suas vidas. Por conta desses, e outros fatores vinculados à própria escola, a evasão e a baixa frequência são desafios da EAJA, realidade que se configura em toda a EJA.

Como se apresentam os conflitos geracionais nesse universo? Os adolescentes sentem dificuldades em compreender os rítmos e costumes dos idosos, enquanto esses também não se adequam às irreverências e hábitos juvenis. Embora esses conflitos sejam concebidos, pelos educadores, como um dificultador do processso ensino-aprendizagem, Spósito (1996) afirma que a resistência aos conflitos entre as gerações enriqueçem a vida social, pois apontam novas alternativas e sinalizam possibilidades de mudanças.

No caso dos jovens, de acordo com Spósito (1996, p.101),

na maioria das vezes, as relações sociais mais significativas são gestadas fora da escola e da família, as tradicionais instituições socializadoras. [....] a rua aparece como espaço de formação dos grupos de amizade que podem se desdobrar nas galera, nas gangues, nos grupos de música e dança, como aqueles que se dedicam ao rock, ao RAP, entre outros.

Que experiências culturais a escola oferece no âmbito da sociabilidade juvenil? Que estratégias possibilitam ao idoso a convivência com seu pares? Como mediar a resistência e o conflito entre gerações de forma que enriqueçam a vida social e sinalizem novas alternativas, bem como possibilidades de mudanças?

Uma das ações que contribui nas relações entre jovens e adultos é a discussão sobre a importância do corpo na rotina escolar. Carrano (2008, p.162) afirma: "Uma atenção ao corpo pode contribuir para que os jovens dialoguem entre si e com as gerações adultas. É possível ajudar na construção de pontes para o outro, derrubando as portas dos "apartamentos" que nos deixam à parte da comunicação com o mundo". A escola pode ir além da visão técnica do trabalho corporal, e ser um espaço possibilitador da constituição do 
diálogo com o outro, no sentido de marcar a formação na sua essencialidade humana.

Conforme mencionado anteriormente, os adolescentes, jovens e adultos da EJA compõem, de forma relativa, um grupo homogêneo, comparado à população desse país. No entanto, a heterogeneidade também é comum para esses sujeitos. De acordo com Frochtengarten (2009, p. 31) "A diversidade de saberes, habilidades e ritmos de trabalho costuma ser a marca das turmas e representa um dos desafios ao trabalho pedagógico." A diversidade de saberes tem sido uma das dificuldades apontadas pelos educadores da EAJA.

Enfrentar esse problema é o desafio cotidiano. A organização curricular ainda tem desconsiderado os educandos e suas experiências aprendidas no mundo. A necessidade de dialogar com os saberes, os anseios e as expectativas dos adolescentes, jovens e adultos é premente, sobretudo na EAJA. Conforme analisa Oliveira e Paiva (2004, p. 104) "Isso quer dizer que dizer algo a alguém não provoca aprendizagem nem conhecimento, a menos que aquilo que foi dito possa entrar em conexão com os interesses, crenças, valores ou saberes daquele que escuta."

É também necessário perceber que a trajetória da aprendizagem é diferente para cada um desses educandos. Assim, é preciso romper com a visão linear da organização curricular presente nas escolas, que parte dos saberes mais simples para chegar aos complexos e buscar, cotidianamente, o significado atribuído pelos sujeitos ao que se deve aprender.

Quanto aos sujeitos educadores, considera-se que as escolas possuem coletivos que buscam atender às especificidades desses educandos e que carregam anseios e características as mais diversas possíveis. Os gestores e coordenadores demonstram-se compromissados com a modalidade, no entanto, nem todos conseguem envolver os profissionais, e nem garantem uma participação democrática, de fato, tanto de educadores quanto de educandos.

Em pesquisa realizada pelos professores do GTE Ressignificando 2008, percebeuse que os funcionários administrativos, em sua maioria, apresentam conhecimentos dos educandos: sobre as suas realidades, a importância da "volta aos estudos" para eles, sobre os critérios de flexibilidade da PPP da EAJA em relação aos mesmos, sobre situações peculiares de cada um. No entanto, muitos do s entrevistados ainda reclamam de uma certa segregação entre eles e o corpo docente, o que prejudica, de certo modo, um atendimento mais completo desses educandos.Eles conhecem as suas histórias, conversam e os aconselham, constroem vínculos que poderiam ser importantes para o desenvolvimento de um trabalho coletivo na escola. 
Mesmo percebendo essa tensão na relação entre os diversos trabalhadores da educação, considera-se que os funcionários administrativos, são, de fato, sujeitos da EAJA, pois desenvolvem um trabalho significativo nas escolas: o preparo dos alimentos, efetivando o Projeto Estudar Sem Fome ${ }^{18}$, o registro dos documentos, a parceria no desenvolvimento de atividades em ambientes diversificados e a higienização da escola, são atividades que não apenas subsidiam o processo de ensino e aprendizagem, mas também podem ser consideradas educativas pelo modo como esses profissionais se relacionam com os educandos.

Importante registrar um desafio a ser enfrentado pela EAJA, que refere-se à formação dos funcionários administrativos e gestores. Ela deve ser pensada com a expectativa de compreender os princípios e concepção dessa proposta e assegurar, para esses sujeitos, a participação e condições de interferir e contribuir no processo de formação dos educandos.

Em 2003, foi aprovado o Plano de Carreira dos Servidores Administrativos, que passaram para o quadro de Funcionários Administrativos da Educação- FAE. Esse plano não apenas estimula os profissionais no exercício as suas funções, como dá oportunidade de crescimento tanto pela formação inicial como pela formação continuada. Em 2008, foi aprovado o Plano de Carreira dos Servidores Municipais da Prefeitura de Goiânia, que inclui os novos concursados da Educação. É bom lembrar que ele representa uma conquista dos servidores municipais.

Todos os educadores da EAJA são profissionais concursados e licenciados, como define a Constituição Federal de 1988 e a LDBEN 9394/96. Muitos deles são especilaistas, mestres e doutores. Possuem o Plano de Carreira e Remuneração dos Servidores do Magisterios Público do Municipios de Goiânia, aprovovado pela Lei no 7997, de 20 de junho de 2000, como resultado das lutas e mobilizações da categoria, travadas na decada de $1990^{19}$.

Os educadores do Programa AJA-Expansão são pessoas da comunidade, que tenham, no mínimo, formação em ensino médio concluída. É um grupo bastante heterogêneo, alguns são aposentados, outros são funcionarios públicos, voluntários da comunidade, desempregados e estudantes de graduação que querem adquirir experiência em educação popular, entre outras características. A orientação pedagógica é garantida na formações inicial

18 O Projeto Estudar Sem Fome foi criado no Departamento de Alimentação Escolar (DAE) e no Fundo Municipal de Manutenção e Desenvolvimento do Ensino (FMMDE), a partir de reivindicações dos educandos em pesquisa ocorrido em 2001-2004, já citada anteriormente. Constitui- se em um jantar todas as noites. 19 GOIÂNIA: Estatuto e Plano de Carreira dos Servidores do Magistério Público do Município de Goiânia, 2000. 
de 40 horas, no mínimo, e a formação continuada, semanalmente.

O quadro de professores configura-se da seguinte forma:

Tabela 2 - Número de Profissionais da RME

\begin{tabular}{|c|c|c|c|c|c|c|c|}
\hline \multirow[t]{2}{*}{ Modalidade } & \multirow{2}{*}{$\begin{array}{l}\text { Programa } \\
\text { AJA- } \\
\text { Expansão }\end{array}$} & \multicolumn{2}{|c|}{ Projeto AJA } & \multicolumn{2}{|c|}{$1^{\mathrm{a}}$ à $4^{\mathrm{a}}$} & \multirow{2}{*}{$5^{\mathrm{a}}$ à $8^{\mathrm{a}}$} & \multirow{2}{*}{ Total } \\
\hline & & Regente & Ed.Física & Regente & Ed. Física & & \\
\hline Homens & 2 & 1 & 3 & 7 & 27 & 203 & 241 \\
\hline Mulheres & 45 & 30 & 5 & 175 & 25 & 394 & 629 \\
\hline Total & 47 & 31 & 8 & 182 & 52 & 597 & 870 \\
\hline
\end{tabular}

Fonte: Departamento de Gestão de Pessoal, setembro de 2009.

Os educadores da EAJA, assim como os educandos, chegam à escola cansados, pois, em sua maioria, fazem jornada dupla ou tripla de trabalho. Santos (2007), em pesquisa realizada com professores que atuam no segundo segmento da EAJA, afirma que a opção dos professores para esta modalidade tem como principal motivo a questão financeira, trabalham no terceiro turno para complementar o salário obtido com o trabalho diurno.

Um desafio posto à RME é a necessidade de romper com a rotatividade dos professores que atuam nesta modalidade. Discute-se muito a rotatividade dos alunos, mas pouco se fala na rotatividade do professor. Este elemento implica diretamente no processo ensino-aprendizagem. Tanto os educadores quanto os educandos têm, como desafio, a luta pela concretização de seus direitos. A reflexão sobre a condição de trabalhador em que educadores e educandos se encontram pode contribuir para a formação de ambos.

Embora atuem com uma carga horária excessiva e não tenha sido contemplada, na sua formação inicial, a questão da EJA, muitos educadores comprometidos com o fazer pedagógico, têm construído caminhos que mobilizam e mantêm o educando na escola, garantindo a este, aprendizagem com qualidade social.

A SME tem procurado dar visibilidade a estes trabalhos por meio de projeto, entre os quais, o "Revelando Nossa História", a revista "Revelando Nossa Lida, História e Arte", documentários produzidos por professores e alunos, no Fest Cine entre outras.

No que tange ao compromisso político-pedagógico dos professores, na argumentação de Freire (2001, p.49): "pareça fundamental que todo trabalhador do ensino,(...) assuma a natureza política de sua prática. Defina-se politicamente. Faça a sua opção e procure ser coerente com ela." Essa afirmação está relacionada a outra reflexão, a saber, a formação dos educadores. Embora esteja reservado um espaço somente para discussão da formação nesta proposta, é preciso registrar que o caráter da formação deve concentrar esforços para 
que o professor da EAJA explicite, em seu fazer pedagógico, seu compromisso com a construção de uma sociedade mais justa.

Por outro lado, que o educador "tenha competência técnica e científica capaz de gerar autoridade e, com efeito, a disciplina intelectual dos educandos. ${ }^{20}$. Esta não representa uma tarefa fácil pois, ao mesmo tempo, os educandos devem ser respeitados, enquanto sujeitos que trazem consigo saberes apreendidos e construídos nas relações estabelecidas, nos mais diversos ambientes por eles frequentados.

É importante perceber que todos esses aspectos, e outros mais, contribuem para a representação que o educando faz da escola e para a construção da sua própria identidade de estudante. Além dos fatores sociais, os motivos da evasão estão intimamente ligados à relação que estabelecem com a escola. Sendo assim, é importante observar, sempre: quem é esse "outro" que se apresenta como educando? Como se narram as identidades de gênero, raça, sexualidade, classe social, idade, profissão?

A heterogeneidade de sujeitos presentes na EAJA implica num constante repensar nas formas de atendimento, para manter o compromisso de garantir escolarização aos adolescentes, jovens e adultos que se encontram fora da escola e, que ainda não perceberam a necessidade da escolarização.

De acordo com Moreira e Candau (2007, p. 42) "Julgamos que cabe à escola, por meio de suas atividades pedagógicas, mostrar ao aluno que as coisas não são inevitáveis e que tudo que passa por natural precisa ser questionado e pode, conseqüentemente, ser modificado." Assim, é também papel da escola cultivar a compreensão de cada um, como sujeito histórico, bem como a responsabilidade de questionar, tensionar e desafiar a ordem social vigente.

\section{3- Bases legais}

A configuração flexível e inovadora da Proposta Político- Pedagógica da EAJA no município de Goiânia, justifica-se em vários fatores tais como as características e as condições sócio-históricas dos sujeitos educandos, o contexto histórico contemporâneo em que sobressai a globalização, o desenvolvimento tecnológico e as mudanças de paradigmas teóricos e culturais. Justifica-se também na legislação como a constituição Federal e a LDB no

20 Diálogo de componentes do GTE Ressignificando o trabalho pedagógico na EAJA na discussão do livro Pedagogia da Autonomia, em 2009. 
9394/96. A Constituição Federal de 1988, em seu Art. 208, diz que "O dever do Estado com a educação será efetivado mediante a garantia de: I- ensino fundamental obrigatório e gratuito, assegurada, sua oferta gratuita para todos os que a ele não tiveram acesso na idade própria; [...] VI- oferta de ensino noturno regular, adequado às condições do educando."

Assim, estabeleceu-se uma organização que procura, conforme determinado pela Lei 9394/96, de Diretrizes e Bases da Educação Nacional, valorizar as especificidades dos educandos possibilitando-lhes o direito de acesso ao sistema de ensino e sua permanência nele por meio um trabalho coletivo, visando contribuir para a construção de uma sociedade mais justa e igualitária.

A referida Lei, define as Diretrizes e Bases da Educação Nacional e aponta a necessidade de ofertar oportunidades de escolarização para jovens e adultos em diferentes artigos:

Art. $2^{\circ}$ A educação [...] tem por finalidade o pleno desenvolvimento do da cidadania e sua qualificação para o trabalho. educando, seu preparo para o exercício [...]

Art. $4^{\circ}$ O Dever do Estado com a educação escolar pública será efetivado mediante garantia de:

I - ensino fundamental, obrigatório e gratuito, inclusive para os que a ele não tiveram acesso na idade própria;

[...]

VI - oferta de ensino noturno regular, adequado às condições do educando;

VII - oferta de educação escolar regular para jovens e adultos, com características e modalidades adequadas às suas necessidades e disponibilidades, garantindo-se aos que foram trabalhadores as condições de acesso e permanência na escola;

[...]

Art. $5^{\circ} \mathrm{O}$ acesso ao ensino fundamental é direito público subjetivo [...]

$\S 1^{\circ}$. Compete aos Estados e Municípios, em regime de colaboração, e com assistência da União:

I - recensear a população em idade escolar para o ensino fundamental, e os jovens e adultos que a ele não tiveram acesso; $[\ldots]$

$\$ 5^{\circ}$. Para garantir o cumprimento da obrigatoriedade de ensino, o Poder Público criará formas alternativas de acesso aos diferentes níveis de ensino, independentemente da escolarização anterior.

[...]

Art. 10 Os Estados incumbir-se-ão de:

[...]

II - definir, com os Municípios, formas de colaboração na oferta do ensino fundamental, as quais devem assegurar a distribuição proporcional das responsabilidades, de acordo com a população a ser atendida e os recursos financeiros disponíveis em cada uma dessas esferas do Poder Público; 
[...]

Art. 32 O ensino fundamental [...]

$\S 4^{\circ}$. O ensino fundamental será presencial, sendo o ensino à distância utilizado como complementação da aprendizagem ou em situações emergenciais.

[...]

Art. 34 A jornada escolar no ensino fundamental incluirá pelo menos quatro horas de trabalho efetivo em sala de aula, sendo progressivamente ampliado o período de permanência na escola.

$\S 1^{\circ}$. São ressalvados os casos de ensino noturno e das formas alternativas de organização autorizadas nesta Lei.

No que se refere à legislação municipal, o Plano Municipal de Educação, Lei $n^{\circ}$ 8262, de 30 de junho de 2004, encontra-se em vigor e traz no item 2.2.2 - Educação Fundamental de Adolescentes, Jovens e Adultos, um diagnóstico com base nos dados do último censo demográfico (IBGE, 2000), bem como as diretrizes com os registros dos desafios a serem enfrentados por toda sociedade civil e, por último, os objetivos e as metas a serem alcançadas para resguardar o direito à educação dos adolescentes, jovens e adultos do município de Goiânia.

$\mathrm{O}$ atendimento ao Adolescentes, Jovens e Adultos, no ensino fundamental, não deve ficar restrito à função reparadora ${ }^{21} \mathrm{e}$, sim, estender-se para toda a vida, numa perspectiva de formação permanente e continuada (função qualificadora), seja em regime formal, como o ensino profissional e superior, seja em regime não-formal como cursos de atualização profissional. Segundo a Conferência Internacional sobre Educação de Adultos Declaração de Hamburgo (1997²2, Tema II, há de se viabilizar a eliminação de [...] barreiras entre educação formal e não-formal [...] estando atentos a que os jovens adultos tenham a possibilidade de prosseguir nos seus estudos depois de sua escolaridade formal inicial

A Educação de Adolescentes, Jovens e Adultos tem especificidades que requerem um atendimento diferenciado: garantir-lhes o acesso à educação fundamental em horário compatível com as condições do educando trabalhador, carga horária e currículo voltados à sua realidade, bem como flexibilidade de frequência, de matrícula e de avanço a qualquer momento do ano letivo, com o objetivo de possibilitá-los a realizar a sua formação escolar de

21 Segundo Cury (BRASIL: 2000, p. 6), “a função reapradora da EJA, limite, significa não só a entrada no circuíto dos direitos civis pela restauração de um direito negado: o direito a uma escola de qualidade, mas também o reconhecimento daquela igualdade ontológica de toda e qualquer ser humano."

22 Conferência Internacional de Educação de Adultos, do Francês " Conférence Internationale de Éducation des Adultes," por isso a sigla CONFINTEA. Convocada e coordenada pela organização das Nações Unidas para a Educação, a Ciência e a Cultura ( UNESCO). Esse encontro intergovernamental tem como objetivo possibilitar o diálogo e a avaliação das políticas de educação e aprendizagens de jovens e adultos na esfera internacional. 
acordo com suas condições e conhecimentos já adquiridos.

\section{2-Organização curricular}

A EAJA na RME de Goiânia adota um referencial teórico elaborado por autores variados para sua estruturação e orientação para das práticas desenvolvidas, a saber: Paulo Freire (1979, 1997, 2004) Vera Maria Candau (2007), Antônio Flávio Barbosa (2007), Vygotsky (1989), Marta Kohl (1989), Vitor Paro (1999), Inês Barbosa de Oliveira e Jane Paiva (2004). A leitura desses autores apresenta como pressupostos básicos a consideração do ser humano como sujeito historicamente constituído, a compreensão da realidade como processo que se configura em face da intervenção desses sujeitos, e os espaços de escolarização como locus que podem contribuir na formação humana dos sujeitos que deles participam.

Esta proposta incorpora a concepção freireana de que "a educação é uma forma de intervenção no mundo.” (2004, p. 98) Nessa ótica, a educação pensada torna-se significativa na medida em que propõe uma análise crítica da realidade e da sua transformação. Conforme aponta Freire (1979), a educação se afirma como espaço de construção do conhecimento e de cultura, em que os homens são sujeitos desse processo.

Considerando a relevância histórico- política das ações e do pensamento de Paulo Freire na Educação de Jovens e Adultos, tomou-se ainda, como contribuição, discussões elaboradas pela abordagem sócio- interacionista23 acerca da formação dos sujeitos e de seus mecanismos psicológicos, tendo-a como processual e tecida nas relações sociais por eles estabelecidas.

As concepções de currículo, conhecimento, trabalho e cultura, que embora sejam elementos indissociáveis, aqui se encontram abordadas, de forma específica, com o objetivo de explicitar os princípios que asseguram a visão de educação a ser desenvolvida na EAJA.

O currículo é aqui entendido como processo pelo qual o homem adquire, assimila, constrói e reconstrói conhecimentos, em um tipo particular de experiência proporcionada pela

23 Conforme "A formação Social da Mente" (1989), os estudos de Vygotsky, nas décadas de 1924 e 1925 , apresenta uma crítica a compreensão das funções superiores humanas. Assim ele propõe uma nova psicologia, baseada no método e nos princípios do materialismo dialético. O aspecto cognitivo é

compreendido a partir da descrição e explicação das funções psicológicas superiores, as quais, na sua visão, eram determinadas histórica e culturalmente. 
prática pedagógica, refletida e intencional dos educadores e educandos sobre o mundo para transformá-lo. O currículo é constituído como um caminho, um conjunto de princípios, os quais apontam vivências, convivências, ações, inter-relações que expressam significados confrontando saberes e conhecimentos, populares e científicos, num diálogo permanente. De acordo com Freire (2008, p.69):

toda prática educativa demanda a existência de sujeitos, um que, ensinando, aprende, outro que, aprendendo, ensina, daí o seu cunho gnosiológico; a existência de objetos, conteúdos a serem ensinados e aprendidos; envolve o uso de métodos, de técnicas, de materiais; implica, em função de seu caráter diretivo, objetivo, sonhos, utopias, ideais.

Dessa forma, o currículo escolar está assentada na reflexão sobre por que se ensina um determinado conteúdo em detrimento de outro, numa relação dialógica enquanto condição metodológica e de resgate pela escola dos saberes populares, articulando-os aos saberes científicos, na busca de desvelar a realidade e construir um novo conhecimento. Conforme argumenta Moreira e Candau (2008, p. 21),

o potencial que o currículo possui de tornar as pessoas capazes de compreender o papel que devem ter na mudança de seus contextos imediatos e da sociedade em

geral, bem como de ajudá-lo a adquirir os conhecimentos e as habilidades necessárias para que isso aconteça.

Concebe-se, então, o currículo como as várias experiências escolares envolvidas no processo do conhecimento em que homens e mulheres se sintam sujeitos críticos e capazes de interferir na sociedade em que vivem.

A Proposta Política- Pedagógica da EAJA tem como princípio concepções de conhecimento, linguagem, aprendizagem e trabalho coletivo, que visam garantir uma prática educativa democrática, dialógica e participativa para os sujeitos da EAJA.

O conhecimento é um processo humano, histórico, incessante, de busca de compreensão, de organização, formação de conceitos, de transformação do mundo vivido e sempre provisório. Tal ação humana está atrelada ao desejo de saber, de aprender e de mudança, porque o homem é um ser incompleto em busca do ser mais, ou seja, da sua humanização.

De acordo com Moreira e Candau (2008), o conhecimento é o elemento básico do currículo e o processo de aprendizagem deste conhecimento deve ser constituído na 
expectativa da compreensão das temáticas socialmente construídas afim de serem questionadas e reconstruídas pelos sujeitos envolvidos no processo.

A teoria dialética do conhecimento pressupõe, pois, a construção recíproca entre o sujeito e o objeto, pois é pela práxis humana sobre o mundo que, tanto o mundo como o homem se modificam e se movimentam construindo a história. A isso chamamos de prática social.

A ação educativa deve considerar que a realidade construída pelos homens, e na qual se inserem, é a fonte do conhecimento e deve estar a serviço de uma ação transformadora. Assim é que a EAJA fez opção por uma proposta político-pedagógica que toma como referência os princípios da Educação Popular $^{24}$, os quais possibilitam ao educador, na prática cotidiana, construir o currículo numa relação dialógica entre a realidade local e o contexto mais amplo. Na argumentação de Paulo Freire (1994, p.106),

é preciso porém, deixar claro que, em coerência com a posição dialética em que me ponho, em que percebo as relações mundo-consciência-práticateoria-leitura-do-mundo-leitura-da-palavra-contexto-texto, a leitura do mundo não pode ser a leitura dos acadêmicos imposta às classes populares. Nem tampouco pode tal leitura reduzir-se a um exercício complacente dos educadores ou educadoras em que, como prova de respeito à cultura popular, silenciem em face do "saber de experiência feito" e a ele se adaptem.

Nessa relação é necessário analisar que o compromisso com a educação também passa pelo esforço do estudo e da pesquisa, em que tanto o educador como o educando necessitam enfrentar esse desafio. Conforme argumenta Freire (2008, p.29), “é uma exigência que os momentos do ciclo gnosiológico vão pondo à curiosidade que, tornando-se mais e mais metodicamente rigorosa, transita da ingenuidade para o que venho chamando 'curiosidade epistemológica"”. A necessidade de a escola centrar-se na pesquisa, consiste em uma dedicação na busca, questionamento e constituição do conhecimento.

A linguagem é aqui entendida como um processo de interação e comunicação entre o indivíduo e o meio ou entre dois ou mais indivíduos. Representa o principal elemento do sistema simbólico dos grupos humanos,considerada um avanço na evolução da espécie, pois é por meio dela que o homem adquire formas de lidar com objetos do mundo exterior.

24 Conforme argumenta Trindade (2009, p. 31) "Escolas que, partindo das experiências das classes populares, resgatam e enriquecem o conhecimento clássico estudando a realidade atual, penetrando nela, vivendo nela. Escolas que (...) buscam desenvolver o valor social do trabalho, relacionando ciência e trabalho, consciência e experiência, e a cultura da cooperação e organização coletiva, vinculando responsabilidades individuais ao compromisso com o agrupamento comunitário." 
É formada por um aspecto verbal e outro não verbal; o primeiro podendo ser escrito ou falado e o segundo, desde a linguagem corporal até a simbólica, todos eles sendo fortemente influenciados pela cultura, pela ideologia sócio- político e econômica do meio em que se inserem. A compreensão dos fatores que interferem na organização do meio social possibilita que o indivíduo assuma uma postura crítica diante desse meio, além de permitir-lhe a apropriação e a construção de uma linguagem mais adequada à expressão de suas idéias, como participante do processo de transformação de si e de sua realidade.

Assim, as aprendizagens ocorridas pelas trocas que se estabelecem, na relação com o outro, pela mediação da linguagem, sendo significativas, além de favorecerem a aquisição de instrumentos e signos, podem conduzir ao desenvolvimento, à reflexão e à ação transformadora da realidade. Nesse processo o sujeito se apropria dos instrumentos materiais e simbólicos (culturais), que são utilizados para mediar sua relação com o mundo, com os objetos de conhecimento e de atuação, criando, a partir das relações estabelecidas com o meio, em diferentes contextos, sentidos pessoais, diferenciando-se enquanto ser humanizado, portador de um 'eu' mais autônomo.

Portanto, o uso da linguagem é determinado pela natureza sócio- interacional, uma vez que quem a usa considera as pessoas envolvidas no processo de interação, atuando no mundo social em um determinado momento e espaço. Assim, é na interação cultura/linguagem que a relação pensamento e palavra se concretizam num movimento vivo. Relação esta que não é estática, se dá ao longo do processo histórico de aprendizagem e, portanto, modifica-se permanentemente.

No processo de aquisição e desenvolvimento da linguagem, Vygotsky (1998) esclarece que ela é, inicialmente, signo social externo e vai, aos poucos, pela reelaborarão do sujeito, entrecruzando com os saberes que possui, tornando-se internalizada, sendo apropriada pelo sujeito. Nesse sentido, a Linguagem cujas funções de comunicação, síntese, generalização, planejamento, dentre outras, enquanto instrumento de mediação no processo de desenvolvimento do sujeito tem, na palavra, [...] "a expressão mais direta da natureza histórica da consciência humana, ou seja, a consciência se reflete na palavra como o sol em uma gota de água” Vygotsky (2001, p.486).

A visão de Paulo Freire (1996, p.54) converge com a de Vygotsky: "A conscientização é exigência humana, é um dos caminhos para a posta em prática da curiosidade epistemológica. Em lugar de estranha, a conscientização é natural ao ser que, inacabado, se sabe inacabado." Desse modo, a palavra não pode ser desprovida de significado, 
pois reflete o papel central da formação da consciência, tornando-se essencial ao processo de ensino e aprendizagem, com vistas à apropriação e construção dos conceitos.

A aprendizagem ocorre na construção conjunta do conhecimento, sendo educadores e educando os seus sujeitos, tendo como ponto de partida os saberes e as necessidades sociais do educando e como referencial a mediação pelo educador possibilitando-lhe a ampliação do conhecimento crítico da realidade, acesso ao conhecimento mais elaborado e a construção de um novo. Nas palavras de Freire (2007, p. 120) "a relação do conhecimento não termina no objeto, ou seja, a relação não é exclusiva de um sujeito cognoscente com o objeto cognoscível. Se prolonga a outro sujeito, tornando-se, no fundo, uma relação sujeito- objeto- sujeito."

O aprendizado ocorre por meio da significação do conhecimento pelo sujeito, o qual é possível pela relação dialética, bem como pelo confronto entre saberes e conhecimentos populares e científicos, em um diálogo permanente, não pela mera exposição de informações.

A busca da aprendizagem deve perseguir os questionamentos.Estes devem promover reflexões individuais e coletivas, tornando significativo o processo de conhecer. Conforme expressa o documento Brasil (2006, p. 47) "perguntas são instrumentos indispensáveis para produzir conhecimento. As pessoas aprendem quando precisam encontrar respostas para suas perguntas". Dessa forma, a aprendizagem ocorre quando se cria, no cotidiano escolar, situações pedagógicas em que os conteúdos trabalhados se apresentem para os educandos como uma necessidade.

A aprendizagem vista pelo campo da construção psicológica e da maturação do indivíduo está relacionada às funções psicológicas superiores ${ }^{25}$, conforme denomina Vygotsky. Em sua opinião, pensar a aprendizagem e sua relação com o desenvolvimento humano é percebê-la como possibilidade de desenvolvimento mental, em suas palavras (1991, p. 101):

o aprendizado adequadamente organizado resulta em

25 Importante registrar que para Vygotsky (1991), a complexa estrutura humana é constituída do processo de desenvolvimento presente nas relações entre o histórico individual e o social. Em suas palavras"“...] Quando se examina o processo de formação em toda a sua complexidade, este surge como um movimento do pensamento, dentro da pirâmide de conceitos, constantemente oscilando entre duas direções, do particular para o geral e do geral para o particular.”(1987,p.70). Assim, são consideradas funções psicológicas superiores: controle consciente do comportamento, atenção e lembrança voluntária, memorização ativa, pensamento abstrato, raciocínio dedutivo, capacidade de planejamento. 
desenvolvimento mental e põe em movimento vários processos de desenvolvimento que, de outra forma, seriam impossíveis de acontecer. Assim, o aprendizado é um aspecto necessário e universal do processo de desenvolvimento das funções psicológicas culturalmente organizadas e especificamente humanas.

Pensar na aprendizagem dos sujeitos da EAJA implica, portanto, compreender a cultura como elemento mediador desse processo. Esta concepção de aprendizagem coloca a necessidade de um constante repensar das práticas educativas como forma de enfrentamento dos "problemas de aprendizagem" bem como da construção de experiências inovadoras no campo da aprendizagem de adolescentes, jovens e adultos.

O trabalho coletivo na escola começa pela construção coletiva do projeto político-pedagógico e pressupõe a integração, a fluidez e o compromisso entre os que o planejam e desenvolvem as ações planejadas. Entende-se por planejamento escolar coletivo a efetiva participação de todos os integrantes dessa comunidade escolar na decisão dos rumos que nortearão as atividades escolares e extra-escolares. Segundo Veiga (2004), a construção coletiva do projeto político-pedagógico da escola, e as suas diversas fases do desenvolvimento, efetiva-se com base em alguns princípios fundamentais - como o da igualdade, da qualidade, da gestão democrática, da liberdade, da valorização do magistério sem os quais o trabalho coletivo torna-se inviável.

A organização coletiva das atividades escolares, segundo Veiga (2004), exige que os seus atores e autores tenham uma definição clara das finalidades da escola e, com efeito, do tipo de cidadão e de sociedade que pretendem formar.

A gestão democrática, condição necessária para a realização do trabalho coletivo, demanda dos educadores uma reflexão aprofundada sobre os problemas do contexto social e da vivência dos educandos e sua articulação com as teorias, que possibilite uma interpretação critica e dialética da realidade em questão. A gestão democrática e o princípio da liberdade, garantidos constitucionalmente, possibilitam

o repensar da estrutura de poder da escola, tendo em vista sua socialização. A socialização do poder propicia a prática da participação coletiva, que atenua o individualismo; da reciprocidade que elimina a exploração; da solidariedade que supera a opressão; da autonomia que anula a dependência de órgãos intermediário que elaboram políticas educacionais das quais a escola é mera executora (VEIGA, 2004, p. 19). 
Enfim, por desenvolvimento coletivo das atividades escolares entende-se o efetivo empenho de todos os integrantes da comunidade escolar na execução conjunta, responsável, objetiva e integrada do trabalho previamente planejado, de modo a garantir a qualidade do ensino e a própria formação permanente dos educadores envolvidos na construção pedagógica da escola.

$\mathrm{Na}$ tentativa de estruturar uma trajetória formativa que estimule de um lado, a superação do isolamento das disciplinas e de uma aprendizagem centrada numa visão de mundo fragmentada, e de outro, buscar, por meio de conhecimentos dos diversos componentes curriculares, alternativas de aprendizagem mais próximas da experiência imediata dos adolescentes, jovens e adultos, propõe-se os seguintes eixos norteadores:

A identidade fundamenta-se na compreensão de formação humana em que o sujeito se constitui na relação com o outro e com o mundo. Desse modo, a identidade não é definida como algo dado a priori, mas como metamorfose, um processo em que os sujeitos são históricos e dialeticamente autores de sua própria identidade, a partir da relação com outros sujeitos no convívio social. Conduz a respostas que revelam histórias de vida, trajetória profissional, papéis que se desenvolvem ao longo da vida, e revela também a dinâmica de mudanças da identidade de uma pessoa e suas interfaces: identidade profissional, sexual, enfim, identidade dos papéis que se desenvolve na sociedade.

Na EAJA a preocupação com a questão da identidade deve considerar, além do recorte de classe como elemento comum e demarcador desses sujeitos as diferenças geracionais e, ao mesmo tempo, as diferentes identidades constitutivas de um mesmo sujeito, seja ele idoso, adulto, jovem ou adolescente.

Carrano (2008, p.111), ao discutir a construção identitária da juventude, fala da importância de se conceber a questão da identidade pessoal e coletiva como um processo de interação e conflito. Ele considera que os jovens, na atualidade, têm certa liberdade de "selecionar as diferenças as com as quais querem ser reconhecidos socialmente. Isso faz com que a identidade seja muito mais uma escolha do que uma imposição.”

No entanto, a escola não tem atentado como uma instituição pouco favorável à criação de espaço de sociabilidade, de solidariedade, de debates públicos, capazes de possibilitar a formação de identidades com base em experiências e práticas coletivas de participação e convivência.

Segundo Spósito (1996) e Canclini (1999) a identidade é um conceito autoreferido e, ao mesmo tempo, narrado pela representação social. A identidade da juventude, por 
exemplo, tende a ser reconhecida a partir de estereótipos quase sempre produzidos pela mídia, sem fazer o recorte de classe e compreender a sua constituição histórica. Esta generalização remete a uma representação ou identidade coletiva de juventude como consumista e alienada. Ao contrário, quando se faz o recorte de classe é para qualificar a juventude /alunos da escola pública como violentos e marginais. Decorrem dessas construções duas situações bastante freqüentes: "o estereótipo é aliado intimo do preconceito, fato criador de enormes dificuldades para aqueles que se dedicam ao trabalho educativo" (SPÓSITO, 1996, p. 99). Não apenas os jovens, mas também os adultos da EAJA são identificados por estereótipos, os quais, na grande maioria das vezes, servem para justificar as dificuldades de aprendizagem dos mesmos.

Frochtengarten (2009, p. 135) considera os educandos adultos de EJA, como sujeitos portadores de identidades de fronteiras, uma vez que "ela está fundada sobre a comunidade com outros estudantes e, simultaneamente, sobre os contrastes com a cultura escolar. Portanto está edificada em terreno de fronteiras culturais." $\mathrm{O}$ autor afirma que esse terreno, a escola, gera abalos a todos os sujeitos que ali convivem, inclusive sobre os professores.

É na perspectiva de combater o preconceito social contra os jovens e adultos das classes populares, em situação de exclusão social, cultural e escolar, que a Proposta PolíticoPedagógica da EAJA, tem no conceito de identidade um eixo importante para a construção do conhecimento e a transformação da realidade, uma vez que ele permite desconstruir os mecanismos de construção e manutenção da exclusão dos educandos dessa modalidade.

Segundo Spósito (1996) a presença do Estado por meio de políticas para a juventude e para a população adulta, excluídos, é de fundamental importância para a formação de sua identidade coletiva e individual, bem como o papel da escola como espaço que possibilite a constituição de experiências culturais e de políticas participativas dos educandos. A ausência de projetos culturais e educativos portadores de significados de sociabilidade configura-se como crise da escola pelo seu esvaziamento de sentido produzido pelos alunos.

Assim, identidade individual ou coletiva, sempre pressupõe a dimensão da alteridade, ao ser uma categoria social e relacional. Ela se constrói a partir de experiências comuns, que se defrontam e confrontam entre si. Como afirma Paula Montero (1997), um dos elementos que faz evidenciar a questão da identidade situa-se nos grupos emergentes que passam a competir pela conquista de um mesmo espaço social. Mas é preciso, também, levar em 
conta esse movimento que constitui a identidade em sua dupla dimensão: trata-se de se perceber semelhante aos outros (ser reconhecido e reconhecer) e, ao mesmo tempo, afirmar a diferença enquanto indivíduo ou grupo. Essa diferença, paradoxalmente, só pode ser afirmada e vivida como tal, ao supor uma certa igualdade e uma certa reciprocidade (SPÓSITO, 1996, p. 99).

O princípio da identidade no currículo da EAJA tem o papel, de possibilitar aos sujeitos a reflexão sobre sua trajetória, os condicionantes históricos, as rupturas e reconstrução na formação da sua subjetividade e as suas condições de existência. Espera-se que o educando da EAJA se compreenda como sujeito produzido nas relações de força impulsionadas pela contradição entre capital e trabalho, e, com efeito, pela exploração do trabalhador pelo capitalismo. O entendimento das condições objetivas de exclusão é fundamental para a ressignificação da sua auto-imagem e para sua motivação às práticas de resistência a realidade social imposta.

A cidadania é concebida como igualdade política, econômica, jurídica e sóciocultural. É compreendida como processo de construção social, forjado no interior das práticas sociais e políticas dos movimentos populares. Implica, assim, na conquista do direito de atendimento de todas as necessidades básicas da pessoa humana e supõe o processo dialético de construção da sua identidade, bem como a compreensão de seu papel como ser social.

Segundo Pinsky (2003), o conceito de cidadania não é uma definição estanque, é construído historicamente, o que significa que seu sentido varia no tempo e no espaço. Há uma diferença muito grande em ser cidadão no Brasil, nos Estados Unidos da América, na Suíça ou na Etiópia. Tem-se em cada nação diferenças de regras que definem quem é ou não titular da cidadania. Em cada país o estatuto da cidadania vai se modificando, normalmente, se ampliando, como por exemplo, a inclusão da mulher, da criança e do adolescente, como cidadãos, do analfabeto, dos imigrantes e das demais minorias.

As lutas da sociedade ocidental em geral, em prol da cidadania, culminaram com a Declaração Universal dos Direitos Humanos pelas Nações Unidas em 1948, antecida pela Declaração dos Direitos do Homem e do Cidadão de 1789 na França e a Carta dos Direitos de 1791, nos Estados Unidos, segundo Pinsky (2003). As duas últimas declarações, romperam com o princípio de legitimidade que vigorava com base nos deveres dos súditos, e passaram a estruturar as relações sociais e a organização da sociedade a partir dos direitos do cidadão. A partir dessas duas declarações lutas foram travadas para se ampliar os direitos às minorias: à mulher, ao negro, à criança, ao índio, ao homossexual, ao idoso, ao trabalhador entre outros, de modo a definir que a expressão mais ampla da cidadania é o exercício concreto da 
democracia nas práticas cotidianas da sociedade e não apenas na expressão política da representação.

No Brasil, a cidadania ampla, estendida a todos os indivíduos, igualando os seus direitos, é um acontecimento histórico recente, reconhecida pela Constituição Federal de 1988. Como parte deste processo, cita-se a promulgação da Lei $n^{\circ} 8069 / 90$, Estatudo da Criança e Adolescente - ECA e o Estatuto do Idoso, Lei $n^{\circ}$ 10.741/2003, que distinguem esses sujeitos. Em relação à junventude, se desenvolvem, no Congresso Nacional, as discussões em torno da construção de um estatuto próprio, considerando as suas particularidades e necessecidades. Essa cidadania não foi outorgada, e sim conquistada, como diria Arroyo (2000), a partir dos processos de luta da sociedade civil organizada,

O trabalho enquanto categoria, assume ao longo da História, diferentes formas 26 de acordo com o modo de produção da sociedade. No capitalismo o trabalho adquire a forma de trabalho assalariado. Conforme Paro (1999.p.107) "sob o modo de produção capitalista, o trabalho deixa de ser móvel de realização humana para constituir-se em fonte de aniquilamento do ser humano como sujeito".

O trabalho é aqui tratado enquanto uma relação dialética entre sujeito e objeto (realidade primitiva), implicando modificação de ambos. É por meio do trabalho que o homem constrói historicamente a si e à sua existência material e transcende o âmbito da necessidade natural em direção à liberdade, compreendida como autonomia do ser em relação à natureza.

Costa (1996) aponta que o trabalho, então, é o que diferencia o homem como espécie e gênero dos outros animais. O processo-trabalho engendra uma relação dialética entre o homem e a natureza, pois ele a transforma, a humaniza e, ao mesmo tempo, transforma a si mesmo.

Neste início de século XXI27, vivenciam-se inúmeras mudanças no mundo do trabalho, onde as condições de vida do trabalhador estão cada vez mais degradadas. Os adolescentes, jovens e adultos da EAJA vivenciam estas mudanças pois, estão inseridos ou

26 Forma de escravidão, de servidão e de trabalho assalariado.

27 Conforme afirma Antunes in Costa (1999, p. 205), a classe trabalhadora, na passagem do século XX para o XXI, "é mais explorada, mais fragmentada, mais heterogênea, mais complexificada, também no que refere a sua atividade produtiva: é um operário ou uma operária trabalhando em média com quatro, com cinco, ou mais máquinas. Os trabalhadores são desprovidos de direito, seu trabalho é desprovido de sentido, em conformidade com o caráter destrutivo do capital, pelo qual relações metabólicas sob controle do capital, não só degradam a natureza, levando o mundo à beira da catástrofe ambiental, como também precarizam a força humana que trabalha, desempregando ou subempregando-a, além de intensificar os níveis de exploração." 
buscando se inserir neste mercado, uma vez que é por meio da sua força de trabalho que satisfazem suas necessidades básicas de sobrevivência, ocupando este, portanto, centralidade em suas vidas.

Estes educandos aprendem nas relações sociais tecidas no mundo do trabalho. Assim embora o trabalho na sociedade capitalista seja alienante, a educação enquanto práxis, ou seja, enquanto ação-reflexão- ação pode contribuir no sentido de instrumentalizar este sujeito para a compreensão, a crítica, a reflexão, o questionamento e para a busca de superação da realidade.

Não é papel de uma educação comprometida politicamente com a formação humana deste adolescente, jovem e adulto preparar para o mercado de trabalho. Mas, conforme Paulo Freire, não existe educação neutra, a prática pedagógica é política. Costa (2008), em pesquisa sobre o aluno trabalhador da EAJA, pontua que ao se pensar educação de jovens e adultos e o mundo do trabalho, deve-se considerar que, na atual conjuntura, as relações que se constituem entre a escolarização básica, podem possibilitar, ou não, a inserção, a permanência e também a mobilidade dos educandos no mundo do trabalho.

Em consonância com os princípios desta proposta, e com o definido pela LDB, sobre a necessidade de práticas pedagógicas articuladas à realidade concreta vivida por estes educandos, entende-se que a categoria trabalho deve ser um elemento fundante das nossas práticas pedagógicas. Conforme Silva (2004. p.127) “ é preciso que a escola traga a vida do trabalhador para dentro do seu cotidiano de práticas: que os conteúdos e metodologias sejam construídos e desenvolvidos a partir das experiências dos seus sujeitos."

Faz-se necessário que a escola reconheça e mantenha, "vínculos ou articuladores, ou se quisermos, princípios, que considerem a categoria trabalho como referencial para a concepção e organização do processo educativo" (Filho.2008.p.120). Entretanto, para que esta articulação aconteça o currículo escolar precisa levar em consideração os conhecimentos e as experiências dos sujeito bem como suas diversidades. Os conhecimentos trabalhados e apreendidos passam a contribuir de forma mais significativa para a formação humana dos educandos da EAJA.

$\mathrm{Na}$ discussão dessa organização curricular é preciso enfatizar a situação do educando da EAJA como um aluno trabalhador ou em vias de se inserir no mundo do trabalho. Possuem trajetória de vida marcada por relações estabelecidas no mundo do trabalho, muitos interromperam seus estudos, outros estão retornando para a escola devido as exigências deste mesmo mercado. Portanto, a categoria trabalho deve estar presente no 
cotidiano escolar da EAJA.

A cultura entendida como produto dialético do trabalho, é o mundo modificado pelo homem, que se descobre agente transformador da realidade. É um processo simultâneo de transformar-se e de transformar o mundo.

Pode-se afirmar que a cultura ocupa um lugar central em nossas escolas, uma vez que ela perpassa tudo o que acontece na vida social de todos que ali estão, bem como as representações que fazem destes acontecimentos. Os sujeitos trabalhadores da EAJA, (re)constroem sua realidade e a explicam a partir das diferentes formas de viver na qual estão inseridos.

Neste aspecto podemos dizer que a abordagem da diversidade e da pluralidade cultural é um importante elemento para ser utilizado nas práticas pedagógicas nas salas de aula da Eaja, ou seja, é um ponto de partida para o diálogo entre educadores e educandos.

Discussões sobre as relações entre trabalho, cultura e sociedade devem permear a prática pedagógica de todos os componentes curriculares. Moreira e Candau (2007, p. 45) chamam a atenção dos segmentos que compõem a escola e que pensam os currículos no seguinte aspecto:

A e escola está sendo chamada a lidar com a pluralidade de culturas, reconhecer os diferentes sujeitos socioculturais presentes em seu contexto, abrir espaços para a manifestação e valorização das diferenças. Tende a silenciá-las e neutralizá-las.(...) No entanto, abrir espaços para a diversidade, a diferença, e para o cruzamento de culturas constitui o grande desafio que está chamada a enfrentar.

Neste aspecto, faz-se necessário discutir sobre as relações de gênero, raça e etnia, sobre as diversas formas de produções artísticas e movimentos culturais. Em conformidade com a Lei 11.645/08 e com a realidade dos alunos da EAJA, ressaltamos a importância da valorização da identidade e da auto estima de educandos negros e indígenas.

Conforme Silva (2007), a utilização do termo gênero é recente, data de 1955, utilizado para dar conta dos aspectos sociais do sexo. O termo sexo designa os aspectos biológicos dos sexos masculino e feminino. Em oposição, “o termo gênero refere-se aos aspectos socialmente construídos do processo de identificação sexual” (SILVA, 2007, p. 91).

Este autor em referência as teorizações feministas afirma que, historicamente há uma repartição desigual dos bens materiais e simbólicos entre homens e mulheres. Essa distribuição desigual estende-se à educação e ao currículo, de modo a internalizar estereótipos 
e preconceitos de gêneros capazes de gerar nos professores expectativas diferenciadas para educandos e educandas. Essas expectativas direcionam, mesmo que inconscientemente, homens e mulheres a seguirem carreiras profissionais diferentes reproduzindo o acesso desigual ao poder.

Uma discussão crítica e dialética das categorias de gênero, raça e etnia na escola deve considerar as estreitas conexões entre conhecimento, identidade e esses conceitos, no sentido de identificar e desconstruir os mecanismos de reprodução da desigualdade social.É preciso buscar constante reflexão, abolindo preconceitos já cristalizaos e possibilitando ampliar as discussões da cultura de forma significativa.

Paulo Freire (1986), diz que cultura é a representação de experiências vividas, artefatos materiais e práticas forjadas dentro de relações desiguais e dialéticas que os diferentes grupos estabelecem em uma determinada sociedade, em um momento histórico particular. E ainda, cultura é uma forma de produção, cujos processos estão intimamente ligados com a estruturação de diferentes formações sociais, particularmente aquelas relacionadas com gênero, raça e classe. É, também, uma arena de luta e contradição, existindo culturas dominantes e dominadas, que expressam diferentes interesses e operam a partir de terrenos diferentes e desiguais.

Neste sentido, a proposta pedagógica da EAJA, comprometida com os sujeitos das classes populares que a freqüentam propõe que as salas de aula sejam um espaço de debate, questionamento e diálogo, bem como de desenvolvimento da auto- estima, do respeito, da aceitação e valorização da diversidade cultural.

Construir uma prática pedagógica democrática onde se consiga articular igualdade e diferença, numa perspectiva emancipatória, não é tarefa fácil, uma vez que esta não tem sido historicamente a prática das escolas.

Moreira e Candau (2007) ressaltam alguns elementos que consideram importantes de serem observados na formação dos educadores. A percepção da diversidade e pluralidade a partir de teorias e experiências em que os educadores possam se colocar em situação de análise de suas próprias reações. Possibilidade de reflexão de cada educador sobre sua própria identidade cultural, bem como sobre a formação cultural brasileira e abertura para os diferentes grupos culturais e étnicos.

\section{3- Metodologia}


A Proposta Político-Pedagógica da EAJA caracteriza-se pela intrínseca relação entre eixos, princípios, objetivos, organização curricular, metodologia e avaliação, numa perspectiva dialética, uma vez que as ações pedagógicas a serem implementadas e desenvolvidas no lócus da escola devem partir da avaliação diagnóstica e de uma metodologia que privilegia o trabalho coletivo e interdisciplinar na compreensão da realidade do educando das classes trabalhadoras e, com efeito, na seleção de conteúdos.

A SME entende que há diversas possibilidades metodológicas e que a escola tem autonomia na definição e na construção de suas metodologias, as quais devem ser coerentes com a proposta da EAJA.Devem-se fundamentar na LDBEN (BRASIL, 96), e na Constituição Federal (BRASIL, 1988), quando tratam da gestão democrática, da liberdade de aprender, ensinar, pesquisar e divulgar a cultura, o pensamento e o saber; da igualdade de condições de acesso, do pluralismo de idéias e da tolerância como princípios para uma educação de qualidade.

Para Freire (1987, p. 78), o diálogo não é palavra oca nem verbalismo, "é o encontro dos homens, mediatizados pelo mundo, para pronunciá-lo, não se esgotando na relação eu-tu." É por meio do diálogo franco, da palavra verdadeira, enquanto uma exigência existencial, que os homens ganham significação enquanto homens e, ao mesmo tempo, pronunciam o mundo e o transformam.

O diálogo, enquanto práxis e fazer pedagógico, pressupõem algumas condições fundamentais: um profundo amor pelo homem e pelo mundo, a existência de um campo para o exercício da liberdade, a humildade para aceitar o outro, a disposição para escuta do outro, a condição de ser livre em relação aos guetos, se reconhecer como um ser incompleto e em construção. O diálogo, na relação de ensino aprendizagem, começa na inquietação pela busca do conteúdo programático, na relação educador- educando problematizadores. Freire (2008, p.22 ) afirma: “[...] ensinar não é transferir conhecimento, mas criar as possibilidades para a sua produção ou a sua construção".

O desenvolvimento do currículo, na EAJA, deve partir do diálogo e se desenvolver mediado pelo diálogo, seja em tema gerador/eixo temático ou projetos de trabalho/ensino-aprendizagem, pois partem da realidade para a construção do conhecimento. De acordo com Vasconcelos (2000), estruturar o currículo partindo da problematização da realidade significa que o objeto do conhecimento tem grande afinidade com sujeito, pois os conteúdos em estudo surgem da análise do contexto de educandos e educadores.

As metodologias - tema gerador/eixo temático e projetos de trabalho/ensino- 
aprendizagem - apresentam coerência com a PPP da EAJA, pois elas, além de partir do princípio da dialogicidade, fundamentam-se na realidade, no interesse e necessidades do educando e os toma como sujeitos na construção do próprio conhecimento. Elas não apenas exigem como facilitam a realização do trabalho coletivo e interdisciplinar na escola.

O tema gerador, criado por Paulo Freire, emerge no final da década de 1950 e inicio de 1960, num contexto político democrático e do movimento de educação popular e educação de adultos. O trabalho pedagógico por meio do tema gerador, ancora-se na dialogicidade, na politicidade e na criticidade do ato educativo, na pesquisa e na prática interdisciplinar presentes na teoria freireana. Para Gouvêa (1996, apud RODRIGUES, 2003, p.1),

Todo tema gerador é um problema vivido pela comunidade, cuja superação não é por ela percebida. Ele envolve: apreensão da realidade, análise, organização e sistematização, originando programas de ensino a partir do diálogo. Portanto, é fundamental dialogar com os educandos para conhecer, objetivamente qual o nível de percepção da realidade, bem como a consciência de sua condição e visão de mundo, suas necessidades, desejos e aspirações. Geradores porque “(...) contém em si a possibilidade de desdobrar-se em outros tantos temas (eixos temáticos e subtemas) que, por sua vez, provocam novas tarefas que devem ser cumpridas" (FREIRE, 1987: 124).

Freire (1998) afirma que não propõe uma metodologia de ensino e sim uma teoria do conhecimento e um modo de aprender. Ele aponta como motor da sua teoria do conhecimento a curiosidade, a pesquisa, a criticidade de um lado, e o compromisso político de outro, em face dos (re) negados, dos proibidos de ler a palavra relendo o mundo. "O que eu tentei fazer e continuo hoje, foi ter uma compreensão que eu chamaria de crítica ou de dialética da prática educativa, dentro da qual, necessariamente, há uma certa metodologia, um certo método, que eu prefiro dizer que é método de conhecer e não um método de ensinar" (FREIRE, 1998, p. 38).

Rodrigues (2003) faz uma síntese descritiva das etapas de elaboração do tema gerador, como um meio didático de viabilizar o processo de ensino aprendizagem a partir do contexto de contradições e problemas vivenciados pelos educandos trabalhadores.

A primeira é o levantamento preliminar (diagnóstico) da realidade dos educandos procurando-se compreender como eles percebem e explicam os problemas que os cercam e como apontam soluções para os mesmos. Segundo Freire (1987, apud RODRIGUES, 2003, 1), “(...) investiga-se não os homens, como se fossem peças anatômicas, mas seu pensamento-linguagem referido à realidade, os níveis de sua percepção desta 
realidade, a sua visão do mundo em que se encontram envolvidos seus "temas geradores",28.

O segundo momento, de acordo com Rodrigues (2003), é a seleção das falas significativas dos educandos; aquelas que representem problemas e contradições na visão da comunidade e na perspectiva dos próprios educandos. Devem ser expressivas do pensamento da coletividade e não apenas de uma pessoa ou família. O grau de coletividade do problema é expresso pela quantidade de vezes que este é mencionado - quanto mais for recorrente, mais é significativo, mais incomoda e, portanto, está presente nas falas

A terceira etapa é a devolução à comunidade dos pré-temas, ação fundamental na teoria de Paulo Freire, devido ao seu caráter eminentemente político no tratamento didático-pedagógico, que se constitui em um movimento dialético e dialógico de observaçãoreflexão- ação. Essa premissa está presente na teoria de Freire em diferentes situações: entre educador e educando, entre educandos, educador e o objeto do conhecimento, entre natureza e cultura; sempre em busca de um humanismo nas relações entre homens e mulheres (FREIRE, 1987). Esse é o momento de confirmar se os pré-temas selecionados são significativos e necessários àquela comunidade.

O passo seguinte é a escolha do tema gerador e a construção do contratema. Rodrigues (2003, p.3),

aponta que eleito o tema gerador (que é a tese de partida), os professores analisam o problema/tema gerador e levantam as necessidades de saberes e conteúdos para verticalização, aprofundamento e superação do tema, objetivando desconstruí-lo ao longo e ao final do processo pedagógico. Ao fazê-lo os professores apontam, sob a sua visão, o objetivo final do processo, o ponto de chegada (antítese), que se constitui no contratema.

Assim constitui-se a rede temática: levantando o tema, o grupo de professores passa a desdobrar subtemas articulando os núcleos centrais dos conhecimentos/conceitos e conteúdos (os quais se fazem necessário dominar, para possibilitar a compreensão e análise da realidade local, micro, macro), estabelecendo uma seqüência programática entre si e dando uma visão geral do tema, denominada rede temática

28 Para realizar o levantamento, Rodrigues (2003, p.1 e 2) aponta a seguinte orientação:

Levantar os dados que a escola/professor(es) já possui(em): tanto em fichas de matrícula, como em atividades promovidas anteriormente e observações (aspecto qualitativo - falas e explicações - e quantitativo);

Elaborar instrumentos para ouvir os educandos: roteiro de entrevista, questões, observação, diferentes dinâmicas na escola envolvendo pais, alunos, funcionários;

Sistematizar os dados compondo um quadro síntese. Por ex.: dados qualitativos (falas); aspectos sócioculturais e da infra-estrutura local; dados quantitativos (quantas vezes a fala esteve presente) e situações significativas. 
A redução temática se faz após o trabalho coletivo, em que as áreas de conhecimento levantarão (dentre os saberes necessários para possibilitar a apreensão, análise e interpretação da realidade, para nela intervir) os conteúdos que cada uma trabalhará, negociando as interfaces - para não ficarem repetindo o que o outro trabalhou -, e possibilitando ampliações e ações interdisciplinares (RODRIGUES, 2003).

Planejamento e execução das aulas e atividades: apartir do tema gerador, rede temática, contra tema e questão geradora geral, os educadores, envolvidos no trabalho com os temas significativos para si e para os educandos, sendo criativos, planejam coletivamente suas aulas, dinamizando e enriquecendo as atividades, (re) organizadas de forma que os alunos tenham acesso aos conteúdos escolares (RODRIGUES, 2003).

Conforme Rodrigues (2003), trabalhar com temas geradores ${ }^{29}$ implica em um processo de formação permanente do educador, onde este se perceba como sujeito num movimento constante de aprendizagem.

A pedagogia de projetos não é uma invenção da atualidade, ela tem raízes históricas. Surge no contexto da emergência das ciências modernas e, em especial, do movimento da Escola Nova, como uma reação às práticas tradicionais de ensino, que tomam como centralidade do processo o educador, na perspectiva do que Freire (1987) chama de educação bancária. Segundo Oliveira (2006), Dewey e seu discípulo Kilpatrick foram os autores que mais impulsionaram a pedagogia de projetos a partir do conceito de experiência como fator central do processo de ensino e aprendizagem e da compreensão da educação escolar como um processo de vida e não preparação para a vida.

Esse novo paradigma educacional propõe desenvolver ações, junto aos educandos que ultrapassem as fronteiras da fragmentação do saber, transcendam o "conteudismo" conservador das práticas das salas de aula e propõe novos rumos pedagógicos inseridos em modelos epistemológicos que ressaltam a capacidade de criar, de construir e de se harmonizar com o universo (OLIVEIRA, 2006, p.4).

com os 'temas geradores', segundo Corazza (1992), o professor precisa: ser um 'leitor' crítico e rigoroso da realidade e do mundo para poder ajudar o aluno a dizer, ler e escrever sua 'PALAVRAMUNDO'; ir construindo a capacidade de teorizar sobre sua prática; possuir clareza acerca de suas concepções e opções fundamentais, tais como: projeto histórico, referencial teórico, princípios didático-metodológicos, do lado de 'quem' e do 'que' coloca sua práxis, sua utopia e seu sonho; estudar de forma a produzir uma sólida consistência conceitual; construir e criar conhecimentos; aprender, ao ensinar e indagar, ao responder; constituir e manter grupos de trabalho, estudo e discussão; 'fazer ciência' à moda de quem faz aventura; renunciar à menor parte do narcisismo de cada um, para que se estabeleça a pertença institucional"(p.48-55), pois concebemos a EJA como um processo de construção que tem a prática pedagógica do educador como produto do trabalho coletivo na interação com seus pares. 
Embora a metodologia de projeto fundamente-se na concepção liberal de educação, na perspectiva da Escola Nova, ela possibilita uma intervenção crítica na realidade e a construção interdisciplinar do conhecimento, se, de fato, partir de um problema concreto da realidade social e o educando (seus interesses e necessidades) for o centro do processo e participar de todas as etapas de construção do projeto, juntamente com o educador, como propõe Hernandez (1998) e Vasconcelos (2000), ao discutirem projeto de trabalho e projeto de ensino-aprendizagem, respectivamente.

Desse modo, o projeto não pode ficar restrito a datas comemorativas e eventos, nem pode ser uma construção realizada apenas pelos professores, mas baseia se na pesquisa e na ação conjunta, tendo como princípio a necessidade, o desejo e a participação do educando em todo o processo de sua elaboração (da escolha do tema ao relatório final e à avaliação) que, segundo Vasconcelos (2000), já é construção de conhecimento.

Hernandez (1998) apresenta como um dos maiores ganhos desse tipo de organização do trabalho escolar, o fato do projeto ser construído e desenvolvido pelos alunos com a mediação e coordenação dos professores, a partir de um tratamento interdisciplinar do ensino. O referido autor (p.53), afirma que a interdisciplinaridade vinculada a uma concepção de globalização do conhecimento, "parte do interesse do professorado de distintas matérias que se trabalhe em equipe e em tratar que os alunos descubram que os temas estão relacionados entre si." Desse modo, vai-se além das propostas individuais e amplia-se a intenção relacional, produzindo a convergência do grupo de docentes e discentes para estabelecer em conjunto um tema e as demais fases do trabalho pedagógico por meio de projetos.

Vasconcellos (2000) apresenta como possível roteiro de um projeto: a escolha do tema, os problemas a serem investigados, os objetivos a serem alcançados pelos alunos, os conteúdos que são construídos pela pesquisa e a teorização, na forma de produção de registro dos dados. A metodologia de trabalho é a própria forma de trabalho com projetos: os alunos devem articular-se na constituição de grupos de trabalho, planejamento do trabalho pelo grupo, atividade de campo, pesquisa e teorização, produção de registros, apresentação do produto final e a globalização, que é a busca de uma síntese geral sobre o tema-problema trabalhado. E, por fim, a avaliação geral do trabalho e a construção de indicadores para novos projetos.

Ressalta-se ainda que, a utilização dessas possibilidades de ação para o desenvolvimento do trabalho pedagógico na EAJA, não pode se desvincular do Projeto 
Político Pedagógico a ser gestado no "locus" da Unidade Educacional. É da articulação do PPP e do planejamento coletivo que as ações pedagógicas são desenvolvidas no interior da escola e tornam concretas um processo de ensino-aprendizagem crítico e transformador.

\section{4- Avaliação}

$\mathrm{Na}$ EAJA, a avaliação é constitutiva do próprio processo de ensino e aprendizagem. O processo de ensino/aprendizagem inicia-se pela avaliação diagnóstica realizada, coletivamente, pelos professores com o objetivo de apreender e registrar os níveis de aprendizagens de cada educando da escola, suas dificuldades iniciais, seus interesses temáticos, suas experiências e vivências culturais, com a leitura e a escrita e com os demais conceitos, objetos de conhecimento. Isso significa dizer que a avaliação não apenas valoriza o sujeito educando na sua individualidade e no seu tempo de aprendizagem e desenvolvimento, como também ela não é uma etapa posterior do trabalho pedagógico. A avaliação na EAJA é compreendida como um pressuposto fundamental para o desenvolvimento qualitativo do trabalho pedagógico na escola, pois é a partir dela que se definem os objetivos a serem atingidos, os conteúdos a serem trabalhados e a forma como trabalhá-los.

Ela é diagnóstica, processual, contínua e formativa ${ }^{30}$. Visa não a classificação dos educandos, sua exclusão e/ou punição, mas a tomada de consciência por parte do educador e do educando, em relação às aprendizagens realizadas, aos objetivos atingidos e à necessidade de um (re)planejamento coletivo do trabalho pedagógico. Sadler (apud Boas, 1998, p.185) diz que

\footnotetext{
A avaliação formativa diz respeito ao uso que se faz das informações sobre a qualidade do desempenho dos alunos com o propósito de apoiar sua aprendizagem (ou sobre a qualidade do trabalho escolar, com vista ao alcance de objetivos previstos).
}

A autora ressalta a importância da participação dos educandos nos processos avaliativos, tanto da sua própria aprendizagem quanto do trabalho desenvolvido pela escola como um todo. Educadores e educandos se apropriam e significam os resultados da avaliação formativa de modos diferentes. Para os professores essa avaliação é usada para tomar decisão

$30 \mathrm{Na}$ Educação Física a prática avaliativa exige diferentes ferramentas. Adota critérios que, ao final do processo devem ser retomados e dialogados observando como esse aluno consegue demonstrar a construção de conhecimentos que pode fazer e os avanços que obteve por meio da expressão corporal diversificada (oral, escrita, corporal-corporeidade e cultura corporal) A avaliação desse ser processual, contínua e articulada aos demais saberes da escola ( GORINI \& SOUZA, 2007). 
quanto à prontidão, à diagnose e à necessidade de reagrupamentos dos educandos para superação das dificuldades encontradas. Para os alunos serve para conhecer seu desempenho, com o objetivo de melhorá-los. Sadler (apud Boas, 1998) diz que os alunos trabalham para melhorar seu desempenho quando conhecem o que deles se espera, quando são capazes de comparar seu desempenho atual com o desejado e de se engajar em ações adequadas para reduzir essa distância.

Desse modo, ressalta-se a importância de ampliação das práticas avaliativas nas escolas que atuam com a EAJA. A efetivação do currículo escolar não se dá apenas na sala de aula e na relação aluno-professor e aluno-aluno, mas por meio da totalidade do trabalho escolar. O projeto político-pedagógico e os objetivos do processo educativo necessitam ser elaborados e avaliados pelo coletivo da escola como um referencial coerente na indicação do que avaliar na escolha e formulação dos instrumentos mais pertinentes à avaliação.

Essa compreensão comum dos objetivos, dos critérios de avaliação, do que avaliar e dos instrumentos de avaliação é fundamental para os processos de avanço e reclassificação dos educandos, coerente com o desenvolvimento e as aprendizagens previstas no processo educativo proposto pelo coletivo da escola, incluindo elementos que vão para além da simples aquisição de conteúdos, respeitando a individualidade e a heterogeneidade entre os educandos

Hoffmann (1998) fala do juízo de valor e da subjetividade do professor inerente ao processo avaliativo. Por conta disso ela parte da hipótese de que o sucesso e o fracasso das aprendizagens podem ser uma perigosa invenção da escola, que muitas vezes estabelece padrões mensuráveis e objetivos de aprendizagem incompatíveis com a realidade da comunidade escolar. Daí a importância da avaliação coletiva das atividades pedagógicas da escola, e não apenas dos educandos, no sentido de minimizar esse juízo de valor, que é efeito da sua visão objetiva e imparcial, puramente constatativa do fazer do aluno. O professor interpreta o que observa a partir de suas experiências de vida, dos seus sentimentos e do lugar teórico que ocupa.

É importante que o professor tome consciência da inevitabilidade do juizo de valor na avaliação para que ele possa conduzi-la num processo sistemático, no qual ele se implica juntamente com o avaliado. "Cada avaliador se denuncia ao avaliar pela releitura própria do que vê a partir de suas próprias concepções e do seu grau de saber sobre uma disciplina ou área de conhecimento" (HOFFMANN, 1998, p. 14). Assim, o professor ao definir uma resposta como completa ou incompleta, coerente ou incoerente, consistente ou inconsistente, 
"revela o próprio entendimento do assunto, a consistência ou profundidade com que o domina, a leitura que ele próprio faz do que está escrito ou de como está escrito. As respostas dos alunos são confrontadas com suas posturas e concepções teóricas e essas podem interferir no sentido do que lê ou observa" (HOFFMANN, 1998, p. 15).

A autora insiste na importância de se conceber a avaliação como um processo que se desenvolve na perspectiva da hipótese e não da certeza. "Hipóteses a serem continuamente confirmadas, negadas, reformuladas por um acompanhamento sério e permanente do professor em conjunto com outros professores, pais e outros educadores que se envolvam com os alunos" ((HOFFMANN, 1998, p. 17) e os próprios alunos.

É nessa perspectiva de uma avaliação permanente e formativa, em detrimento da avaliação classificatória e excludente, que a Proposta Pedagógica da EAJA, prevê a classificação e a reclassificação até o final do mês de março de cada ano, avanço a qualquer momento do ano, sem minimizar a formação do educando, e, ao mesmo tempo, realizando o diagnóstico periódico das aprendizagens e das dificuldades não sanadas, para o planejamento de outras atividades pedagógicas.

O avanço, a classificação e a reclassificação são práticas curriculares e inovadoras, desenvolvidas a partir da diversidade, da heterogeneidade e das condições históricas de existência dos sujeitos da educação de jovens e adultos. Essas experiências, na seriação, são regulamentadas na Lei de Diretrizes e Bases da Educação Nacional no 9394/96, nos artigos 22, 23 e 24, nas Resoluções 001/98 e 003/99 do Conselho Municipal de Goiânia, que reforçam estas possibilidades entendo-as como um dever do poder público e um direito do educando, que deve ser efetivado no contexto do processo avaliativo do mesmo.

\section{Orientações para a classificação, reclassificação e avanço}

A classificação se dá para aqueles educandos que, a partir da $2^{\mathrm{a}}$ série, são matriculados (em caráter especial) sem documentação anterior. Classificar é o processo de “enturmar" o educando na série que, de fato, poderá cursar, para efetivação da matrícula.

A Resolução/CME n 001/98, alínea “d”, define a classificação como “a avaliação do aluno-candidato pela Instituição de ensino de sua escolha, na série ou etapa anterior àquela por ele pretendida." Se ele entrar de janeiro a março, sem documentação, o coletivo de educadores, num processo de observação individual e de discussão, tanto entre eles como com o próprio educando, será responsável pela decisão sobre a série de ingresso do mesmo, que 
deve ser definida até 31 de março de cada ano. Se ele entrar após 31 de março, sem documentação, será matriculado em caráter especial, numa turma provisória estabelecida entre educando, coordenador/secretario, para ser classificado no final do ano.

A reclassificação visa regularizar a vida escolar do educando que demonstrar um desenvolvimento incompatível com aquele demonstrado na documentação apresentada. A Resolução - CME n 001/98, aliena “e”, define a reclassificação como "a avaliação do grau de conhecimento e de experiência do aluno feita pela escola a partir do seu rendimento escolar na série, ciclo ou curso, tendo como base as normas curriculares estabelecidas". O art. $3^{\circ}$ afirma que o educando poderá se submeter à reclassificação quando: seu rendimento escolar estiver em desacordo com o da série cursada por ele; quando o aluno não obtiver os $75 \%$ de frequiência para aprovação exigidos na LDBEN; quando ele for transferido de outra instituição de Ensino do país e do exterior. Lembra-se que não é aconselhável retroagi-lo da série indicada na documentação, uma vez que a legislação - LDBEN 9393/96 e as Resoluções nº 001/98 e nº 003/99 do Conselho Municipal da Educação, que normatizam essas práticas - não fazem referência a esse retorno ${ }^{31}$.

O avanço é, também, um procedimento pedagógico legítimo, portanto não exige, no final do ano letivo, qualquer outro procedimento para a regularização da vida escolar. Ele pode ser realizado a qualquer momento do ano mediante a constatação, pelo coletivo da escola, de que o educando demonstra desenvolvimento e experiência que o assegure na série seguinte. A avaliação deve ser efetiva e sistematicamente realizada, utilizando-se de diferentes instrumentos e reflexões sobre os seus resultados com a participação dos educandos e todos os profissionais envolvidos.

A baixa frequência do educando não deve ser considerada como um critério absoluto para a não realização do avanço, pois o mesmo pode não ter uma frequência regular, mas ser alguém que se envolve cotidianamente nas práticas sociais de leitura, escrita e interpretação do mundo, estando, portanto, apto a enfrentar maiores desafios de aprendizagem.

No entanto, a frequência é elemento fundamental para a formação do educando, uma vez que a escola se constitui como espaço de encontro entre educandos, educadores e conhecimento. É nela que se estabelecem vínculos de solidariedade, confiança, amizade, entre outros, valores fundamentais para a consolidação de uma sociedade mais igualitária. Daí a 
importância da decisão coletiva nos processos de análises para o avanço.

Em suma, o processo avaliativo deve ser organizado e sistematizado, de modo que educadores e educandos identifiquem o desenvolvimento das aprendizagens, as dificuldades, os motivos da não-aprendizagem e as possíveis intervenções para superação das mesmas.

\section{5 - Formação}

Amparados pela LDBEN 9394/96 que garante a "formação de profissionais da educação, de modo a atender aos objetivos dos diferentes níveis e modalidades de ensino e as características de cada fase do desenvolvimento do educando..." e em consonância com o art. $4{ }^{\circ}$ no inciso VII, assegura-se aos profissionais da EAJA receber formação continuada que o ampare a trabalhar com diferencial, preparando-se para interagir com os educandos através do exercício do diálogo ( Parecer CEB nº 11/2000 p. 58).

A formação continuada deve ser espaço constante de discussões, de envolvimento e comprometimento com novos saberes, garantindo alternativas metodológicas e possibilidades para reconhecimento de uma identidade profissional específica para os educadores da EAJA.Conforme pesquisa realizada em 2001-2004, (cf. Histórico) a formação é "essencial para o desenvolvimento de práticas e ações pedagógicas voltadas para a realidade e especificidade da educação de jovens e adultos", e deve ser caracterizada como trabalho. A tarefa educativa é uma atividade exercida pelo conjunto de pessoas de uma sociedade no seu cotidiano e "o professor é aquele que tem por profissão, ou seja, por função social específica e especializada, realizar parcela significativa da atividade educativa que a sociedade considera relevante para sua conservação e transformação" (Bussmann e Abbud, 2002, p.135).

Segundo Marcondes (2002) a apropriação crítica e a construção de conhecimento constituem objetivos de qualquer formação. A relação de dialogicidade, que compreende as condições sociais, políticas, econômicas, históricas e ambientais as quais determinam a realidade educacional, o entendimento da vida cotidiana da escola, dos saberes e fazeres da experiência docente e discente, considerando a dialética entre a teoria e a prática reflexiva como essencialidade para a ação pedagógica, devem nortear os trabalhos de formação.

Para Vygotsky (2001, p.462), o professor deve ter um elevado conhecimento do objeto e da técnica de sua área. Deve ter embasamento cultural vasto, pois o trabalho educativo e pedagógico deve estar implicado em transformar a educação em uma criação de vida: "a vida só se tornará criação quando libertar-se definitivamente das formas sociais que mutilam e deformam. Os problemas da educação serão resolvidos quando forem resolvidas as 
questões da vida."

Paulo Freire (1998, p.23) ao abordar os saberes da prática educativa argumenta: "quem ensina aprende ao ensinar e quem aprende ensina ao aprender". Assim a atividade de ensinar exige segurança, competência profissional e generosidade baseada na natureza relacional e dialógica da educação, com uma dimensão política, ética e estética.

A natureza da educação pauta-se na constituição da pessoa, na capacidade da atividade criadora e na formação que possui. Os conhecimentos epistemológicos são imprescindíveis para uma prática educativa satisfatória. A formação de professores para atuar na Educação de jovens e Adultos carece de políticas destinadas a esse fim, como nos adverte Santos (2007, p.14): ...”os caminhos se direcionam para a compreensão de que o público que essa educação atende é específico e exige um professor com formação específica."

É nesta perspectiva que a formação no interior da escola é de fundamental importância para que as especificidades existentes em cada unidade escolar seja objeto de estudos, avaliação e discussões realizadas a partir do envolvimento do coletivo da EAJA, no sentido não apenas de compreender as especificidades dos educandos como também de encontrar estratégias de ensino capazes de tocar o universo dos mesmos. A formação do professor, envolve situações de aprendizagem em que a reflexão da própria ação, a busca de informações, o reconhecimento do trabalho e as estratégias usadas sirvam de superação dos problemas que aparecem no decorrer da prática educativa.

Para Pinheiro (2008), o desenvolvimento desses momentos possibilita o diálogo entre os saberes diferenciados tendo como referência várias racionalidades, e a complementação e enriquecimento das relações. Proporciona uma atitude crítico reflexiva sobre a atuação profissional "mediante procedimentos de observação, investigação, sistematização e produção de conhecimento pedagógico, construção de propostas de intervenção e de avaliação" (MEC/SEF, apud Marcondes 2002, p.192). Esse autor afirma que a formação propicia uma investigação da prática pedagógica dos educadores, em que eles passam a questionar suas próprias posturas e verdades e também podem construir alternativas significativas para o processo ensino-aprendizagem no cotidiano da sala de aula.

Um dos aspectos da formação é o que relaciona a educação especial na perspectiva inclusiva, que tem com base o documento Política Nacional de Educação Especial na Perspectiva da Educação Inclusiva ${ }^{32}$, que apresenta a seguinte perspectiva de formação:

32 Documento elaborado pelo Grupo de Trabalho nomeado pela Portaria Ministerial no 555 , de 5 de junho 
Para atuar na educação especial, o professor deve ter como base da sua formação, inicial e continuada, conhecimentos gerais para o exercício da docência e conhecimentos específicos da área. Essa formação possibilita a sua atuação no atendimento educacional especializado,aprofunda o caráter interativo e interdisciplinar da atuação nas salas comuns do ensino regular, nas salas de recursos, nos centros de atendimento educacional especializado, nos núcleos de acessibilidade das instituições de educação superior, nas classes hospitalares e nos ambientes domiciliares, para a oferta dos serviços e recursos de educação especial.

Considera-se importante buscar a discussão das Tecnologias de Informação e Comunicação, visto que esta tem sido, no contexto atual, um meio de formação dos professores. Belloni (1998, p. 06) aponta essa necessidade quando nos diz: "Uma nova pedagogia já está sendo inventada que concebe tecnologias como meios, linguagens ou fundamentos das metodologias e técnicas de ensino, sem esquecer de considerá-las como objeto de estudo e reflexão, assegurando sua integração crítica e reflexiva aos processos educacionais."

A formação também envolve a nova infra-estrutura tecnológica disponível na sociedade das tecnologias, contemporaneidade, haja vista que contar com laboratórios de informática e não saber utilizar como ferramenta de trabalho exclui professores e educandos desta sociedade. Faz-se necessária a formação para o uso das Tecnologias de Informação e Comunicação (TICs), inserida à realidade onde o fazer pedagógico acontece.

Desta forma para a EAJA, é necessário uma formação que possa contribuir no desenvolvimento do trabalho pedagógico, na "busca de superar o caráter de suplência e na garantia como direito e modalidade da educação básica, da sua afirmação como modalidade educativa e como direito social, sobretudo no campo da formação", Machado (2008,p.161,171), considerando e respeitando o educando em todas as suas especificidades, como sujeitos trabalhadores e que trazem consigo uma bagagem diversa de saberes.

\section{6- Orientações}

$\mathrm{O}$ atendimento às necessidades, anseios e especificidades dos educandos da EAJA deve ser o foco da práxis pedagógica dessa modalidade. Nesse sentido, são apresentadas orientações que objetivam contribuir no desenvolvimento deste trabalho.

Os professores da EAJA, em sua maioria, trabalham, por turno, uma carga horária de 30 horas semanais, numa mesma escola, para cada contrato. Isso contribui para a melhoria 
da qualidade da educação, proporcionando momentos de estudo, planejamento e pesquisa, em horário letivo.

As aulas devem ser organizadas, prioritariamente, com a mesma duração, possibilitando uma melhor organização do trabalho administrativo-pedagógico. O horário das aulas, preferencialmente, é rotativo, para atender às especificidades do aluno trabalhador.

As atividades complementares devem ser contempladas no Projeto Político Pedagógico, realizadas de forma interdisciplinar e registradas em fichas específicas. A organização e execução das atividades complementares são de responsabilidade do coletivo de professores de cada Unidade Escolar, com o acompanhamento e orientações do coordenador pedagógico e/ou do diretor. A Divisão de Educação Fundamental de Adolescentes, Jovens e Adultos e na Unidade Regional de Educação contribuem com informações para o desenvolvimento das mesmas.

As horas presenciais se caracterizam por aulas formais e não formais, ocorridas dentro do horário normal de aula, seja dentro ou fora da escola, com a presença do educador e educando.Elas subsidiam o processo pedagógico, valorizando o histórico de vida do educando, garantindo-lhe seu desenvolvimento científico, artístico e cultural dentro da escola; possibilitando maior intercâmbio com a comunidade em seus diversos segmentos; desenvolvendo atividades que incentivem a pesquisa e a busca de conhecimento pelo próprio aluno.

O registro de uma síntese das atividades complementares é feito em campo próprio, nos diários e, detalhadamente, na ficha de registro das atividades pedagógicas complementares.

O planejamento individual semanal é um momento de estudo e pesquisa que ocorre na Unidade Escolar, em horário de trabalho, podendo também ser utilizado para participação em formação promovida pelo CEFPE conforme critérios estabelecidos nas diretrizes.

O Planejamento coletivo deverá acontecer nos dias estipulados no calendário escolar podendo também, acontecer no horário de aula, desde que os educandos não sejam dispensados, devendo ser contemplado na PPP e analisado e aprovado pelo Departamento Pedagógico/Unidade Regional de Educação.

É importante ressaltar que cada professor se responsabiliza igualmente pelas atividades desenvolvidas na escola, assim, coletivamente: participa do planejamento escolar e se inteira das atividades que são desenvolvidas durante a semana; contribui na efetivação das 
atividades previamente planejadas coletivamente.

\subsection{1- Primeiro Segmento}

Esta Proposta tem como objetivo contribuir para reflexões e discussões das aprendizagens dos educandos e ainda subsidiar as unidades escolares para a organização do trabalho pedagógico enfatizando a relação educador e educando. Conforme a Proposta de Orientação Curricular para o $1^{\circ}$ Segmento da EJA, MEC (1997, p. 14) “A elaboração de currículos baseadas nessas indicações, inevitavelmente genéricas, exigirá dos educadores o esforço de complementá-las com análises de seus contextos específicos, a partir dos quais poderão formular de modo mais preciso os objetivos de seus programas."

A concepção freireana de educação é pautada no respeito aos sujeitos. Neste contexto, as práticas pedagógicas devem partir da realidade do educando numa relação de diálogo sendo mediadas pelo vínculo que se estabelece entre educando, educador e conhecimento. A partir desta concepção adotada e considerando que essas discussões foram ampliadas no Brasil, principalmente no início da década de 80, com a abordagem históricocultural, ampliam-se as referências em relação ao processo de ensino-aprendizagem. Neste sentido, autores como Bakhtin (1988), Braggio (1992), Brandão (2001), Vygotsky (1998), Cagliare (2001), Soares (2001), Morais (2002), dentre outros, contribuem para fundamentar as orientações para o primeiro segmento.

A alfabetização de adultos, que se inicia antes e na $1^{\mathrm{a}}$ série, tem continuidade nas séries posteriores, compreende aspectos metodológicos no qual o sujeito participa, pensa, discute, dialoga com seus companheiros, interage, tem iniciativa e toma decisões. Sendo o diálogo, um importante instrumento que propicia o conhecimento e o reconhecimento do educando como sujeito do processo de ensino aprendizagem e de sua história.

O sujeito no processo de alfabetização $^{33}$ traz consigo saberes que foram construídos ao longo da vida. São experiências que devem ser valorizadas, pois são alicerçadas na sua luta pela sobrevivência e pelos seus direitos de cidadãos e cidadãs. Nesta perspectiva alfabetizar a partir do conhecimento que os educandos trazem é desafiador, propõe uma prática que tem como objetivo a leitura e escrita como função social. A prática da alfabetização na sala de aula deve se basear na construção coletiva de novos saberes,

33 Conforme SOARES ( 2001, p.44) “ Letramento é o estado ou condição de quem se envolve nas numerosas e variadas práticas sociais de leitura e de escrita”. Entende-se que a concepção de alfabetização e a produção do conhecimento assumida na proposta contempla as discussões sobre letramento. 
coadunando saber escolar e saber popular, tendo como essencialidade o processo dialógico, a oralidade, os conhecimentos já existentes, articulando aos saberes sistematizados nas várias áreas do conhecimento, numa perspectiva interdisciplinar e de busca de totalidades, Paulo Freire (1999, p. 29) sobre a organização do saber entre as classes populares, nos afirma:

Nossa cultura popular é de tradição oral. Essa memória social se conhece a si mesma desde uma estrutura oral. Nós intelectuais formamo-nos dentro de uma ruptura com essa tradição; sobretudo o intelectual latino-americano: somos faladores, mais telefonamos do que escrevemos cartas e, no entanto, nos rodeamos de livros e textos. E essa nossa cultura de ênfase gráfica (livresca) é, muitas vezes, superposição sobre a oralidade dos grupos populares. Quando a gente, intelectuais, se soma à oralidade cultural do povo é importante não esquecer que há diferentes modalidades do conhecimento $[\ldots]$

Considerando esta tradição oral e os saberes que os educandos trazem é fundamental trabalharmos desde a primeira série a partir de textos, pois é por meio deles que podemos possibilitar que os conhecimentos adquiridos ao longo da vida possam ser explicitados, sejam eles ligados ao cotidiano dos educandos e direcionados as suas construções a respeito da leitura e escrita advinda das exigências que a vida lhes imprimir, seja pelos contatos escolares ou não com a escrita produzida historicamente.

Alfabetizar a partir de textos significativos, gêneros textuais como: carta, poesia, contos entre outros fornece suporte para pensar o mundo e decifrar o sistema da escrita alfabética percebendo que os textos expressam idéias, sentimentos, opiniões que muitas vezes se relacionam com a vida dos sujeitos envolvidos no processo ensino e aprendizagem ampliando os conhecimentos que interferem na maneira de ver o mundo. É nesse contato que o educando vai fazendo descobertas, comparando, conhecendo e reconhecendo palavras e expressões, tendo como ponto de referência um texto significativo e não palavras isoladas. Bakhtin (1988, p.95) adverte:

$\mathrm{Na}$ realidade, não são palavras o que pronunciamos ou escutamos, mas verdades ou mentiras, coisas boas ou más, importantes ou triviais, agradáveis ou desagradáveis, etc. A palavra está sempre carregada de um conteúdo ou de um sentido ideológico ou vivencial. É assim que compreendemos as palavras e somente reagimos àquelas que despertam em nós ressonâncias ideológicas ou concernentes à vida.

A alfabetização deve acontecer em todo o percurso do ensino fundamental, para que possibilite aos alunos a continuidade nos estudos dominando as várias áreas do conhecimento. Segundo Freire e Macedo (1994), o analfabetismo é um problema social que se resolve por meio de mobilização social, portanto, a alfabetização não deve ser somente 
aquisição de habilidades, implica numa compreensão crítica da realidade onde os envolvidos participam da construção do conhecimento e da reconstrução de uma nova sociedade, produzindo leitores cidadãos.

O adulto, educando de EJA, vem de um processo de exclusão da escola, já perdeu muito tempo da vida escolar, tem pressa em aprender e prosseguir com os estudos trazem muitos conhecimentos. Segundo Marta Kohl (1999), a inserção do adulto em situações de aprendizagem vem carregada de diferentes habilidades e dificuldades (em relação à criança), trazendo consigo maior capacidade de reflexão e de conhecimento.

De acordo com Morais (2002), a linguagem oral e escrita, a análise lingüística e a prática de leitura são os princípios básicos do sistema alfabético, que nortearão a prática pedagógica no primeiro segmento, no qual os educadores buscam estratégias que possibilitem os educandos pensarem sobre como a língua se estrutura.

A prática educativa deve contribuir para que os educandos, na problematização da vida concreta adquiram novos conhecimentos e procedam com a superação das formas de saber cotidiano. Assim, o saber historicamente acumulado e os saberes cotidianos devem ser articulados em todos os componentes curriculares 34.

É necessário que a prática pedagógica seja interdisciplinar, pois os conhecimentos historicamente acumulados compõem a proposta curricular contemplando o ensino de Arte, Língua Portuguesa, História, Geografia, Matemática, Educação Física e Ciências e estes possibilitam a ampliação dos mesmos tornando o processo de ensinar e aprender mais significativo.

A Educação de Adolescentes, Jovens e Adultos da Rede Municipal de Goiânia, em conformidade com a LDBEN art. $37, \S 1^{\circ}$, em que assegura oportunidades educacionais apropriadas, e buscando atender as especificidades desta modalidade, se organiza, buscando garantir as funções da EJA conforme o Parecer CEB/CNE 11/200035, respondendo aos anseios dos educandos que foram excluídos da escola e buscam concluir seu estudo mais rápido36.

No inicio da escolarização, os educandos se encontram no processo inicial de

\footnotetext{
$34 \quad$ O trabalho com os componentes curriculares estão detalhados nas orientações.

35

O Parecer explicita três funções para EJA: a reparadora (devolve a escolarização não conseguida quando criança), a equalizadora (oferta maior) e a qualificadora (educação continuada).

36 Conforme escuta realizada com educandos de $1^{\mathrm{a}}$ à $4^{\mathrm{a}}$ série e Projeto AJA em 2009, para a Reescrita Coletiva desta PPP: 79,6\% dos educandos apresenta m expectativa de continuidade do processo de escolarização e desse percentual $43,6 \%$ querem chegar no curso superior.
} 
desvelar o sistema alfabético, entende a língua materna, compreende o valor da linguagem oral e escrita como meio de integração entre gerações. Alguns não codificam nem decodificam e não dominam os símbolos e operações matemáticas, outros efetuam cálculos mentais, mas não conseguem sistematizar em operações matemáticas. Faz-se necessário a promoção de diálogos e espaços de desenvolvimento tendo como foco a problematização da realidade integrada aos conhecimentos sistematizados. Produzem textos que não seguem os padrões convencionais, com marcas da oralidade, no nível alfabético e/ou alfabéticoortográfico. É fundamental que diariamente haja momentos de oralidade, leitura e escrita.

Os educandos em processo de alfabetização se manifestam oralmente e apresentam inicialmente leitura com dificuldade, já descobriram o sistema alfabético de escrita, necessitam de apropriar-se das convenções da nossa língua. Reconhece que não escrevemos como falamos e que um mesmo som pode ser grafado com mais de uma letra, percebem as irregularidades das relações letras-sons. Efetuam cálculos mentais e sistematizam como pensam; desenvolvem situações problemas embasados em questões cotidianas, transpondo-as para relatos escritos, aproximando o conhecimento adquirido ao conhecimento científico proposto.

O educador propiciará momentos em que o educando interaja com diversidade de textos, a telemídia, a opinião de outros e emita sua própria opinião sobre o tema em questão, de forma oral ou escrita, fazendo uso de histórias da tradição oral, relatos cotidianos de maneira que organize mentalmente, elaborando textos e transformando-os em escrita. Os educandos deverão ser capazes de ler com fluência, tendo se apropriado das irregularidades, sons e letras passíveis de construção de regras. Efetuam cálculos mentais e escritos identificando com conhecimentos científicos vistos e sua aplicabilidade nas questões cotidianas.

Os educandos em processo de alfabetização são capazes de ler e interpretar textos com fluência e significado, escrever com coerência, coesão e estrutura textual. Dominam os princípios básicos do sistema alfabético e consolidam as correspondências grafo - fônicas, morfológicas, fonéticas além das sintaxes, semânticas e pragmáticas. Busca e seleciona textos de acordo com suas necessidades e interesse, se expressa por escrito com eficiência e de forma adequada as diferentes situações comunicativas. Demonstra domínio de símbolos e operações matemáticas, resolve situações problemas que exigem mais cálculos e raciocínio lógico fazendo conexão dos conhecimentos e das áreas estudadas, deverão produzir textos narrativos, descritivos, dissertativos e outras estruturas textuais. 
Neste sentido, estas orientações consideram os sujeitos como produtores do conhecimento na perspectiva de elevar a auto-estima, fortalecer a confiança na sua capacidade de aprendizagem, valorizar a educação como meio de desenvolvimento pessoal e social. Para tanto os conhecimentos científicos, históricos, a produção literária e artística devem ser entendidos como patrimônios culturais da humanidade a qual devem ter acesso na perspectiva que a alfabetização é um processo ao longo da vida.

\title{
2.7.2- Componentes curriculares no primeiro e segundo segmento
}

\begin{abstract}
ARTE
A Arte em suas diferentes linguagens - artes visuais, música, dança e teatro, está presente no cotidiano de nossos educandos em diferentes contextos, seja através da diversão e do entretenimento, através da religiosidade, da educação, entre outros. A Arte mesmo sem ser percebida permeia e traz algum sentido aos nossos educandos da EAJA, sendo que estes trazem consigo uma bagagem sócio-cultural e a mesma deve ser respeitada e valorizada. Porém, o ensino de Arte pode e deve proporcionar a "ampliação das possibilidades de participação social e cultural de forma crítica, criadora e autônoma" (BRASIL, 2002, p.135)

De acordo com a proposta curricular do MEC para a Educação de Jovens e Adultos (2002), o ensino de Arte na EJA tem como principais objetivos: conhecer, experimentar e explorar as diferentes linguagens artísticas; compreender e utilizar a arte como linguagem; experimentar e conhecer materiais, instrumentos e procedimentos artísticos diversos em Arte; construir uma relação de auto confiança com a produção artística; identificar, relacionar e compreender a arte como fato histórico contextualizado nas diversas culturas, entre outros.

A arte deve garantir aos educandos uma ampliação do conhecimento de diferentes culturas e etnias, seja no âmbito regional, nacional ou global. Portanto, devem conhecer e compreender a pluralidade e a diversidade cultural incluindo, entre outros, o estudo sobre a história e a cultura afro - brasileiro e indígena previsto na Lei Federal $\mathrm{n}^{\mathrm{o}} .11 .645$, de dez de março de 2008 (BRASIL, 2008). Proporcionando assim, a valorização pela própria cultura e o respeito pelas demais que os circundam.

O ensino de Arte está alicerçado em três eixos de aprendizagem significativa. De acordo com Barbosa (1999): o fazer, o contextualizar e o apreciar. Cabe a cada educador em sua linguagem específica garantir esses três pilares essenciais para a construção do
\end{abstract}


conhecimento em Arte. As linguagens artísticas que compõem o ensino de Arte possuem seus campos específicos, com objetivos e propostas distintas, entretanto vivemos em um mundo complexo, onde as inter-relações devem ser estabelecidas para a formação integral dos educandos, sendo assim, a interdisciplinaridade deve se fazer presente dentro da formação escolar em Arte, como em qualquer outra área do conhecimento. Morin (2003), afirma que o desafio da complexidade também é um desafio da globalidade, portanto a interação e a contextualização se tornam atitudes essenciais para a formação do ser humano.

A presente proposta visa garantir a especificidade de cada linguagem artística: artes visuais, dança, música e teatro para os educandos da EAJA, visando contribuir para a elevação do senso crítico dos mesmos, a sua auto-estima e autoconfiança.

As Artes visuais estão presente desde os primórdios da vida humana e fazem parte do cotidiano de forma bastante significativa. Desde os mais simples objetos artesanais presentes no dia a dia dos educandos como nas mais valiosas e elaboradas obras artísticas. As linguagens visuais no mundo contemporâneo estão cada vez mais abrangentes, pois as novas tecnologias (computador, cinema, vídeos, cartazes e outros multimídias) convivem ainda com a vasta produção artesanal tão presente na nossa cultura popular.

O ensino das artes visuais na EAJA visa ampliar os meios de apreensão, de compreensão e representação do mundo desses alunos, alfabetizando-os na linguagem visual nas mais variadas formas de leitura de imagens.

A educação do olhar é objetivo essencial das artes visuais, preparando o educando para uma apreciação qualitativa do mundo, com a marca de sua subjetividade alimentada por códigos de qualidade artística e estética advindos tanto das tradições culturais como do novo em arte. O saber em artes é construído na integração entre a experimentação a apreciação e a informação contextualizada.

A dança como forma de arte, está engajada com o sentimento cognitivo e não somente com o sentimento afetivo ou o de liberar emoções (REID,1981). É por meio do corpo dançando, que os sentimentos cognitivos se integram aos processos mentais e que pode levar a compreensão do mundo de forma diferenciada, ou seja artística e estética, assim o corpo que dança e o corpo na dança torna-se fonte de conhecimento sistematizado e transformador (MARQUES, 2007).

Espera-se que o aluno da EAJA possa conhecer, perceber e trabalhar de forma artística e estética com o corpo, por meio da dança, estabelecendo novas formas de viver e de construir a sociedade. Assim, a dança traz para o aluno a possibilidade de interagir 
corporalmente com o mundo, de forma crítica e consciente. A dança trabalha seus conteúdos dentro do fazer artístico (improvisação e composição em dança), o apreciar estabelecendo relações de empatia, rejeição, ou aceitação entre o apreciador e o intérprete da dança e o contextualizar, ou seja, compreender a história do corpo em sociedade e a história da dança e suas construções artísticas no decorrer da história da humanidade.

A música é uma linguagem artística que está presente ativamente no cotidiano dos jovens e adultos. Em todos os convívios sociais de nossa sociedade a música se faz presente. Sendo assim, o jovem ou o adulto traz consigo uma bagagem musical, sendo esta na maioria dos casos, uma bagagem restrita. $\mathrm{O}$ ensino de música na EAJA tem como intuito proporcionar uma ampliação da bagagem cultural em música dos nossos educandos.

Espera-se que o ensino de música na EAJA permita que o educando possa ter contato com a criação Musical, que consiste em experimentar sons corporais, instrumentais, objetos sonoros, entre outros; com a apreciação Musical, ampliação do repertório musical dos educandos, seja em âmbito nacional e internacional, abrangendo diversas culturas e etnias; e com a contextualização: relacionar a música e os diversos sons com o contexto social no qual estão inseridos.

O ensino de música deverá ser contemplado em todos os níveis da educação básica de acordo com a Lei $n^{\circ}$ 11.769, de 2008 que estabelece que "a música deverá ser conteúdo obrigatório, mas não exclusivo, do componente curricular".

O teatro envolve a perspectiva do recriar a realidade em que o aluno está inserido com o intuito de poder transformá-la. Através do fazer e apresentar uma peça teatral os educandos poderão conhecer um pouco sobre essa arte, que não é muitas vezes acessível a todos, e discutir os temas relativos à sociedade que os circundam.

Espera-se que o teatro permita que os educandos possam ter contato com: o fazer teatral, que consiste na criação ou reelaboração de uma peça teatral; apreciação teatral, proporcionar aos educandos o contato diferentes textos da dramaturgia brasileira, promovendo através de visita ao teatro ou apreciação de vídeo o conhecimento de diferentes estilos e gêneros teatrais; contextualização: relacionar os conteúdos teatrais com temas como comportamento, atitudes, posturas, onde o aluno coloca-se como age e relaciona-se com o mundo.

\section{CIÊNCIAS}

O avanço cada vez maior da ciência e da tecnologia tem sido impulsionado pela 
grande produção de conhecimentos científicos, inovações tecnológicas e avanços dos meios de comunicação e informação. Essa realidade delega a escola um grande desafio: a construção de espaços para a difusão e apropriação da cultura científica.

Esta construção torna-se complexa na medida em que a dificuldade em compreender as questões específicas da ciência e tecnologia vai além da desinformação de alguns, estando também intrinsecamente relacionadas às diferenças culturais e sociais. Segundo, Macedo e Katzkowicz:

\footnotetext{
Continuar mantendo a maior parte da população como analfabetos científicos pressupõe um aspecto que só faz agravar os grandes traços de iniqüidade da região, inabilitando essa maioria de participar democraticamente na tomada de decisões sobre o uso dos progressos científicos na sociedade. (MACEDO e KATZKOWICZ, 2003, p. 67).
}

Diante deste desafio e das discussões que se têm estabelecido acerca de uma formação que considera o educando em sua singularidade, totalidade, e múltiplos contextos, torna-se necessário romper com a visão elitista do ensino de ciências que ao longo de décadas tem buscado atender às exigências mercadológicas. Neste contexto, sugere-se que o Ensino de Ciências na Educação de Adolescentes, Jovens e Adultos (EAJA) seja pautada numa educação científica como prática social a qual implica um currículo que incorpore práticas inovadoras e significativas.

Segundo Schnetzler (et al, 2000), deve-se haver um questionamento acerca das visões simplistas do processo pedagógico do ensino de Ciências que usualmente tem sido centrado no modelo de transmissão-recepção e na concepção empirista-positivista de Ciências. Diante desta realidade os professores de Ciências da EAJA devem tomar consciência da necessidade de planejar, avaliar e desenvolver atividades de ensino que contemplem a (re)construção dos saberes dos educandos.

Nesta perspectiva o professor desempenha um papel fundamental na (re)definição dos processos pedagógicos, a partir da problematização dos conteúdos, deixando de lado a mera reprodução e descrição do conhecimento historicamente construído. Para além disso, deve buscar promover, segundo as Diretrizes Curriculares Nacionais da Educação de Jovens e Adultos (BRASIL, 2002), a reflexão, a troca de idéias, o confronto de opiniões, a valorização das informações trazidas pelos educandos a partir de suas leituras de mundo, promovendo assim, um ensino significativo. Para que essas situações se concretizem na sala de aula, a seleção dos conteúdos e dos instrumentos que serão utilizados nesse processo de ensino- 
aprendizagem, devem visar a integração desse educando com a realidade social em que vive, rompendo com o ensino exclusivamente memorístico.

A escola deve oferecer um currículo relevante para os educandos com assuntos relacionados às questões ambientais, à visão de universo, à promoção da saúde e aos avanços científicos e tecnológicos. Perpassando estes assuntos, sugere-se ao professor discutir com os educandos as implicações éticas relativas aos avanços da ciência, demonstrando que esta não é neutra, está em constante (re)construção e não se constitui uma verdade absoluta.

Nesta perspectiva, consideramos importante que o professor assuma a postura de mediador do processo de ensino-aprendizagem. Orienta-se que este desenvolva um trabalho pedagógico que possibilite aos educandos, segundo as Diretrizes Curriculares Nacionais da Educação de Jovens e Adultos (BRASIL, 2002): entender a ciência como construção humana, portanto histórica e social, por meio da qual os conhecimentos científicos são construídos; perceber-se enquanto agente ativo com possibilidades a modificar a realidade em que vive; identificar as inter-relações entre ciência e tecnologia, seus riscos e benefícios; entender e valorizar as ações de promoção da saúde em seus diferentes aspectos, social, individual e ambiental; saber aplicar os conceitos científicos na resolução de problemas cotidianos; e valorizar o trabalho coletivo, com vistas a construção do conhecimento crítico.

Atualmente, há uma demanda cada vez maior sobre o papel que os professores devem exercer na construção da sociedade. Entretanto, não é difícil identificar situações em que faltam ações docentes que envolvam os educandos. Diante disso concordamos com Nóvoa (1999) que afirma ser o reforço de práticas pedagógicas inovadoras, construídas pelos professores a partir de uma reflexão sobre a experiência, a única saída possível para um trabalho docente de qualidade e significativo no ensino de Ciências.

\section{EDUCAÇÃO FÍSICA}

Inscrita na história da humanidade, talhada pelo tempo e pelas representações de cada época, a Educação Física carrega em si uma dimensão simbólica, constituída por conceitos e sentidos adequados à função social que ela exerce em cada período e contexto histórico.

Desde o homem primitivo e os movimentos naturais necessários à sua sobrevivência, passando pela história antiga, com o desenvolvimento das habilidades corporais para a guerra, tocando sempre na relação paradigmática entre corpo e espírito ou 
saúde e doença, tudo isso, inspirou transformações na Educação Física pelo mundo, durante a idade moderna e contemporânea.

No Brasil não foi diferente, desde os primeiros habitantes, os índios nativos, já havia a prática de atividades físicas de caráter funcional (correr, nadar, lançar, arco e flecha) e ritual através das danças homenageando os deuses, pode-se identificar, ainda, os primeiros jogos desenvolvidos nesta terra, a peteca e a corrida com troncos. De outro ponto, observamos as primeiras influências culturais dos negros37 e europeus na construção da concepção de Educação Física a partir da capoeira, do batuque, da mancala e da ginástica. Todavia, como representação da classe hegemônica, em 1851, optou-se pela inclusão desta última opção, a ginástica nos currículos escolares38. Assim, seguiram-se anos com práticas de caráter higienista, em vistas à manutenção do "corpo saudável" apto para o trabalho39 e no período da ditadura militar, passou-se a esportivizar a Educação Física como propaganda de força e poder do governo. Enfim, nas décadas de 80 e 90 a Educação Física passou a ser rediscutida criticamente com o objetivo de traçar outros rumos para a área.

As relações de poder da sociedade convergem para o corpo40, que é objeto e sujeito em discussão na Educação Física. Ante o exposto, percebe-se que há algum tempo, a Educação Física contribui politicamente nos processos de formação dos sujeitos em vários campos da sociedade, inclusive do sujeito trabalhador da EAJA. Presente hoje nos currículos escolares dessa modalidade de ensino, a Educação Física sofre influência de todas essas concepções e não é por acaso que está intrinsecamente, relacionada ao mundo do trabalho.

Assim, compreende-se a Educação Física como um fenômeno sócio-políticocultural que estuda as formas de expressão do corpo e pelo corpo, como uma linguagem de comunicação consigo e com o mundo, permeada pelos conceitos e representações da corporeidade e da cultura corporal.

A corporeidade é compreendida por duas conceituações complementares:

[...] a primeira [...] uma expressão, considerando que todo evento experimentado pelos sentidos deixa no corpo marcas que são

37 "A cultura negra pode ser vista como uma particularidade cultural construída historicamente por um grupo étnico específico, não de maneira isolada, mas no contato com outros grupos e povos” (GOMES, 2003).

38 (VALENTE, 2009).

39 A "força muscular do trabalhador sua energia e resistência passaram a ser objeto de exploração", reduzindo o trabalho a simples ação fisiológica, desprovida de criatividade (GONÇALVES, 1994).

40 “(..) sobre o corpo se encontra o estigma dos acontecimentos passados (...)” “(...) Ora, não é o consenso que faz surgir o corpo social, mas a materialidade do poder se exercendo sobre o próprio corpo dos indivíduos." “(...) O poder penetrou no corpo, encontra-se exposto no próprio corpo (...)”. FOUCAULT, Michael. Microfísica do Poder. Rio de Janeiro, Graal, 1979, p. 15, 82 e 83. 
expressas por uma linguagem, que se traduz em movimentos. A segunda por considerar como uma ferramenta didática para olhar esse corpo (GOMES, 2004, p. 03).

Cultura corporal41 pode ser compreendida como os conhecimentos historicamente construídos pela Educação Física42 na sociedade, conhecimentos que são referenciados nas danças, nas ginásticas, nos jogos e brincadeiras, nos esportes, nas lutas, nas linguagens corporais expressivas e exploração de movimentos que conferem identidade à Educação Física escolar43 e aos demais saberes que se inter-relacionam à esse fenômeno sócio-políticocultural44. Contudo, os elementos da cultura corporal devem ser norteados por caracterizações dessas modalidades, tendo em vista sua dimensão de linguagem expressiva e a sua aplicação no âmbito escolar, como se pode observar a seguir:

O esporte deve ser compreendido como uma prática social para todas as pessoas. (BRASIL, 1988; VIEIRA, 1997, p.68)..

A dança pode ser considerada como uma "linguagem social" (Coletivo de autores,1992, p.83), “um signo" (Wosien, 2000, p.27). A dança é a expressão representativa de diversos aspectos da vida do homem, acompanha-o ininterruptamente através de sua história em todos os momentos de sua existência, servindo como elemento de comunicação e afirmação [...] através de seu próprio corpo (CAMILO, 1999).

O conceito de jogo é complexo, pois pode assumir diversas formas e permear vários elementos da cultura corporal, todavia, pode-se afirmar que o jogo é o resultado de um sistema lingüístico (BROUGÈRE E HENRIOT, apud. KISHIMOTO, 1999) dotado de regras, que acontece dentro de um determinado contexto social através de nenhum, um ou vários objetos em uma intenção lúdica do jogador (KISHIMOTO, 1999).

As ginásticas são um conjunto de técnicas específicas de exercício que objetivam o trabalho individualizado e/ou coletivo, requerendo para tanto, a consecução de movimentos com determinados grupamentos musculares individualizados ou em sequiência passíveis de aplicação a diversos objetivos e finalidades. (MEC, 1997)

\section{1 (BRACH, 1992).}

42 Outros estudos reconhecem a Educação Física escolar "enquanto campo de vivências e experiências sociais que trata no interior da escola de temas da cultura corporal" (GRANDO, 1997, p. 13)

43 GOMES, 2004, p. 05, concebe a Educação Física como "um espaço privilegiado de expressão corporal" onde "os movimentos constroem a cultura do grupo, fazendo conjugar as expressões de uma cultura corporal" (GOMES, 2004, p. 05).

44 "A cultura é uma dimensão do processo social, da vida de uma sociedade e por isso pode-se notar que a produção artística dessa sociedade dá-se toda através da cultura. Reflete-se na arte a expressão cultural de um povo". (CAMILO, 1999). 
As lutas são elementos culturais que se caracterizam pela disputa entre oponentes afim de que se desenvolvam estratégias de desequilíbrio, imobilização ou retirada de um dos oponentes de um determinado espaço. (MEC, 1997).

O objetivo principal da Educação Física como componente curricular para a Educação de Adolescentes, Jovens e Adultos é desenvolver os conhecimentos da corporeidade e da cultura corporal, com o intuito de formar sujeitos conscientes, autônomos, articulados, capazes de perceber, construir e relacionar conhecimentos 45 acerca da educação de seu corpo, compreendendo-o como uma práxis social, como uma linguagem46.

Dessa forma, a metodologia adotada deve utilizar as abordagens críticas da Educação Física, tendo como foco o objetivo acima descrito.

A mediação pedagógica parte dos elementos da cultura corporal e da corporeidade por permitirem ao professor obter o subsídio necessário para a sua ação pedagógica. A ação pedagógica na Educação Física compreende reconhecer no educando, em quais paradigmas ele construiu seus conceitos e vivenciou suas experiências com relação a essa área, às práticas corporais e ao seu próprio corpo. Assim, o conceito de Educação Física apresentado na presente proposta será trabalhado pelo professor visando romper com as dicotomizações (teoria/prática47, corpo/mente, social/individual) 48.

$\mathrm{Na}$ recuperação das histórias de vida dos alunos, tem papel importante a valorização das tradições culturais e do saber prático que os educandos detêm. Adquiridos na vivência familiar, comunitária ou profissional, esses saberes são de extrema importância à relação dos alunos com o meio físico e social; eles não podem, portanto, ser ignorados ou desqualificados frente aos conhecimentos transmitidos pela escola. $\mathrm{O}$ desafio que se apresenta ao professor é o de estabelecer conexões entre esses dois universos de conhecimento, permitindo que o aluno amplie suas possibilidades de atuação, fortalecendo sua

45 “ (...) o conhecimento é fruto das capacidades humanas de empreender transformações na natureza - a que chamamos trabalho - , de socializá-las através das várias formas de linguagem e vinculá-las a uma tradição cultural através da interação com os outros seres humanos” p. 18. (VAZ, apud. ALMEIDA, 2008, 36).

46 "A práxis social é lingüísticamente constituída, mas mesmo a linguagem precisa se comprovar, por meio dessa práxis, naquilo que se encontra dentro do horizonte por ela aberto (...)” p. 465-466. (HABERMAS, apud. ALMEIDA, 2008, p. 35).

47 Para os frankfurtianos, o valor de uma teoria depende de sua relação com a práxis. Isto significa que, para ser relevante, uma teoria social tem que estar relacionada às questões nas quais, num dado momento histórico, as forças mais progressistas estejam engajadas (...) (ALVES-MAZZOTTI, 2002, p. 116).

48 “(...) o ser humano é um ser indivisível, e toda a fragmentação o aliena. Portanto, é no ato da criação, que entram em jogo, capacidades e habilidades de percepção, formas de organização de conhecimentos e de reorganização de elementos. Entrelaçadas e inseparáveis das habilidades estão as motivações, emoções e valorizações, tudo isto transparecendo, em uma forma global, através da expressão corporal" (TAFFAREL, 1985, p.04). 
autoconfiança. É provável que esse processo faça emergir conflitos entre diferentes modos de ser. A diversidade de características dos educandos, que muitas vezes é vista como um obstáculo ao processo de ensino-aprendizagem, deve ser compreendida como uma oportunidade para que o educador enfrente com o grupo, os preconceitos e discriminações sociais, desenvolvendo valores e atitudes de solidariedade e de respeito às diferenças de gênero, geração, etnia e até, de estilo de vida.

O procedimento didático nas aulas de Educação Física pode ser estruturado através de processos tematizadores49, fato que irá respeitar as competências do educando e ampliar suas habilidades através da experimentação científica e/ou representação simbólica, da verificação in loco das possibilidades de transformações de si e do seu meio, de seu corpo e das relações que construirá a partir desse momento. No processo de tematização o professor precisa conhecer o assunto, desenvolver estratégias mediadoras, estabelecer relações entre a atualidade do saber e sua gênese histórica, e ter claro que o conhecimento possui níveis diferenciados de complexidade.

É importante ressaltar que as temáticas teóricas trabalhadas pelo professor, devem ser problematizadas e vivenciadas também, de forma prática pelo aluno, dentro das possibilidades objetivas e subjetivas existentes, através dos diferentes elementos da corporeidade e da cultura corporal, para que o educando possa se apropriar das informações por diferentes vias perceptivas aferentes e elabore o seu conhecimento a partir da práxis educativa, ou seja, da experimentação científica, da união da prática com a teoria.

Para tanto, a aula deve ser concebida como um espaço aberto50 ou flexível, onde se promove, efetivamente, o ensino, a aprendizagem e a totalidade do ato pedagógico. Este espaço deve ser pensado como um micro-lugar educacional e relacional, onde se estabelece um diálogo mediador entre o educador e os educandos na organização e reorganização dos conteúdos de ensino e processos de aprendizagens.

As exigências da organização da proposta político pedagógica da EAJA apontam para processos coletivos plenamente articulados, tanto no ensinar como no aprender em

49 O processo de tematização está consubstanciado na tendência pedagógico Crítico- Superadora desenvolvida na obra: BRACH, 1992.

50 Conceber a aula como um espaço aberto significa "romper" com as paredes da escola, estabelecendo inter-relações reflexivas e criativas entre os saberes constitutivos da cultura escolar, as questões que envolvem a realidade sócio-cultural e as necessidades e perspectivas dos educandos. Nesta perspectiva, todo o ensino deve estar orientado para os processos que fortaleçam a participação, a criatividade e a co-responsabilidade do educando na ação educativa e estar vinculado aos objetivos e compromissos estabelecidos pelo Projeto Pedagógico da Escola. 
contextos interdisciplinares na escola. Desta forma, a prática pedagógica da educação física exige ações que fortaleçam EAJA, sobretudo, na utilização do tempo pedagógico, na aplicação de metodologias de ensino e na avaliação51.

De acordo com esta proposta, educar exige dos educadores novos compromissos com a ação pedagógica, materializados no planejamento coletivo, na organização integrada de saberes, na reflexão sistematizada das práticas e na avaliação, numa perspectiva de totalidade, pautada em teorias, procedimentos e vivências, integrados ao Projeto Político Pedagógico da Escola, que possibilitem a formação social e crítica dos sujeitos.

\section{Objetivos Gerais:}

- Compreender a importância da Educação Física e da influência do processo de escolarização na apropriação da cultura corporal, a saber, danças, esportes, ginásticas, lutas e jogos.

- Proporcionar vivências e discussões dentro do componente curricular da Educação Física que sejam importantes para o enriquecimento do repertório cognitivo do aluno, de modo que, ele faça uso desses conhecimentos para a sua vida e atue como disseminador dos mesmos em seu meio.

- Perceber o aluno da EAJA como sujeito portador de uma história pessoal que envolve o conhecimento de alguns elementos da cultura corporal e acrescentar outros elementos importantes para a sua vida.

- Despertar e incluir o aluno no processo de ensino e aprendizagem, como sujeito de conhecimento que estabelece uma relação prévia pautada sobre valores atribuídos à sua corporeidade e à cultura corporal e que pode expandir essa relação a partir de seu envolvimento e interesse.

- Promover o diálogo como elemento mediador das relações entre os sujeitos envolvidos no processo de ensino-aprendizagem.

- Conhecer, valorizar, respeitar e vivenciar a pluralidade de manifestações da cultura corporal do Brasil e do mundo, percebendo-as como valioso recurso expressivo para a leitura e compreensão de mundo, para a qualificação das relações entre pessoas e entre os diversos grupos sociais.

- Orientar e auxiliar na identificação e correção problemas de ordem corporal em diferentes contextos, regulando e dosando o esforço físico em um nível compatível com as

51 Cf. Avaliação p.42 
possibilidades pessoais, considerando ainda, que o aperfeiçoamento e o desenvolvimento das competências corporais decorrem da perseverança e regularidade de suas práticas, e estas, devem ocorrer de modo saudável, equilibrado e harmônico.

- Conhecer os diversos padrões de saúde, beleza e estética corporal existentes, perceber a influência que esses padrões sofrem a partir dos diferentes interesses políticos e econômicos; compreendendo-os de forma crítica e saudável.

\section{MATEMÁTICA}

Alfabetizar-se em Matemática, na escola, e fora dela, é compreender as linguagens que ela apresenta, para que haja comunicação e interação do sujeito com a realidade em que vive.É compreender o que se lê e escreve a respeito das noções de números e operações, espaço e forma, grandezas e medidas e tratamento da informação.

Como construção lógico-dedutiva, como exercício do pensamento ou como auxiliar na experiência humana, o conhecimento matemático permeia a linguagem e as práticas cotidianas. Para alguns desperta interesse e instiga, para outros pode ser indiferente. Mas, para muitos, a apropriação (ou não) do conhecimento matemático, pode interferir no processo geral de aprendizagem, gerando, em muitas situações, dificuldades, rejeição e pouco aproveitamento.

A educação de jovens e adultos, constantemente, se depara com especificidades que envolvem conhecimentos relacionados às práticas sociais dos educandos. É desejável que a escola esteja atenta a essas especificidades buscando desenvolver um projeto pedagógico que explore e amplie as possibilidades de sua inserção e atuação no mundo letrado.

O ensino de matemática na EJA, segundo Ribeiro (1997) e Brasil (2002), deve incorporar à prática pedagógica, os conceitos, as atitudes e os procedimentos matemáticos desenvolvidos em meio às vivências dos alunos, os quais emergem em meio às suas inteirações sociais, experiências profissionais e pessoais e integram a sua bagagem cultural. Esses elementos se desenvolvem e constituem nas suas práticas sociais com a matemática que, por sua vez, estão inseridas nas práticas de leitura e escrita demandadas por nossa sociedade grafocêntrica. Fonseca (2002, 2004, 2005).

Dessa maneira, faz-se necessário incorporar à Educação Matemática os conhecimentos e procedimentos construídos e/ou adquiridos nas leituras que esses sujeitos 
fazem do mundo e de sua própria ação nele, de maneira a expandir e diversificar as suas práticas de leitura do mundo, possibilitando um acesso mais democrático à cultura letrada (Fonseca, 2002, p. 59). O professor de matemática passa, assim, a concebê-la como um meio: ele educa por meio da matemática, visa a formação do cidadão e questiona que matemática e ensino são adequados e relevantes nessa ação.

Paulo Freire preocupa-se com o educando inserido no contexto social, a partir do qual se dá a inserção dos conteúdos. Tais reflexões são compartilhadas também pelos educadores matemáticos, contribuindo em redefinir o campo, o objeto de estudo e as novas diretrizes para a Educação Matemática. Elas,conforme D”Ambrósio (2002), defendem o desenvolvimento de atividades motivadas, orientadas e induzidas a partir do meio.

Estudos desenvolvidos por Souza (1992), Floriani (2000), Skovsmose (2002) e muitos outros pesquisadores, com atuação em diferentes contextos, defendem quatro pontos fundamentais à Educação Matemática: contextualização do ensino, respeito à diversidade, desenvolvimento de habilidades e reconhecimento dos fins científicos, sociais, políticos e histórico-culturais.

Para se enxergar e aceitar os educandos como diferentes e também conhecê-los mais, para compreender as suas expectativas e os seus procedimentos, no momento em que eles se defrontam com o contexto escolar, se justificam as abordagens da Educação Matemática: a Etnomatemática; a Modelagem Matemática; a História da Matemática; a Resolução de Problemas e os Jogos e Tecnologias Educacionais, por serem, essas metodologias, na atualidade, foco de discussão e de utilização no âmbito do ensino e da aprendizagem em Matemática.

A Etnomatemática vê a matemática como uma produção cultural contextualizada. Analisa, portanto, a sua presença nos contextos da vida cotidiana. Assim, o adulto trabalhador, elaborador de conhecimentos e técnicas, é um produtor de cultura no seu contexto de vida. Esse reconhecimento passa a ser uma ferramenta poderosa no resgate da auto-estima do aluno que, como se sabe, é favorecedora da aprendizagem.

Estudar os conhecimentos matemáticos dos educandos jovens/adultos no momento em que esses se defrontam com o contexto escolar não significa, entretanto, classificar, de forma dicotômica o escolar e o não escolar. Significa sim, aprofundar o conhecimento sobre todos esses saberes adquiridos na vida doméstica, profissional, ou até na experiência escolar passada e como interagem na construção do conhecimento matemático desses sujeitos. 
A Resolução de Problemas, de forma contextualizada, tem sido um tópico presente nos currículos de Matemática. Pompeo (1999, p. 208 ) diz: “quando os professores ensinam matemática, através da resolução de problemas, eles estão dando a seus alunos um meio poderoso e muito importante de desenvolver sua própria compreensão” ou seja, compreender deve ser o principal objetivo do ensino. Dessa maneira, à medida que os alunos aumentam sua compreensão, suas habilidades matemáticas na resolução de problemas também aumentam e vice versa. Freire (1996 p. 26-35) afirma:

Não temo dizer que inexiste validade no ensino em que não resulta um aprendizado em que o aprendiz não se tornou capaz de recriar ou de refazer o ensinado. [...] nas condições de verdadeira aprendizagem os educandos vão se transformando em reais sujeitos da construção e da reconstrução do saber ensinado [...].

Assim, o professor pode propor, ao educando, situações problemas caracterizadas por investigação e exploração de novos conceitos e ele, o educando, pode formular problemas para que seus colegas os resolvam, tornando a matemática um conhecimento mais próximo desses sujeitos.

A modelagem matemática e a modelação têm rompido a dicotomia existente entre a matemática da escola formal e a da vida real. Elas acontecem quando o educador leva os educandos até os problemas da vida real e, juntos, elaboram os modelos matemáticos possíveis para a resolução do problema apresentado. Trabalhar com a Modelagem Matemática não é apenas uma questão de se ampliar os conhecimentos mas, sobretudo, de estruturar a maneira de pensar e agir.

A história da Matemática possibilita a visão sobre a natureza do conhecimento e da atividade matemática; contribui para elaboração de atividades significativas e promove a visão da matemática como uma atividade humana e cultural; promove o despertar do interesse e gosto pela matemática pois a construção histórica do conhecimento leva a uma maior compreensão da evolução do conceito trabalhado, minimizadando as suas dificuldades epistemológicas.

A informática na educação é importante por que, ao longo da história, diversos instrumentos "tecnológicos" foram criados por todas as civilizações e diversas tecnologias revolucionaram a educação como o livro impresso, os aparelhos de som, o videocassete, os televisores e o computador. Segundo Borba (2003, p.59), o acesso à informática deve ser visto como um direito de todos. Assim, a educação deve, hoje, contemplar, no mínimo, uma “alfabetização tecnológica” compreendida como aprender a ler a nova mídia. 
O uso de calculadoras, computadores e outros elementos tecnológicos, traz significativas contribuições à medida que relativiza a importância do cálculo mecânico e da simples manipulação simbólica. Cálculos feitos de modo mais rápido e eficiente evidenciam a importância da linguagem gráfica e de novas formas de representação, permitindo novas estratégias de abordagem dos problemas. Isso instiga, nos educandos, um crescente interesse por projetos e atividades de investigação, permitindo que construam uma visão macro da verdadeira natureza da atividade matemática e desenvolvam atitudes positivas diante de seu estudo.

Os sujeitos da EAJA trazem consigo muitas habilidades matemáticas elaboradas no dia a dia, nas atividades profissionais, ou mesmo na administração de suas necessidades de sobrevivência. Tais habilidades precisam ser explicitadas, a cada conteúdo abordado, para ser possível a interação com os saberes sistematizados e constituídos os significados dos mesmos em suas rotinas pessoais.

Dessa forma, não se pode pensar numa lógica que define, como prioridade, apenas um conjunto predeterminado e definido de regras e processos destinados à resolução de operações. Vários aspectos da Matemática devem ser abordados com adultos que vêem de experiências muito diversificadas. À medida que se fizer necessário, as operações podem ser usadas como meios contextualizados para resolver os desafios apresentados.

Na EAJA é de suma importância que se trabalhe a leitura, a interpretação e a produção de textos matemáticos e os jogos, bem como os conceitos e procedimentos inerentes aos números, à geometria, à álgebra, às grandezas, à proporcionalidade, ao raciocínio combinatório, estatístico e probabilístico, sem a preocupação com a lógica linear dos conteúdos. Tais conhecimentos e ou habilidades podem ser trabalhados, à medida que se fizer necessário, num planejamento interdisciplinar de temáticas que envolvam todo o coletivo.

\section{HISTÓRIA}

Pensar o ensino de história para os sujeitos adolescentes, jovens e adultos numa época marcada pelo pragmatismo e pelo utilitarismo da ciência, consiste em desafio diante da necessidade de uma formação humana e política, num contexto de individualismo, fragmentação e desarticulação da participação coletiva. São muitas as inquietações postas aos sujeitos comprometidos com uma formação transformadora.

Qual é a importância do conhecimento histórico na atual sociedade conduzida 
pelo consumismo? Como construir o conhecimento histórico como prática social, na sociedade globalizada? Como trabalhar o conhecimento histórico no sentido de produzir nos sujeitos singulares a humanidade que é produzida histórica e coletivamente? Essas e outras tantas indagações permeiam as preocupações dos professores de história e do ensino na RME.

O ensino de história na EAJA deve considerar como ponto de partida a historicidade do sujeito. Significa reconhecer que o sujeito da EAJA traz consigo muito mais do que um acúmulo de conhecimentos, mas também uma história de vida e uma identidade. Essas pessoas de alguma forma vêm tecendo sua história e carregam experiências do contexto de cada tempo vivenciado.

Reconhecer o sujeito da EAJA como um sujeito histórico não significa apenas constatar essa verdade, mas adotar metodologias para que esse educado se compreenda como ser histórico, na inter-relação com o outro, constituindo assim suas identidades pessoais e coletivas. Assim, podemos afirmar que: "O verdadeiro potencial transformador da história é a oportunidade que ela oferece de praticar a inclusão histórica" (PINSKY, 2007, p.28) e possibilitar aos sujeitos a reescrita e a ressignificação da sua própria história.

Uma educação histórica se estabelece nas relações possíveis entre o procedimento histórico e o saber escolar. Portanto, interpretar a história, a partir da identidade sócio-cultural dos sujeitos, significa romper com a concepção hegemônica de história, profundamente reprodutivista e determinista, que prioriza a descrição do passado, cujo objeto principal é a memorização e a formação de indivíduos eruditos (BLOCH, 1997).

Um procedimento fundamental para o fazer histórico é a concepção de temporalidades históricas. É preciso compreender o tempo não apenas como uma continuidade cronológica, em que os fatos se encadeiam e se relacionam, reproduzindo uma visão determinista e eurocêntrica.

O sujeito da EAJA deve compreender as diversas temporalidades do processo histórico, sua relação com as organizações sociais e os conflitos produzidos pela sociedade humana. Torna-se, portanto, necessário, considerar a multiplicidade do tempo, suas uniformidades e regularidades, suas rupturas e mudanças. Enfim, é necessário desenvolver a capacidade de problematizar os acontecimentos históricos sob às inquietações do presente.

Esse modo de compreender o tempo histórico produz uma ruptura com a concepção linear e cronológica da história, imperativo na ressignificação do currículo. Acredita-se que o currículo de história é uma forma de elaboração do processo histórico, uma vez que a história é continuamente escrita e reescrita, visto que a interpretação que se faz dos 
acontecimentos, muitas vezes, ocorre desvinculado do seu tempo e, portanto, sofre as influências e determinações de um outro tempo, o do interpretante. Sabe - se que o fazer histórico e o currículo não são neutros e não apreende a totalidade dos acontecimentos históricos.

Dessa forma, a seleção dos conteúdos que vão compor o currículo da EAJA deve partir das vivências e interesses dos sujeitos que compõe essa modalidade, portanto ele deve se estabelecer em uma perspectiva contextual, relacionando saberes socialmente produzidos pelos sujeitos e realidades determinadas pela conjuntura imediata, com saberes historicamente construídos pela sociedade humana ao longo do tempo. Na perspectiva da valorização de todos os componentes curriculares, pressupõe-se articular um trabalho baseado em experiências intencionais entre as disciplinas e a produção coletiva de conhecimentos.

O fazer histórico deve se pautar pela reinterpretação do passado à luz de diferentes evidências do presente. Um dos objetivos do ensino de história na EAJA é que o sujeito faça algumas inferências que o leve a compreender o fato em si e sua relação com seu cotidiano. É preciso ter uma atenção especial à natureza das fontes, elas devem expressar as culturas, modos de vida e relações sociais em temporalidades distintas.

Em uma relação dialógica com os alunos, é importante selecionar o tema, buscar as fontes e formas, como aquele tema foi interpretado e finalmente em uma relação dialética discutir e sistematizar as informações desenvolvidas e a partir dos referenciais teóricos, buscar compreensões e olhares diversos sobre a realidade.

Um procedimento central para o desenvolvimento do fazer histórico na EAJA é estabelecer uma relação dialógica entre os saberes históricos e eixos da proposta: cidadania, trabalho, cultura e identidade. Neste contexto, deve-se ressaltar positivamente a efetiva participação dos povos africanos, indígenas e quilombolas no processo histórico-cultural brasileiro, de modo a produzir uma ruptura com a visão eurocêntrica/etnocêntrica dominantes, inclusive nas abordagens cientificas, como assegura a Lei Federal $n^{\circ} 11.645$ de 10 de março de 2008 que alterou a LDBEN/9.394/96, estabelecendo a obrigatoriedade do ensino sobre História e Cultura Afro-Brasileira e indígena nos estabelecimentos de ensino fundamental e médio, oficiais e particulares.

Assim, ensinar história é reconhecer o verdadeiro papel do negro e do índio na formação cultural brasileira, compreender a cultural africana e indígena e os seus legados históricos para a humanidade. Um ensino de historia crítico e dialético deve dar conta de identificar e desconstruir os mecanismos de produção do racismo, do preconceito e da 
discriminação existente na sociedade e no espaço educacional, bem como de produzir espaços de reflexão sobre as lutas históricas desses povos e ampliar as conquistas desses movimentos para além das políticas afirmativas. O ensino de historia deve considerar a totalidade da formação histórica e cultural do país e, com efeito, os atores que dela participaram.

O ensino de história deve contribuir para a emancipação dos sujeitos, portanto deve refletir, com eles, os processos de participação e organização da sociedade bem como as relações de trabalho. Dessa forma os fatos históricos devem ser referenciais para que o sujeito possa compreender as relações de exploração e produção em que estão inseridos.

O desenvolvimento do saber histórico na EAJA parte do reconhecimento da diversidade cultural e das identidades dos sujeitos. Reconhecer a diversidade não é só aceitar ou tolerar outro, mas estabelecer ações transformadoras, reconhecendo a singularidade das culturas e buscando formas de superar as desigualdades.

Por outro lado, é necessário fortalecer a identidade dos sujeitos valorizando os elementos regionais e a memória coletiva, enfatizando tanto os saberes e tradições, como a própria história regional, que deve ser um dos pilares para romper com o determinismo eurocêntrico e etnocêntrico da historiografia tradicional. Partir da identidade cultural e regional do sujeito é um caminho para se construir um currículo contextualizado.

Por fim, o fazer histórico também precisa se integrar a outras linguagens, visando contribuir com a formação integral dos sujeitos. Cabe à história desenvolver procedimentos que favoreçam a aquisição e ampliação das potencialidades de leitura e escrita, portanto, das possibilidades de letramento do aluno. A escolha dos documentos históricos deve priorizar, também, a possibilidade do aluno de conhecer e manusear diversos tipos de gêneros textuais, ampliando, conforme Freire (1987), sua "leitura da palavra e de mundo".

\section{LÍNGUA ESTRANGEIRA}

A história do Ensino de Línguas foi constituída, em determinados momentos, por diferentes concepções de aprendizagem/aquisição de línguas estrangeiras o que resultou em diversos métodos/abordagens. Dentre elas, vale destacar três que exerceram, e exercem até hoje, grande influência no ensino de língua estrangeira.

Desde o século XVIII, predominou o uso da Abordagem Gramatical, através do método de Gramática e Tradução, o qual enfatizava a memorização de vocabulário, as regras gramaticais e traduções de textos. Por volta de 1950, foi adotado o Audiolingual que tinha 
como princípio teórico o behaviorismo, logo a língua era considerada como um conjunto de hábitos. Nesse modelo, enfatizava-se as atividades orais para conversação rápida, prática de pronúncia e exercícios repetitivos através de estímulo e resposta.

A partir dos anos 70, surgiu a Abordagem Comunicativa, propondo uma metodologia mais humanista, priorizando "um processo interativo para o Ensino de Línguas" (Maia et. all, 2002). Assim, na abordagem comunicativa a concepção da língua ganha um outro significado, pois

[a] ênfase da aprendizagem não está na forma lingüística, mas na comunicação. As formas lingüísticas serão ensinadas apenas quando necessárias para desenvolver a competência comunicativa e poderão ter mais ou menos importância do que outros aspectos do evento comunicativo. $\mathrm{O}$ desenvolvimento de uma competência estratégica - saber como usar a língua para se comunicar - pode ser tão ou mais importante de que a competência gramatical (LEFFA, 1991, p 226).

Dessa forma, o ensino de línguas deve contemplar uma perspectiva que considere a inserção do educando em discursos usados em diferentes contextos sociais. Desse modo, o professor deve organizar:

experiências de aprender em termos de atividades relevantes / tarefas de real interesse e/ou necessidade do aluno para que ele se capacite a usar a línguaalvo para realizar ações de verdade na interação com outros falantes-usuários dessa língua (ALMEIDA FILHO, 2002, p 36).

Essas atividades devem contemplar, ainda, as habilidades de leitura, escrita, compreensão oral e fala, enfocando as suas diferenças no uso da língua em diversos países a partir das variedades lingüísticas, estruturas gramaticais, vocabulário e aspectos culturais, reforçando o seu papel na concepção de sociedade.

O trabalho pedagógico poderá ter como foco inicial a leitura de textos, podendo ser exploradas além das estratégias de leitura, os gêneros textuais (entrevistas, textos publicitários, cartas, história em quadrinhos, instruções, anúncios, rótulos, reportagens, classificados, poemas, editoriais de jornal, artigos, verbetes de dicionários, receitas e outros), suas características e as funções da linguagem.

Vale ainda ressaltar que, a língua estrangeira também visa contribuir no processo de aprendizagem, proporcionando ao aluno a sistematização de um novo código lingüístico que o auxiliará na compreensão de sua própria língua. Nesse sentido, a escrita padrão da língua estrangeira precisa fazer parte da dinâmica diária das aulas, podendo ser os textos de tipos variados: literários (poema, romance,etc.); científicos (relatório de pesquisa, trabalho 
publicado em revista científica etc.); epistolares (carta pessoal, carta de negócio etc.); de propagandas (anúncio para vender uma TV); etc.

A oralidade não deve ser negligenciada no conhecimento de uma língua estrangeira. Sendo assim, devemos trabalhar as atividades orais, afim de que os alunos percebam os diferentes sons da língua através de saudações, letras de música, poemas, diálogos, dentre outros recursos possíveis. O objetivo principal do trabalho oral em sala é proporcionar situações comunicativas nas quais os educandos possam vivenciar a linguagem apropriada em momentos diversos do ato de fala, além de exercerem os diferentes papéis lingüísticos exigido nas ações sociais.

A partir dessa perspectiva, os materiais devem atender, da forma mais próxima possível, as situações em que os educandos possam perceber como os materiais considerados "autênticos" são estruturados, diferentemente dos materiais produzidos para fins exclusivamente didáticos. Estes são organizados com a finalidade de demonstrar um tópico específico do tema proposto, limitando-se, algumas vezes, a determinado tópico gramatical ou ao vocabulário destinado aquele tema.

Portanto, a língua estrangeira na Educação de Jovens e Adultos deve proporcionar aos educandos além de uma contribuição na sua formação global, o acesso aos conhecimentos e as informações circulados na mídia, capacitando-os a intervir criticamente no mundo.

\section{LÍNGUA PORTUGUESA}

A linguagem é a primeira instituição com a qual o ser humano entra em contato

quando nasce. É por meio dela que ele vai se tornando um ser cultural, pois ela é carregada signos culturais, que o insere em um determinado tipo de sociedade (BERGER E LUKMAN...). Bastos (2007, p. 01), citando Saussure define linguagem, língua e fala como dimensões diferentes da comunicação humana. A linguagem é definida como "um sistema ou estrutura sígnica abstrato articulado, fenômeno universal, utilizado pelo humano, que o diferencia de outras espécies, tornando-o assim o homo loquens”. A língua significa para Bastos (2007, p. 01) “a manifestação cultural da linguagem”. A língua "é então, um código sígnico articulado utilizado por um grupo ou uma comunidade humana específica” [...]. "A fala, por sua vez, é entendida como o modo particular e individualizado pelo qual o utente exercita a língua. A fala é o exercício material da língua levado a cabo por este ou aquele indivíduo pertencente a uma comunidade linguística especifica” (Bastos, 2007, p.01). 
Nas últimas décadas, o ensino de Língua Portuguesa passou por mudanças significativas quanto aos estudos realizados no campo da Lingüística que aponta três possibilidades preponderantes de conceber a linguagem: 1) como "representação", espelho do mundo e do pensamento; 2) como "ferramenta" de comunicação; 3) como forma de ação e de interação.

Essa última concepção aponta que o usuário da língua não a usa apenas para traduzir e exteriorizar um pensamento ou transmitir informações, mas para realizar ações, agir, atuar sobre o interlocutor. A linguagem é um lugar de interação que possibilita aos membros de uma sociedade a prática dos mais variados tipos de atos.

Para Bakhtim, a língua é um produto concreto de cunho social e aparece no uso dos signos que cada sujeito faz numa relação com o "outro". O estudo da língua volta-se para seu uso concreto, ou seja, como essa língua se concretiza nos enunciados elaborados pelos seus falantes. Na concepção enunciativa a língua é viva, produzida na história e produtora de histórias, revelando-se nas diversas práticas sociais, por meio dos gêneros do discurso. É preciso situar os interlocutores e o som emitido no meio social para que se compreenda a linguagem. Para ele: "a unidade do meio social e a do contexto social imediato são condições absolutamente indispensáveis para que o complexo físico-psiquico-fisiológico que definimos possa ser vinculado à língua, à fala e tornar-se de fato linguagem".

O educando da EAJA, ao chegar à escola, é portador de todas essas dimensões, o que ele não sabe, e constitui papel da escola, é como se organiza esse código verbal/escrito. A escola tem a função mediadora de ensiná-lo a transitar por esse código e, para que essa mediação seja bem sucedida, é necessário que a escola respeite a variedade linguística do educando marcada pelas suas experiências de vida e, ao mesmo tempo, possibilite a apropriação da variedade padrão da língua, pois vivemos numa sociedade grafocêntrica a qual exige pleno domínio da linguagem verbal: tanto a escrita quanto a oral.

Portanto, cabe ao professor de Língua Portuguesa possibilitar ao educando o contato com as variedades linguísticas, com a diversidade de usos da fala, trabalhando com os graus de formalidade e informalidade nas modalidades oral e escrita, para que ele se torne "poliglota" de sua própria língua.

Bakhtim defendia que os estudos lingüísticos deveriam ter como foco os enunciados realizados pelos falantes e que o conhecimento dos gêneros textuais que circulam no meio social dos falantes de uma língua é fundamental na realização da enunciação. Uma abordagem com foco nos gêneros do discurso permite perceber que a linguagem produz 
sentidos, acontece em situações sócio-comunicativas e tem intenções. A escolha da linguagem, as formas de dizer são concretizadas nos gêneros (orais ou escritos), "fenômenos históricos, profundamente vinculados à vida cultural e social. [...] São entidades sóciodiscursivas e formas de ação social incontornáveis em qualquer situação comunicativa". (Marcuschi, 2002).

O estudo dos gêneros textuais é primordial na escola, uma vez que ele serve de elemento articulador entre as práticas sociais e os objetos escolares e leva em consideração "seus usos e funções numa situação comunicativa". (Bezerra, 2002 p.41). Aprende-se a utilizar a língua a partir da análise reflexiva do funcionamento da língua em uso, isto é, a aprendizagem acontece por meio da seleção e escolha dos gêneros textuais em função das práticas e usos da linguagem.

É especificidade do ensino de língua portuguesa propiciar o uso da linguagem e reflexões sobre essa linguagem presente nos diferentes textos lidos e produzidos, sobre os recursos lingüístico-discursivos, as normas e regras próprias dessa língua.

Sendo assim, o ensino de Língua Portuguesa embasado nos gêneros do discurso visa "instrumentalizar o aluno, provendo-o com as manifestações culturais de seu país em que o ensino de língua embasado nos gêneros do discurso visa o domínio diversificado da língua materna, expoente máximo da cultura, é fundamental para derrubar cercas, extrapolar limites, ultrapassar obstáculos e ganhar o mundo com a consciência de seu poder e de sua força" (Pereira, 2002.p.259).

Para o educando atuar na sociedade e refletir sobre ela é necessário que compreenda os mecanismos e as estratégias de leitura, interpretação e escrita da língua materna. Esse aprendizado se dá por meio do fazer pedagógico em que professores e alunos se encontram, especialmente, no âmbito escolar, mediados pela linguagem. Nesse encontro é importante que o educando se aproprie de forma dialética do objeto de estudo: a Língua Portuguesa.

O estudo da língua materna é de fundamental importância, devido ao seu caráter transdisciplinar, uma vez que perpassa todas as áreas e é por intermédio dela que os educandos desenvolvem a aprendizagem dos demais conhecimentos escolares, aumentando sua consciência em relação ao estar no mundo e ampliando sua capacidade de participação social, no exercício da cidadania. É por meio da linguagem que se formaliza todo o conhecimento produzido nas diferentes áreas e que se explica a maneira como o universo se organiza. 
De acordo com Freire (2001), os assuntos selecionados para análise lingüística devem estar relacionados à realidade dos educandos da EAJA. Tal análise deve ser rica em significação, garantir a experienciação de diversas práticas de linguagem, de modo a sujeitálas a um constante processo de revisão e crítica. Esse estudo favorece a formação de uma estrutura específica de pensamento, com base na organização do código da língua portuguesa, que contribui no desenvolvimento de habilidades intelectuais e de comunicação.

Muitas vezes, os educandos não compreendem a dificuldade que sentem na elaboração escrita, sendo que, na fala, conseguem se expressar sem maiores complicações. Essa dificuldade ocorre, principalmente, pela diferença da dinâmica da comunicação oral e escrita. Bajard (1999, p.16), diz que "a palavra oral não é linear, ela implica uma sucessão que não permite voltar atrás. O que é dito, é dito definitivamente." Ela é flexível, permite que um sujeito interrompa a fala do outro, sem comprometer a compreensão do diálogo anterior e nem dificultar a retomada do diálogo em curso, porque já se estabeleceu a comunicação.

A dificuldade do aluno é compreender que a escrita, ao contrário da oralidade, é linear. Ela impõe uma direção e uma estrutura: começo, meio e fim. Na produção de texto, o aluno pode retomar a escrita e corrigir as ambiguidades, a falta de coesão e coerência. Já na leitura, o educando pode usar as mesmas estratégias que ele usa na oralidade, "o olhar pode deslizar para frente, frear, voltar atrás. Pode mesmo saltar para outro parágrafo" (BAJARD 1999, p.16). No entanto, uma estratégia não linear de leitura prejudica a compreensão, pois uma leitura crítica exige que o leitor fique atento e dialogue com o texto a partir de seus conhecimentos prévios.

Daí, a necessidade de se trabalhar o confronto entre a língua que se fala na escola (língua padrão) e aquela que os educandos trazem das suas vivências, possibilitando-lhes a convivência com a escrita, como também a valorização e o reconhecimento da identidade lingüística de cada um (MEC: 2002).

A ampliação do uso da palavra e o domínio do discurso nas diversas situações comunicativas ajudam a compreender melhor o mundo, entender a dinâmica da organização social, interpretando, assim, as entrelinhas de seu funcionamento. As experiências de escrita e leitura, bem como o exercício freqüente de expressar idéias oralmente e por escrito, são ações básicas que estimulam novas descobertas e ajudam na elaboração e difusão dos conhecimentos. A leitura ou a formulação de um texto é, antes de tudo, uma prática social que se dá na interação com o outro. A Língua Portuguesa tem o papel, na escola, de conscientizar os educandos desse processo (MEC:2002), para que assumam a palavra como cidadãos e 
usem a leitura e a escrita em práticas discursivas que não envolvem necessariamente atividades específicas de leitura e escrita, mas que possibilitam a participação social. Assim, segundo Carvalho ( 2005 ) “ letrado é alguém que se apropriou suficientemente da escrita e da leitura a ponto de usá-la com desenvoltura, com propriedade, para dar conta de suas atribuições sociais e profissionais."

A leitura traz uma riqueza de possibilidades, que não só oferecem informações sobre realidade, mas colocam os leitores em contato com experiências de outros grupos, vivenciam desejos e sonhos que pareciam impossíveis, expressam com clareza sentimentos que antes não conseguiam traduzir, além de conhecerem a história de outros que vieram antes e compartilharem, com os de agora, os novos tempos e seus desafios.

A impossibilidade de acesso e reflexão sobre a linguagem é uma forma de exclusão. Por isso, Freire (2001) afirma que em uma sociedade como a brasileira que exclui dois terços de sua população, a questão da leitura e da escrita deve ser compreendida como um direito e deve constituir-se como luta política dos sujeitos no enfretamento dos mecanismos de exclusão das classes populares.

Para evitá-la, o ensino da Língua Portuguesa na EAJA deve, em primeiro lugar, servir para reduzir a distância dos educando com a língua padrão, possibilitando sua inserção na sociedade e no mundo do trabalho. O estudo da língua portuguesa, deve ajudá-los a incorporar uma visão critica das condições sociais de existência que produziram a sua exclusão e, ao mesmo tempo, deve, também, fortalecer a voz dos muitos jovens e adultos que retornam à escola para que possam romper os silenciamentos impostos pelos perversos processos de exclusão do próprio sistema escolar, capacitando-os a produzirem respostas aos textos que escutam e lêem, pronunciando-se oralmente ou por escrito.

\section{Objetivos Gerais}

- “Ampliar domínio ativo do discurso nas situações comunicativas, sobretudo nas instâncias públicas de uso da linguagem, de modo a possibilitar sua inserção efetiva no mundo da escrita, ampliando suas possibilidades de participação no exercício da cidadania". (PCN. p 32).

- Possibilitar o desenvolvimento da competência comunicativa e discursiva e da capacidade de utilizar a língua, adequando-a ao contexto, às diferentes práticas e situações sociais. 
- Ampliar e aperfeiçoar as possibilidades de uso da linguagem em situações sóciocomunicativas, tendo em vista dominar os procedimentos adequados de expressão oral e escrita.

- Desenvolver habilidades de leitura, utilizando estratégias como: análise, seleção, antecipação, inferência e verificação.

- Propiciar a apropriação dos recursos lingüístico-discursivos na construção dos gêneros textuais.

- Analisar e produzir textos orais e escritos de variados gêneros, observando as características, estrutura composicional, intencionalidade discursiva , finalidade, interlocutores e variedade lingüística.

- Desenvolver as habilidades de falar e ouvir, visando à participação em eventos de comunicação pública.

- Desenvolver a competência escrita, observando os elementos envolvidos no contexto de produção ( assunto, interlocutor,intenção e linguagem)

- Ler, compreender, interpretar e produzir variados gêneros textuais que circulam no contexto social, analisando suas diferentes estruturas e tipologias.

GEOGRAFIA: 


\section{Geografia}

A Geografia é um conhecimento que surge com o próprio homem, antes de definir a palavra Geografia, os homens já possuíam habilidades geográficas que nasceram da observação da natureza.

Para Lacoste (2004), a institucionalização do campo científico da geografia e sua popularização como disciplina obrigatória nas redes de ensino surgiram no século XIX. O controle de informações sobre o espaço como instrumento de poder das minorias dirigentes do Estado, fazia parte da tarefa desenvolvidas nas universidades,surgia assim um importante instrumento para o imperialismo. A geografia dos professores tinha como função a de mascarar a importância estratégica dos raciocínios centrados no espaço.

Essa "herança" da geografia do Estado, começou a ser questionada nas décadas de 1960 e 1970, por uma corrente que ficou conhecida como geografia criitica ou radical. No Brasil nos finais dos anos de 1970 e na década de 1980, que essa corrente começou a influenciar e promover o debate na geografia, a utilização do metodo dialético materialista nessa corrente permitiu mostrar as consequencias socias do desenvolvimento capitalista.

Essa corrente no ensino de geografia, produziu uma série de propostas que tinham como finalidade a afirmação do sujeito como agente da construção do seu próprio conhecimento.

Nessa perspectiva de analise as pesquisas de Rezende (1989) que enfocam o aluno trabalhador frente ao conhecimento fragmentário e conservador da geografia, aparecerem propostas de trabalhar a geografia a partir das transformações que ocorrem no espaço geográfico e a relação de interpretação que os alunos tem dessa realidade, esses se transformam sujeitos da sua própria história.

A utilização de categorias da geografia, com a finalidade de permitir a intermediação entre o conhecimento dos alunos e os conceitos científicos que envolvem essa categoria.

Para Cavalcante (2000) a utilização de categorias como Natureza, Sociedade,Lugar,Região,Território, poderiam ser utilizadas no ensino fundamental como formas de intermediar essa relação de aprendizagem, essa categorias precisam ser permeadas de uma forma que esses se tornem significativos e socialmente relevantes.

A Natureza é apresentada na perspectiva de sua totalidade, uma analise geográfica deve priorizar a dimensão física ( domínios morfoclimáticos) e humana. Segundo Gonçalves 
(1990) a natureza é uma produção humana, o ambiente é o todo dessa produção, a paisagem são as marcas registradas dessa relação, o belo o feio o intocável são adjetivos colocados conforme as necessidades que permeiam a sociedade, os educando do EAJA tem nessa analise a possibilidade de compreensão dessa realidade nas escalas locais, regionais, nacionais e internacionais,observando a inter-relação entre essas escalas.

Nessa dimensão os estudos a repeito do Cerrado se torna essencial nesse aspecto, a utilização da compreensão desse ambiente e sua interligação com as escalas,locais, nacionais e internacionais, deveram auxiliar o educando da EAJA, a entender as relações existentes no espaço socioeconomico de Goiás.

A sociedade é mostrada na perspectiva da uma luta de classes, o educando deve se perceber como elemento dessa dinâmica, quais os fatos presentes na organização da sociedade que influem na sua vida? A formação de uma resposta para esse questionamento permite ao educando perceber as relações sociais presentes na sociedade.

A dinâmica da Globalização entendida dentro do processo capitalista e as diferentes formas de resistência a esse sistema em vários locais do mundo mostram que uma outra globalização é possivel, conforme Milton Santos expõe em uma obra, , na qual a resistência de grupos locais e regionais contra a homogeinização desse sistema é uma forma possivel de criar uma globalização de principios sociais e humanos.

O lugar como categoria da geografia permite o desenvolvimento de problematizações, que mostram transformações sócias, vivenciadas pelo educando ao longo das sua existência e sua relação com as dinâmicas que influenciam esse lugar, fragmentações, diferenciações e antagonismos sociais compõem essas dimensões dessa categoria.

O lugar social, ultrapassa a visão de lugar de vivencia que evoca a "harmonia". Na compreensão dos conflitos que existem no lugar é que nos percebemos como agentes de transformação dessa realidade,o cotidiano para Damiani (1999)

O cotidiano segundo Damiani (1999) surge como um nível mediador entre o econômico e o político, no qual as relações se manifestão nessa dimensão que pressionam o social, as relações de solidariedade criam comportamentos que podem produzir uma autogestão desses lugares.

A cidade assume um papel fundamental, nessa perspectiva de analise do lugar.As cidades segundo Cavalcante (2002), se tornam fontes de processos pedagógicos que permitem que a cidadania seja uma construção desses espaços por sujeitos históricos que vivem e 
transformam o cotidiano dessa cidade. A compreensão dos espaços de construção histórico e social presentes nas cidades será uma fonte de analise constante do educando no EAJA.

A perspectiva de região na Geografia Critica, envolve segundo a analise de Corrêa (1994) o desenvolvimento da região no capitalismo que produz espaços regionais diferenciados porem em uma lógica que combina o desenvolvimento desigual e combinado. As diferentes formas de representação do espaço geográfico por meio de regionalizações, são formas de estimularmos nos educandos os questionamentos nas formas históricos de organizar esse pelo estado, também evidenciarmos outra formas de organização regional, contrapondo a essas, os territórios indigenas e quilombolas são formas de regionalizações que lutam para serem reconhecidas pelo Estado.

O mapeamento e a alfabetização cartográfica devem auxiliar nessa representação dessas categorias no espaço geográfico, a utilização de formas de interpretação da realidade além da escrita, tornam-se elementos importantes nesse processo de aprendizagem para o educando na EAJA.

\section{8- Estrutura organizacional}

Tendo como foco o atendimento às necessidades, anseios e especificidades dos educandos , a EAJA é organizada, primando pela formação integral desses e pelo seu pleno direito de exercício da cidadania.

\subsection{1- Programa AJA-Expansão - Alfabetização de Adolescentes, Jovens e Adultos}

10. Carga horária: $360 \mathrm{~h}$ anuais e $10 \mathrm{~h}$ semanais

11. Jornada letiva: $2 \mathrm{~h} 30 \mathrm{~min}$ diárias

12. Número de educandos por turma: mínimo de 15 e máximo de 25

13. Desenvolvimento de leitura e escrita contextualizada e pensamento lógico-matemático

14. Registro de avaliação: produção textual mensal.

15. Desenvolvido em locais alternativos, tais como empresas, sindicatos, igrejas, associações e outras instituições

16. Formação inicial com duração de 40 horas aula

17. Formação continuada: encontros semanais organizados em grupos que funcionam nos turnos matutino e noturno.

18. Acompanhamento mensal do coordenador aos respectivos grupos

19. Uma reunião semanal da coordenação, para reflexão e planejamento. 
20. Financiamento para participação em seminários, encontros e congressos.

\section{Educação Fundamental de Adolescentes, Jovens e Adultos de $1^{a}$ à $4^{a}$ série/Projeto $\boldsymbol{A J A}$}

(EM ESTUDO)

\section{Educação Fundamental de Adolescentes, Jovens e Adultos de $5^{a}$ à $8^{a}$ série - Base Curricular Paritária $^{52}$}

Carga horária: 200 dias letivos e 800 horas, assim distribuídas: 700 horas presenciais de efetivo trabalho em horário letivo seja dentro ou fora da escola, com a presença do educador e educando; 100 horas complementares por meio de trabalhos desenvolvidos fora do horário letivo pelo educando. Todos os componentes curriculares desenvolvem a mesma carga horária anual.

- $\quad$ Jornada letiva: $3 \mathrm{~h} 30 \mathrm{~min}^{\text {diárias }}{ }^{53}$

- $\quad$ Componentes Curriculares: Língua Portuguesa, Educação

Física, Artes, Ciências, Geografia, História, Matemática e Língua Estrangeira Moderna (Inglês).

- $\quad$ Número de educandos por turma: máximo de 35 em atendimento com 4 ou mais turmas

Atendimento de grupos com 4 ou mais turmas em Escolas Municipais Registro de avaliação realizado por notas de 0 (zero) a 10 (dez), bimestralmente, para cada componente curricular. (ver Regimento Escolar)

- Na Base Curricular Paritária de $5^{\mathrm{a}}$ à $8^{\mathrm{a}}$ série, com grupos de 04 (quatro) ou mais turmas o professor percebe $30 \mathrm{~h}$ semanais, com exceção do grupo de 04 (quatro) turmas que percebe $24 \mathrm{~h}$ semanais. A garantia do horário de estudo semanal se dá de formas diferenciadas quanto ao número de turmas.

- Coletivo de 07 (sete) turmas: aumento do número de professores passando de 08 (oito) para 09 (nove), sendo contemplados todos os 08 (oito) componentes curriculares.

52 Organização para escolas que possuem grupos com 4 ou mais turmas

53 A carga horária do educando é estimada, para efeito de transferência, no decorrer do ano letivo, multiplicando-se o número de dias letivos freqüentados por 4 (quatro), independentemente da confirmação de que as atividades complementares, relativas a tal período, já tenham sido ou não registradas pelos educadores. As 100 horas de atividades complementares são divididas igualmente entre os componentes curriculares. 
Nesse caso, o professor a mais se caracteriza num dinamizador do processo de ensinoaprendizagem, não assumindo, especificamente, nenhum componente curricular, mas sim, dinamizando os 08 (oito) componentes curriculares. Possibilita aos professores um período de estudo, planejamento e pesquisa e envolve-se no planejamento e desenvolvimento das atividades complementares. Contribui no desenvolvimento de projetos interdisciplinares, culturais e outros.

Nas escolas em que o quantitativo de turmas da EAJA de $1^{\text {a }}$ à $8^{\mathrm{a}}$ série totalizar 04 (quatro) ou mais turmas, é modulado o Professor Coordenador, com a carga horária de 30h semanais.

\section{Educação Fundamental de Adolescentes, Jovens e Adultos de $5^{a}$ à $8^{a}$ série - Base Curricular Paritária - Organização Alternativa}

11. Carga horária: 200 dias letivos e 800 horas, assim distribuídas: 600 horas presenciais de efetivo trabalho em horário letivo seja dentro ou fora da escola, com a presença do educador e educando; 200 horas complementares por meio de trabalhos desenvolvidos fora do horário letivo pelo educando. Todos os componentes curriculares possuem a mesma carga horária anual.

12. Jornada letiva: $3 \mathrm{~h}$ diárias

13. Componentes Curriculares:Língua Portuguesa, Educação Física, Artes, Ciências, Geografia, História, Matemática e Língua Estrangeira Moderna (Inglês), organizados em cinco áreas de conhecimento, assumidas, cada uma, por um professor.

- Comunicação - Língua Portuguesa e Língua Estrangeira Moderna

- Desenvolvimento Lógico - Matemática

- Ciências Naturais - Ciências (Físicas, Químicas e Biológicas).

- Jogos e Expressão - Educação Física e Artes

- Ciências Sócio-Ambientais - Geografia História

- Atendimento de grupos com 2 ou 3 turmas em Unidades Escolares ou extensões. As escolas com duas turmas e próximas devem ser agrupadas e o coletivo passa a ter 06 (seis) profissionais

- Registro de avaliação realizado, trimestralmente, de forma descritiva

Na Organização Alternativa, é papel dos professores que assumem atividades de um outro componente curricular para viabilizar a equidade na carga horária, integração do coletivo e 
momentos de formação do professor titular, planejar, em parceria com este, o trabalho a ser desenvolvido, fazer os estudos necessários para o seu desempenho relatar, posteriormente, as dificuldades e avanços do processo vivido. Nessas atividades, o princípio da interdisciplinaridade é de grande relevância, pois, fazendo as relações entre os conhecimentos, podemos garantir significado aos mesmos.

\section{3- Referências}

ANTUNES, Irandé. Aula de Português / encontro \& interação. São Paulo: Parábola Editorial, 2003.

ALMEIDA FILHO, J. C. P. de. Dimensões comunicativas no ensino de línguas. Campinas, São Paulo: Pontes, 2002.

ALMEIDA, Andrea Silvânia de. Interfaces metodológicas da Educação Física críticoemancipatória. Artigo publicado na revista HISTEDBR On-line, n 30, p. 27-38, jun. 2008 ISSN: 1676-2584. Disponível em: www.histedbr.fae.unicamp.br/revista/edicoes/30/art03_30.pdf. Acessado em: 15/08/09.

ALVES-MAZZOTTI, A. J. O método nas ciências sociais, In: ALVES-MAZZOTTI, A. J.;

ANTUNES, Irandé. Aula de Português / encontro \& interação. São Paulo: Parábola Editorial, 2003.

AUAREK, Wagner A. A superioridade da matemática escolar: um estudo dasrepresentações deste saber no cotidiano da escola. Belo Horizonte: UniversidadeFederal de Minas Gerais, 2000. (Dissertação, Mestrado em Educação)

BARBOSA, Ana Mae. A imagem no ensino da arte: anos oitenta e novos tempos. 4. ed. São Paulo: Editora Perspectiva, 1999.

BAKHTIN, Mikhail: Marxismo e filosofia da linguagem. 3 ed. São Paulo: Hucitec, 1988.

Os gêneros do discurso. In: Estética da criação verbal. Trad. Maria Ermantina G. G. Pereira. São Paulo: Martins Fontes, 1997.

BEZERRA, Maria Auxiliadora; DIONÍSIO, Ângela Paiva; MACHADO, Anna Rachel.Gêneros Textuais \& Ensino. Rio de Janeiro: Lucerna, 2002.

BRACH, Valter et.al. Coletivo de Autores: Metodologia do Ensino de Educação Física. São Paulo: Cortez, 1992.

BRASIL: MEC Proposta curricular de Educação Física para o segundo segmento. vol.3. Disponível http://portal.mec.gov.br/secad/arquivos/pdf/eja/propostacurricular/segundosegmento/vol3 edu 
fisica.pdf. Acessado em 21/08/2006.

SOARES, Carmem Lúcia. Educação Física: raízes européias e Brasil. Campinas: Autores Associados, 1994.

BRASIL. Constituição (1998). Constituição da República Federativa do Brasil, DF : Senado, 1988.

BRASIL. Parâmetros Curriculares Nacionais para o Ensino Fundamental: Língua Estrangeira. Brasília: MEC/ SEF, 1998.

BELLONI, Maria Luiza. Tecnologia e formação de professores: Rumo a uma pedagogia pósmoderna?. Educ. Soc., Campinas, v. 19, n. 65,dez. 1998 .Disponível em $<$ http://www.scielo.br/scielo.php?script=sci_arttext\&pid=S0101-

73301998000400005\&lng=pt\&nrm=iso $>$. acessos em06 ago. 2009. doi: 10.1590/S010173301998000400005 .

BEZERRA, Maria Auxiliadora; DIONÍSIO, Ângela Paiva; MACHADO, Anna Rachel.Gêneros Textuais \& Ensino. Rio de Janeiro: Lucerna, 2002.

BRASIL. Ministério da Educação. Educação para Jovens e Adultos: Ensino Fundamental: Proposta Curricular: Primeiro Segmento [RIBEIRO, V. M. M.-coord.]. São Paulo: Ação Educativa/MEC. 2001.

Secretaria de Educação Fundamental. Proposta Curricular para a educação de jovens e adultos: segundo segmento do ensino fundamental: $5^{\mathrm{a}}$ a $8^{\mathrm{a}}$ série : introdução / Secretaria de Educação Fundamenta

. Constituição da República Federativa do Brasil. Diário Oficial [da] República Federativa do Brasil, Brasília, 05 de outubro de 1988.

Conselho Nacional de Educação (CNE). Câmara de Educação Básica (CEB). Parecer no 11, de 7 de junho de 2000. Diretrizes Curriculares Nacionais para a Educação de Jovens e Adultos. Brasília, 2000

Lei no 9394, de 20 de dezembro de 1996 de Diretrizes e Bases da Educação Nacional. Diário Oficial [da] República Federativa do Brasil, Brasília, 23 de dezembro de 1996.

2002.

. Diretrizes Curriculares Nacionais da Educação de Jovens e Adultos. Brasília,

. Proposta Curricular para a Educação de Jovens e Adultos: Segundo Segmento do Ensino Fundamental. Brasília: MEC/SEF, 2002.

BLOCH, Marc.introdução à história. Lisboa: Europa América, 1997.

BOAS, Benigna $\mathrm{M}^{\mathrm{a}}$. De Freitas Villas. O projeto político-pedagógico e avaliação. 
In. VEIGA, Ilma Passos A. (org). ESCOLA - espaço do projeto político-pedagógico. Campinas SP: Papirus, 1998.

CARVALHO, Marlene. Alfabetizar e letrar: um diálogo entre a teoria e a prática. Petrópolis: Vozes. 2005.

CENTRO DE AÇÃO COMUNITÁRIA. Educação de Jovens e Adultos - CEDAC. Que alfabetização desejamos? In. Saberes: Alfabetização de pescadores artesanais. Informações, reflexões e pistas metodológicas na formação de educadores. Ed. Especial. Brasília, DF. MAPA, 2005. (p.20-27).

COSTA, Cláudia B. O trabalhador-aluno da Eaja: desafios no processo ensino-aprendizagem, 2008. Dissertação (mestrado).

COSTA, Sílvio. O trabalho como elemento fundante da humanização: texto publicado na Revista Estudos. Universidade Católica de Goiás. v. 22, n.3/5, dez. 1996, p. 171-188.

CAMILO, C. H.. Cultura e Arte na dança para deficientes.In: $3^{\circ}$ Congresso Estadual de Educação Física de Goiás, 1999, Goiânia-GO.

CAMPOS, Anderson José Moura de. Educação Física e o conceito de cultura: o corpo no tempo, espaço e ciberespaço. Disponível em: http://www.semebrusque.com.br/downloads/2007/educacao_fisica_e_o_conceito_de_cultura_oficializado.pdf. Acessado em: 22/08/09.

CARVALHO, Marlene. Alfabetizar e letrar: um diálogo entre a teoria e a prática. Petrópolis: Vozes. 2005.

CAVAlCANTE, Lana de Souza. Geografia, Escola e Construção de Conhecimentos. Campinas , SP. Papirus, 1998.

2002. Geografias e práticas de ensino. Goiânia. Alternativa,

DAMIANI, Amélia Souza. O lugar e a produção do cotidiano. In: CARLOS, A.F.A. (org). Novos Caminhos da Geografia. SP. Contexto, 1999.

DAOLIO, Jocimar. Educação Física e ciência humanas. Revista Movimento e Percepção, v. 1, n.3, p.13-21.

DURKHEIM,Emily. As formas elementares da vida religiosa. São Paulo: Paulinas, 1989.

FÁVERO, Leonor Lopes. Oralidade e escrita: perspectivas para o ensino de língua materna. São Paulo: Cortez, 2002.

Leonor L; KOCH, Ingedore V. Lingüística textual. São Paulo: Cortez, 1983.

FONSECA, Maria da Conceição F. R. (org.) A educação matemática e a ampliação das demandas de leitura e escrita da população brasileira. In: Letramento no Brasil: Habilidades 
Matemáticas. São Paulo: Global: Ação Educativa Assessoria, Pesquisa e Informação: Instituto Paulo Montenegro, 2004, p. 11-28.

FLEURI, Reinaldo Matias. Políticas da diferença: para além dos estereótipos na prática educacional. Revista Educ. Soc., Campinas, vol. 27, n. 95, p. 495-520, maio/ago. 2006. Disponível em $<$ http://www.cedes.unicamp.br

FROCHTENGARTEN, Fernando.Caminhando sobre fronteiras: O papel da educação na vida de adultos migrantes. São Paulo: Summus, 2009.

FEITOSA, Sonia Couto Souza. "Método Paulo Freire: princípios e práticas de uma concepção popular de educação", (Dissertação de Mestrado) - Curso de Pós-graduação em Educação, Universidade de São Paulo, 1999 Disponível em: <http://www.paulofreire.org/twiki/pub/Crpf/CrpfAcervo000077/Dissertacao_de_mestrado_So nia.pdf

FUSARI, José Cerchi. A Construção da Proposta Educacional e do Trabalho Coletivo na Unidade Escolar. Disponivel em: http://www.crmariocovas.sp.gov.br/pdf/ideias_16_p069$\underline{077 \text { c.pdf }}$

FERREIRO, Emilia. Psicogênese da Língua Escrita. Porto Alegre: Artes Médicas, 1999. Alfabetização em Processo. São Paulo: Cortez, 1986.

FÁVERO, Leonor L; KOCH, Ingedore V. Lingüística textual. São Paulo: Cortez, 1983.

Leonor Lopes. Oralidade e escrita: perspectivas para o ensino de língua materna. São Paulo: Cortez, 2002.

FOUCAULT, Michael. Microfísica do Poder. Rio de Janeiro, Graal, 1979.

FARIA, Juliana Batista. Um estudo das possibilidades da Educação Matemática Escolar de Jovens e Adultos na perspectiva do numeramento.GEN/FAE/UFMG., $\mathrm{N}^{\circ} 18$.

FREIRE, Paulo. Política e educação: ensaios. São Paulo: Cortez, 1995.

. Pedagogia do oprimido. 20a ed. Rio de Janeiro: Paz e Terra, 1987.

Pedagogia da Esperança: um encontro com a pedagogia do oprimido. Rio de Jeiro: Paz e Terra, 1994, p. 83 a 136.

. A importância do ato de ler. 39ed. São Paulo: Cortez, 2000.

. Educação como prática da liberdade. 17ª ed. Rio de Janeiro: Paz e Terra, 1986.

e Terra, 2004.

Pedagogia da autonomia: saberes necessários à prática educativa. São Paulo: Paz . Educação e mudança. 28. ed. Rio de Janeiro: Paz e Terra, 1979.

. Conscientização: teoria e prática da libertação uma introdução ao pensamento de 
Paulo Freire. São Paulo: Cortez \& Moraes, 1980.

A educação na cidade. São Paulo: Cortez, 2001.

FUNAI. Museu do índio. Disponível em: http://base2.museudoindio.gov.br/cgibin/wxis.exe?IsisScript=phl.xis\&cipar=phl81.cip\&lang=por. Acesso em: 22 de setembro de 2003.

GEWANDSZNAJDER, Fernando. O método nas ciências naturais e sociais: pesquisa quantitativa e qualitativa. São Paulo: Pioneira Thomson Learning, 2002.GOMBRICH, E. H. A História da Arte. Rio de Janeiro: LTC, 1999.

GOMES, Nilma Lino. Cultura negra e educação. Revista Brasileira de Educação. n. 23. Rio de

Janeiro maio/ago. 2003.

GOMES, Cleomar Ferreira. Corporeidade e Ludicidade: Estudos sobre conteúdos trabalhados por professores de Educação Física na Rede Cuiabana. Projeto de Pesquisa: Cuiabá, 2004.

GONÇALVES, Maria Augusta Salin. Sentir, Pensar, Agir, Corporeidade e Educação. Campinas: Papirus, 1994.

GORINI, Maria Augusta Geabra \& SOUZA, Nadia Aparecida. Avaliação da aprendizagem: a construção de uma proposta em Educação Física. Revista Estudos em avaliação educacional, v.18, n.36, jan./abr., 2007.

GERALDI, João Wanderley. O texto na sala de aula. São Paulo: Editora Ática, 2003.

GOIÂNIA. Secretaria Municipal de Educação. Aconstrução de uma proposta de educação para adolescente, jovens e adultos, pelo sujeitos do processo educativo, 2004.

HALL, Stuart. A Identidade cultural na pos-modernidade. Trad. Tomaz T. Silva. , Rio de Janeiro, Ed. DP\&A, 2001.

HADDAD, Sergio; DI PIERRO, Maria Clara. Escolarização de Jovens e Adultos. In.: Revista Brasileira de Educação: 500 anos de educação escolar. São Paulo: Cortez, n. 14, maioago.2000.

HENRIQUES, Cláudio Cezar; PEREIRA, Maria Teresa Gonçalves (orgs.). Língua e Transdisciplinaridade, rumos, conexões, sentidos. São Paulo: Contexto, 2002.

HOFFMANN, Jussara. M. Lerch. Contos e contrapontos: do pensar ao agir em avaliação. Porto Alegre: Mediação, 1998. cap. 1, p. 12 a 32.

KLEIMAN, Ângela B; MORAES, Silvia. Leitura e interdisciplinaridade: tecendo redes no projeto da escola. Campinas: Mercado de Letras, 1999.

KISHIMOTO, Tizuko M.. O jogo e a educação infantil. In. KISHIMOTO, Tizuko M. (Org.). Jogo, brinquedo, brincadeira e a educação. $3^{\text {a }}$ ed. São Paulo: Cortez, 1999. 
KUNZ, Eleonor. Transformação didático-pedagógica do esporte. Ijuí, Unujuí, 1994.

LEFFA, Vilson J. Metodologia do ensino de línguas. In BOHN, H. I.; VANDRESEN, P. Tópicos em lingüística aplicada: O ensino de línguas estrangeiras. Florianópolis: Ed. da UFSC, 1988. p. 211-236.

LACOSTE, Yves. A Geografia - Isso serve em primeiro lugar para fazer a guerra. Trad. Maria Cecília França. Campinas SP. Papirus, 1988.

MOREIRA, Ruy. Para Onde vai o pensamento geográfico? SP. Contexto, 2006.

MAUSS, M. As Técnicas Corporais. In: Sociologia e Antropologia, com uma introdução à obra de Marcel Mauss, de Claude Lévi-Strauss; Volume II - tradução de Lamberto Puccinelli. São Paulo: EPU, 1974. (p.211-233).

MACEDO, B.; KATZKOWICZ, R. Educação Científica: Sim, mas qual e como? In Cultura Científica, Brasília:UNESCO, 2003.

MARCONDES, Maria I. Currículo de formação de professores e prática reflexiva: possibilidades e limitações.Políticas organizativas e curriculares, educação inclusiva e formação de professores -[ Dalva E. Gonçalves Rosa, Vanilto Camilo de Souza]; Alfredo Veiga Neto...[et. al.]. - Rio de Janeiro: DP\&A, 2002.

MENEZES, Cristiane de S. As relações de gênero no processo de escolarização de alunas da Educação de Jovens e Adultos. Disponível em: <http://www.fundaj.gov.br/licitacao/relacaodegenero.pdf> Acesso em: 7 ago. 2009, p. 1 - 21.

MIRANDA, Sônia R. O que significa educar para a compreensão da História? Um olhar a partir de um programa de avaliação educacional. Londrina: Revista História \& Ensino, n 09 , outubro de 2003.

MOREIRA, Antônio Flávio Barbosa \& CANDAU, Vera Maria. Currículo, Conhecimento e Cultura. Disponível em: <http://portal.mec.gov.br/seb/arquivo/pdf/Ensfund/indag3.pdf.> Acesso em: 19 nov. 2008, p. 17-48.

MORIN, Edgar. A cabeça bem-feita. $8^{\text {a }}$ Ed. Tradução Eloá Jacobina. Rio de Janeiro: Bertrand Brasil, 2003.

NOSELLA, Paolo. A Escola Brasileira no final do século: um balanço in Educação e crise no trabalho: perspectivas de final de século. Gaudêncio Frigotto (org.) - Petrópolis, RJ: Vozes, 1998 (Coleção Estudos Culturais em Educação).

NOGUEIRA, Adriano. Que fazer - teoria e Prática em Educação Popular. 5 ed.Petrópolis: Vozes, 1999.

NÓVOA, Antônio. Os Professores na Virada do Milênio: do excesso dos discursos à pobreza das práticas. Revista Educação e Pesquisa, v. 25, n. 1. São Paulo, jan/jun, 1999.

OLIVEIRA, Cacilda Lages. Significado e contribuições da afetividade no contexto da 
metodologia de projetos na educação básica. Dissertação de mestrado, CEFET-MG, 2006.

OLIVEIRA, Khol Marta. Jovens e adultos como sujeitos de conhecimento e aprendizagem. In. Revista Brasileira de Educação, no 12. São Paulo, dez./1999, e, In. Educação de jovens e adultos: novos leitores, novas leituras. Org. Vera Marzagão Ribeiro. Campinas, SP: Mercado de Letras: Associação de Leitura do Brasil - ALB; São Paulo: Ação Educativa, 2001.

Paulo. Scipione, 2002.

Vygotsky-Aprendizado e desenvolvimento um processo sócio-histórico. São . Investigações cognitivas: conceitos, linguagem e cultura. . Porto Alegre / RS: Artes Médicas, 1999.

, Marta Kohl de. Vygotsky-Aprendizado e desenvolvimento um processo sóciohistórico. São Paulo. Scipione, 2002.

PARÂMETROS Curriculares Nacionais de Língua Portuguesa. Brasília: MEC/Secretaria de Educação Fundamental, 1998.

PARANÁ. Secretaria de Estado da Educação. Documento Síntese. Programa de Desenvolvimento Educacional - PDE, 2007.

PINHEIRO, Rosa Aparecida. Formação de educadores de jovens e adultos: saberes na proposição curricular. $31^{a}$ Reunião Anual. Disponível em : http//www.Anped.org.br >.Acesso em 06 ago. 2009.

PINSK, Jaime; PINSK, Carla B. Por uma história prazerosa e consequente. In. KARNAL, Leandro (org.). História na sala de aula, conceitos, práticas e propostas. São Paulo: Contexto, 2007.

ROJO, Roxane (org.). A prática de linguagem em sala de aula: praticando os PCNs. São Paulo/Campinas: EDUC/Mercado de Letra, 2000.

RIBEIRO, Vera Masagão (coord.). Educação de Jovens e Adultos: proposta curricular para o primeiro segmento do ensino fundamental. São Paulo: Ação Educativa; Brasília: MEC, 1997.

RODRIGUES, Maria Emília de Castro.Tema Gerador. Texto mimeo.Produzido em 22/11/2003 para o retorno dos dados da pesquisa: A Construção de uma Proposta Democrática Popular de Educação para Adolescentes, Jovens e Adultos da Rede Municipal de Eduação de Goiânia, pelos sujeitos do processo educativo, às unidades Escolares.

RESENDE, Márcia Spyer. A geografia do aluno trabalhador. Caminhos para uma prática de ensino. SP. Loyola, 1989.

SANTOS, Esmeraldina Maria dos. Os saberes dos professores do ensino fundamental da educação de adolescentes, jovens e adultos. Goiânia: Universidade Católica de Goiás, Dissertação de mestrado, 2007.

SCHNEUWLY, Bernard; DOLZ, Joaquim; e colaboradores. Gêneros orais e escritos na escola. Trad. E org. Roxane Rojo e Glaís Cordeiro. Campinas: Mercado de Letras, 2004. 
SCANDIUZZI, Pedro Paulo.

SANTOS, Milton. O Espaço do Cidadão. SP. Nobel, 2000.

Por uma outra globalização. RJ. Record, 2008.

SILVA, Ivonete Maria da. "OU TRABALHA E COME OU FICA COM FOME E ESTUDA:" o trabalho e a não-permanência de adolescentes, jovens e adultos na escola em Goiânia. Goiânia: UFG, dissertação de mestrado, 2004.

SILVA, Raquel de Almeida. A mulher na EJA - Uma análise da 'diferença' na Educação de Jovens E Adultos do Município do Rio De Janeiro. Disponível em: $<$ http://www.fazendogenero7.ufsc.br/artigos/R/Raquel_de_Almeida_Silva_58.pdf $>$ Acesso em: 7 ago. 2009, p. 1-7.

SILVA, Antonio Ferndo Gouvêa. Cadernos Pedagógicos. Secretaria Municipal de Educação, Maceió, 2001.

SILVA, de Melo Aguiar. Matemática e educação matemática: re (construção) dos sentidos com base na representação social.

SILVA, L.H. A.; SCHNETZLER, R.P. Buscando o caminho do meio: a "sala de espelhos" na construção de parcerias entre professores e formadores de professores de ciências. Revista Ciências \& Educação, v.6, n.1, p.43-53, 2000.

SOARES, Magda B. Letramento: um tema em três gêneros. Belo Horizonte: Autêntica, 2001.

. Letramento e escolarização. In: RIBEIRO, Vera Masagão (org.). Letramento no Brasil: reflexões a partir do INAF 2001. 2 ed. São Paulo: Global, 2004, p. 89-113.

SCHNEUWLY, Bernard; DOLZ, Joaquim; e colaboradores. Gêneros orais e escritos na escola. Trad. E org. Roxane Rojo e Glaís Cordeiro. Campinas: Mercado de Letras, 2004.

SPOSITO, Marilia Ponte. Juventude: crise, identidade e escola in DAYRELL, Juarez. Múltiplos olhares sobre a educação e cultura. Belo Horizonte. Editora UFMG, 1996.

TAFFAREL, Celi Nelza. Criatividade nas aulas de Educação Física. Rio de Janeiro: Ao Livro Técnico, 1985.

TOLEDO, Maria Elena R. de O. As estratégias metacognitivas de pensamento e o registro matemático de adultos pouco escolarizados. Tese (Doutorado). Faculdade de Educação, USP, São Paulo, 2003.

VÓVIO, Cláudia L. e BICAS, Marilene de S. Formação de educadores: aprendendo com a experiência. Construção coletiva: contribuições à educação de Jovens e adultos - Brasília: UNESCO, MEC, RAAAB, 2008,p. 201-211. (Coleção educação para todos;3).

VYGOTSKY, L. S. A construção do pensamento e da linguagem. São Paulo. Martins Fontes, 2001. 
VALENTE, Edison Francisco \& ALMEIDA FILHO, Japson Macedo. História da Educação Física, esporte, dança e lazer. Disponível em: http://www.atlasesportebrasil.org.br/textos/297.pdf. Acessado em: 28/09/09.

VIEIRA, Evaldo. Democracia e Política Social. São Paulo: Cortez, 1992.

WOSIEN, Bernhard. Dança: um caminho para a totalidade. São Paulo: Triom, 2000. 


\section{PROJETO DE INTERVENÇÃO LOCAL (PIL): RELATÓRIO DE EXPERIÊNCIA}

A reflexão e a prática da Construção Coletiva do conhecimento, da aprendizagem e a ampliação de uma rede colaborativa é fundamental para as transformações necessárias na educação frente a novas tecnologias.

Foi neste intuito de formação continuada e permanente de uma Comunidade de Trabalho/Aprendizagem em Rede, que elaboramos o PIL. Este ativismo em rede, ou seja, os diálogos nos fóruns, os encontros presenciais, os visionamentos de vídeos, a leitura de vários textos sobre diferentes temáticas e a socialização com colegas, professores e tutores responsáveis foram qualitativos nos estudos e debates durante os módulos, pedagogicamente elaborados, para o Curso de Especialização em Educação na Diversidade e Cidadania.

As aprendizagens ocorridas no decorrer do per-curso, o caminho percorrido permitiu um entendimento de onde se partiu e aonde se quer chegar. No acesso ao ambiente de aprendizagem não encontramos dificuldades, todavia algumas causalidades ocorreram interferindo na administração do tempo. Os textos indicados auxiliaram e articularam com os tópicos solicitados favorecendo uma melhor compreensão dos temas abordados, principalmente para o mundo do trabalho.

Acompanhamos e orientamos algumas escolas da EAJA no estudo e discussões da Proposta Político Pedagógica no período de 27 de outubro a 13 de novembro de 2009 com o objetivo de contribuir com o trabalho pedagógico na EAJA. No mesmo período na Unidade Regional Jarbas/Jayme o proponente, Rafael, juntamente com os apoios pedagógicos que acompanham as escolas da EAJA realizaram um estudo sistemático da referida proposta. Nos estudos dos referidos apoios ocorreram à leitura detalhada do documento com o objetivo de corroborar por meio da análise e sugestões. Dessa forma foi realizada supressão, substitutivo ou aditivo na concepção e estrutura da proposta.

No dia 17 de novembro ocorreu a reunião na URE/JARBAS JAYME com os representantes das escolas, da DEF-AJA e do Centro de Formação. A pauta da reunião foi à socialização da avaliação da Proposta Preliminar da EAJA/2009. Os organizadores retomaram os elementos que subsidiaram a avaliação da Proposta Político-Pedagógica, depois ocorreu à atividade em grupo. A plenária foi rica em debate e intervenções.

$\mathrm{Na}$ contextualização dos relatórios de acompanhamento nas escolas acerca das ações desenvolvidas pelos os apoios pedagógicos da EAJA constaram às orientações da implementação da proposta (exemplo de relatório em anexo). Durante o primeiro semestre de 2010 os apoios da URE Jarbas Jayme analisaram a segunda devolutiva dos P.P.Ps das escolas e verificaram que são raras as escolas que constam o estudo para implementação da proposta da Rede. Aquelas escolas que incluíram o estudo da referida proposta 
apresentou de forma sucinta, ou seja, somente fica no campo da socialização da proposta e não do aprofundamento e materialização para ressignificar a prática pedagógica. Entretanto nos P.P.Ps verificou a consonância com a P.P.P da rede em relação a aplicação do diagnóstico, o currículo e as especificidades dos sujeitos da EAJA. Constatamos que nos P.P.Ps e na prática pedagógica das escolas não tiveram uma discussão reflexiva sobre o mundo do trabalho e o sujeito trabalhador, ou seja, reflexões acerca de um currículo voltado para o trabalhador de forma integral, ficando restrito a metodologia de ensino,pois a Proposta da Rede não aponta para o currículo integrado como faz o PROEJA. Observamos que as escolas realizam na prática oficinas pedagógicas voltadas para o trabalho, identificam que o educando é trabalhador (diagnósticos perfil socioeconômico), mas não há um embasamento teórico da temática o mundo trabalho na realidade das escolas Municipais de Goiânia. De acordo com Libâneo (2009, p.119) "A formação para a cidadania crítica e participativa diz respeito a cidadãos-trabalhadores capazes de interferir criticamente na realidade para transformá-la, e não apenas para integrar o mercado de trabalho".

Os apoios pedagógicos da URE Jarbas Jayme reuniram dois dias (19 e 20 de abril de 2010) com os coordenadores pedagógicos da EAJA para proceder algumas orientações relevantes ao trabalho pedagógico na EAJA. (em anexo o relatório de acompanhamento). $\mathrm{Na}$ oportunidade leram e discutiram sobre o texto AVALIAÇÃO, elaborado pela URE Jarbas, para subsidiar a discussão e estudo do coletivo de professores sobre o processo avaliativo. Pontuaram ainda sobre a necessidade de estudo da PPP da EAJA (RME), com enfoque na Concepção de Avaliação da EAJA, diferenciando Classificação de Avaliação.

Outra problemática é a migração dos educandos do Ciclo para EAJA ocorrendo o Fenômeno de juvenilização da EAJA. Outro fator os pais/responsáveis dos educandos do Ciclo são na maioria não alfabetizados, ou seja, não leem os registros de aprendizagens dos educandos. Outro motivo para pensar em uma política pública que torne o currículo da EAJA integrado e garanta no mínimo a alfabetização desses pais incluindo-os a sua realidade social e ao mundo do trabalho. Falar de mundo do trabalho e associar ao mercado de trabalho formal e informal, por isso os educandos deverão ser emancipados para a Educação do conhecimento e da informação para que sejam inclusos no Mundo tecnológico.

Diante desta situação é interessante propor um seminário na Rede Municipal de Goiânia e convidar os professores do curso de especialização em Educação na Diversidade e Cidadania, com ênfase na EJA pela Universidade de Brasília (UnB) no âmbito da Universidade Aberta do Brasil (UAB) para irem fazer um debate como forma de sensibilizar e conscientizar os gestores para construção de referenciais que considere a confluência das especificidades da formação profissional inicial e da segunda fase do ensino fundamental EAJA. Tendo articulação da Proposta Pedagógica da EAJA com o documento Base PROEJA Formação Inicial e Continuada - Ensino (2007) e o relato de experiência com a implantação 
e realização desse Programa na Rede Municipal de Educação de Goiânia no decorrente ano de 2010

A concepção de educação do Proeja é uma concepção de educação continuada de cunho profissional, para além da Educação Básica, que rompe com a dualidade cultura geral versus cultura técnica, a primeira, educação academicista, destinada aos filhos das classes mais favorecidas socioeconomicamente e a segunda, educação instrumental voltada para o trabalho, destinada aos filhos da classe trabalhadora. $O$ objetivo da formação fundamenta-se na integração ente trabalho, ciência, tecnologia, humanismo e cultura geral, contribuindo para o enriquecimento científico, cultural, político e profissional dos sujeitos atendidos pelo programa, através da indissociabilidade dessas dimensões no mundo real, estreitamente vinculadas às condições necessárias ao efetivo exercício da cidadania. (SILVA, 2009, p.41).

Desse modo, pensamos que a partir das temáticas estudadas no módulo IV como: Educação Ambiental na prática educacional, Educação para o reconhecimento do Gênero e a Diversidade Sexual, Educação das Relações Étnico-Raciais, Educação Especial na perspectiva da Educação Inclusiva. Essas temáticas são todas relevantes para contribuir com a Proposta Pedagógica da EAJA.

As questões da Educação das relações Etnicorraciais, estão constantemente ligadas na escola ao currículo oculto que promove a violência simbólica. Nós educadores devemos relacionar com um diálogo democrático que oportunize o debate, a troca de idéias e experiências. O negro discriminado historicamente, atualmente luta pelos direitos de cidadania.

Refletir em Educação é dialogar com a sociedade em uma realidade concreta. Penso no tema da inclusão como um debate polêmico, pois pesquisas mostram que na realidade escolar ocorre o processo de integração em vez do processo de inclusão. Incluir é mais que integrar e socializar, ou seja, é dar oportunidade ao educando a possibilidade da aprendizagem reconhecendo seu limite de desenvolvimento. Verificamos a verticalização da inclusão e as faltas de investimentos com os profissionais da educação. Responsabilizamos os professores e criticamos pouco a falta de programa ou projeto de intervenção que atendesse a necessidade escolar. Pensamos em uma literatura romântica da inclusão e esquecemos a realidade concreta que nosso próprio sistema educacional proporciona, gerando assim a violência simbólica dentro do currículo oculto.

Compreendemos no texto que define sobre gênero que homens e mulheres são produtos da realidade social e não decorrência da anatomia de seus corpos. Assim podemos verificar ao longo da história a luta de várias mulheres pela conquista de emancipação e luta pelos direitos humanos de igualdade e participação na construção da sociedade voltada para o mundo do trabalho.

A leitura do texto que aborda o Tratado de educação ambiental para sociedades 
sustentáveis e responsabilidade global é um ponto de partida para ressignificar o currículo da EAJA. Em um dos princípios que pontua que a educação ambiental deve envolver uma perspectiva holística, enfocando a relação entre o ser humano, a natureza e o universo de forma interdisciplinar. Esse enfoque pedagógico dentro da proposta da EAJA deverá ser trabalhado de forma interdisciplinar com objetivo de transformar os atos e as ações dos sujeitos com o Meio Ambiente.

No texto políticas integradas e visão sistêmica diferencia o conceito sociedades sustentáveis de desenvolvimento sustentável. O primeiro deverá ser enfatizado em qualquer proposta pedagógica de EAJA, pois inclui uma visão transformadora, apoiada na diversidade de buscas e soluções para a construção simultânea e coletiva das sustentabilidades ambiental, social, econômica, política e ética.

Penso que na elaboração de uma proposta de Educação Ambiental a comunidade escolar priorize as necessidades e os problemas ocasionados em seu meio social, pois pelo diagnóstico da realidade e com professores que articule e aproprie do conhecimento poderá mediar informação e formará sujeitos emancipados e conscientizados de sua prática ambiental e laboral.

No visionamento do documentário "HISTÓRIAS DE UM BRASIL ALFABETIZADO" retrata situações limites em que se dá o processo de alfabetização de jovens e adultos. Em 72 minutos, são apresentados os desafios de cinco personagens, Jovens de periferia, quilombolas, empregadas domésticas, cortadores de cana, professores, catadores de lixo histórias de vida que formam um mosaico rico e diverso sobre o ato de aprender a ler e escrever.

No visionamento do documentário aumentou nossa ideologia e incentivo de pesquisar e contribuir para a Realidade da EAJA, tanto na P.P.P da RME como em intervenção local. Questionamentos poderão ser feitos quantos a nossos educandos trabalhadores. Qual o tipo de trabalho que predomina da cidade de Goiânia? Os adolescentes qual capacitação deverão ter para atualizar no mundo do trabalho atual? O currículo deverá ser integrado? $\mathrm{O}$ PROEJA FIC poderá ser o ponto de partida para ressignificar a Proposta Político Pedagógico da EAJA.

A construção de um projeto integrado é posta como o grande desafio do Proeja, mas, como existe a possibilidade da oferta de forma concomitante, a orientação é que se construa um Projeto Político-Pedagógico único, em que a concomitância ocorra desde o início do curso, como uma estratégia para se aproximar da oferta integrada. É sugerido ainda que se incorporem nesse projeto as concepções e os princípios da proposta de oferta integrada. A premissa de possibilidade de avançar na construção de uma formação integrada se dá por conceber que a formação não é resultado somente de um tipo de currículo implementado; antes, carrega traços de opções feitas pelo Estado, pela gestão local, pela prática do trabalhador da educação, pela relação em sala de aula e, dentre outras, de opções feitas pelo indivíduo educando durante sua vida. (CAMPOS, 2010, p.56) 
A articulação da EAJA com os movimentos sociais, educacionais e políticos são relevantes para que as experiências de implantação e implementação do PROEJA-FIC (Formação Inicial e Continuada), não fique meramente na tautologia para o atendimento exclusivo ás necessidades do mercado.

O PROEJA - Formação Inicial e Continuada - Ensino Fundamental - tem como objetivo integrar conhecimentos da educação geral com a formação profissional inicial e continuada por meio de metodologias adequadas aos tempos e espaços da realidade dos sujeitos sociais que constituem 0 público beneficiário. (BRASIL, 2007, p.31).

Em nossas considerações finais recorremos às discussões realizadas pela professora Maria Margarida Machado (2007). Penso que a estratégia para unirmos coerentemente nos fóruns, nas secretarias de educação, nas organizações docentes e discentes, nos debates políticos, etc. É concentrar e encaminhar nossas ações e reflexões no Ministério da Educação, DEJA, Secad, conforme Machado (2007) "é nele que deve se concentrar o poder de força em defesa da educação como direito para todos. Para isso enfatizamos nossa força na construção coletiva da política de EJA em uma perspectiva freireana sem interesses partidários." O objetivo nessas organizações é a luta de ampliar matrículas na EJA, facilitar o acesso e reconhecer as especificidades dos educandos trabalhadores da EJA. Reportando a realidade da Cidade de Goiânia na modalidade EAJA (Educação de Adolescentes, Jovens e Adultos) os gestores, professores, comunidades escolares deverão buscar melhor financiamento do Fundeb para essa modalidade, realizar parceria, principalmente tendo o foco a Economia Solidária. Atualmente (2010) a SME tem buscado caminhos para ressignificar a EAJA por meio da reescrita da Proposta Político Pedagógica da EAJA. Nesse propósito como a P.P.P será implementada? Na realidade educacional a P.P.P contempla a relação entre escolarização e mercado/mundo do trabalho?

Nesse sentido, temos efetivar este Circulo de Cultura em combate a política do "pão e circo", da alienação e da opressão. Pensamos que partindo de uma reflexão rigorosa radical de conjunto, materializaremos a rigorosidade epistemológica de Paulo Freire com intervenção em uma dada realidade social. Assim, poderemos contribuir com o processo de emancipação dos educandos trabalhadores para o mundo do trabalho.

Portanto, o curso a distância por meio da internet, enquanto espaço social, proporcionou-nos possibilidades ampliadas e potencialidades a partir das conexões em rede para subsidiar a concepção da temática "trabalho" na perspectiva da construção de um currículo integrado para EAJA. 


\section{Referências:}

Campos, Camila Aparecida de. Os desafios da implementação do currículo integrado do Proeja em Rio Verde-Go . Dissertação (mestrado), Universidade Federal de Goiás, 2010. $139 \mathrm{f}$.

ANTUNES, Ricardo. A dialética do trabalho: escritos de Marx e Engels. São Paulo: Expressão Popular, 2004.

BRASIL. Documento Base. Programa Nacional de Integração da Educação Profissional com a Educação Básica na Modalidade de Educação de Jovens e Adultos: Formação Inicial e Continuada / Ensino Fundamenta Brasília: MEC/ SETEC, 2007. Disponível <http://portal.mec.gov.br/setec/arquivos/pdf2/proeja_medio.pdf> Acesso em 08 de abril de 2010

GOIÂNIA. Secretaria Municipal de Educação. Proposta Político Pedagógica para o Ensino Fundamental de Adolescentes, Jovens e Adultos da Rede Municipal de Goiânia 2009 (versão preliminar). Goiânia.

MACHADO, Maria Margarida. A atualidade do pensamento de Paulo Freire e as políticas de Educação de Jovens e Adultos. REVEJ@ - Revista de Educação de Jovens e Adultos, v. 1, n. 1, p. 1-117, dez. 2007.

SILVA, Deliane de Morais. A Experiência do Projovem : As condições financeiras para a viabilidade da EJA com formação profissional. Monografia (especialização), Instituto Federal de Educação, Ciências e Tecnologia de Goiás-IFG, Goiânia, 2009.

VIDEOGRAFIA: - Histórias de Um Brasil Alfabetizado - Documentário PDE/MEC. 